\title{
Lithologic distribution and geologic history of the Apollo 17 site: The record in soils and small rock particles from the highland massifs
}

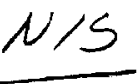

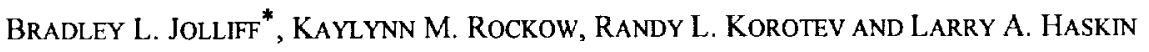 \\ Department of Earth and Planetary Sciences and McDonnell Center for the Space Sciences, \\ Washington University, St. Louis, Missouri 63130, USA \\ *Correspondence author's e-mail address: blj@levee.wustl.edu
}

(Received 1995 May 25; accepted in revised form 1995 October 23)

Abstract-Through analysis by instrumental neutron activation (INAA) of 789 individual lithic fragments from the $2 \mathrm{~mm}-4 \mathrm{~mm}$ grain-size fractions of five Apollo 17 soil samples $(72443,72503,73243,76283$, and 76503 ) and petrographic examination of a subset, we have determined the diversity and proportions of rock types recorded within soils from the highland massifs. The distribution of rock types at the site, as recorded by lithic fragments in the soils, is an alternative to the distribution inferred from the limited number of large rock samples. The compositions and proportions of $2 \mathrm{~mm}-4 \mathrm{~mm}$ fragments provide a bridge between compositions of $<1 \mathrm{~mm}$ fines and types and proportions of rocks observed in large collected breccias and their clasts. The $2 \mathrm{~mm}-4 \mathrm{~mm}$ fraction of soil from South Massif, represented by an unbiased set of lithic fragments from station-2 samples 72443 and 72503 , consists of $71 \%$ noritic impact-melt breccia, $7 \%$ incompatible-trace-element-(ITE)-poor highland rock types (mainly granulitic breccias), 19\% agglutinates and regolith breccias, $1 \%$ high-Ti mare basalt, and $2 \%$ others (very-low-Ti (VLT) basalt, monzogabbro breccia, and metal). In contrast, the $2 \mathrm{~mm}-4 \mathrm{~mm}$ fraction of a soil from the North Massif, represented by an unbiased set of lithic fragments from station-6 sample 76503, has a greater proportion of ITE-poor highland rock types and mare-basalt fragments: it consists of $29 \%$ ITE-poor highland rock types (mainly granulitic breccias and troctolitic anorthosite), 25\% impact-melt breccia, 13\% high-Ti mare basalt, $31 \%$ agglutinates and regolith breccias, $1 \%$ orange glass and related breccia, and $1 \%$ others. Based on a comparison of massweighted mean compositions of the lithic fragments with compositions of soil fines from all Apollo 17 highland stations, differences between the station- 2 and station- 6 samples are representative of differences between available samples from the two massifs.

From the distribution of different rock types and their compositions, we conclude the following: (1) North-Massif and South-Massif soil samples differ significantly in types and proportions of ITE-poor highland components and ITE-rich impact-melt-breccia components. These differences reflect crudely layered massifs and known local geology. The greater percentage of impact-melt breccia in the SouthMassif light-mantle soil stems from derivation of the light mantle from the top of the massif, which apparently is richer in noritic impact-melt breccia than are lower parts of the massifs. (2) At station 2, the $2 \mathrm{~mm}-4 \mathrm{~mm}$ grain-size fraction is enriched in impact-melt breccias compared to the $<1 \mathrm{~mm}$ fraction, suggesting that the $<1 \mathrm{~mm}$ fraction within the light mantle has a greater proportion of lithologies such as granulitic breccias which are more prevalent lower in the massifs and which we infer to be older (pre-basin) highland components. (3) Soil from station 6, North Massif, contains magnesian troctolitic anorthosite, which is a component that is rare in station-2 South-Massif soils. (4) Compositional differences between poikilitic impact-melt breccias from the two massifs suggest broad-scale heterogeneity in impact-melt breccia interpreted by most investigators to be ejecta from the Serenitatis basin.

We have found rock types not previously recognized or uncommon at the Apollo 17 site. These include (1) ITE-rich impact-melt breccias that are compositionally distinct from previously recognized "aphanitic" and "poikilitic" groups at Apollo 17; (2) regolith breccias that are free of mare components and poor in impact melt of the types associated with the main melt-breccia groups, and that, if those groups derive from the Serenitatis impact, may represent the pre-Serenitatis surface; (3) several VLT basalts, including an unusual very-high-K basaltic breccia; (4) orange-glass regolith breccias; (5) aphanitic-matrix melt breccias at station 6; (6) fragments of alkali-rich composition, including alkali anorthosite, and monzogabbro; (7) one fragment of 72275-type KREEP basalt from station 3; (8) seven lithic fragments of ferroan-anorthositic-suite rocks; and (9) a fragment of metal, possibly from an L chondrite. Some of these lithologies have been found only as lithic fragments in the soils and not among the large rock samples. In contrast, we have not found among the $2 \mathrm{~mm}-4 \mathrm{~mm}$ lithic fragments individual samples of certain lithologies that have been recognized as clasts in breccias (e.g., dunite and spinel troctolite).

The diversity of lithologic information contained in the lithic fragments of these soils nearly equals that found among large rock samples, and most information bearing on petrographic relationships is maintained, even in such small samples. Given a small number of large samples for "petrologic ground truth," small lithic fragments contained in soil "scoop" samples can provide the basis for interpreting the diversity of rock types and their proportions in remotely sensed geologic units. They should be considered essential targets for future automated sample-analysis and sample-return missions. 
,

湆

覆 彗 . 


\section{INTRODUCTION AND BACKGROUND}

What would we know about the rock types and geology of the surface of the Moon if the only samples we had were of the soils and small lithic fragments contained therein? As a precursor to future automated sampling or reconnaissance missions, we must determine how best to sample an area and what can be learned from different kinds of samples. Because of the diversity of rock types present and the complex geology of the site, the Apollo 17 landing site is ideal for comparing different kinds of sampling, such as remote sensing, direct chemical analysis of soils, and petrographic observations and chemical analysis of rocks of hand-sample size. In this paper, we (1) present compositional and petrographic information obtained on a large number of $2 \mathrm{~mm}-4 \mathrm{~mm}$ lithic fragments in soils collected from North- and South-Massif sampling stations, (2) determine the proportions of rock types represented in each soil, (3) compare the lithologic diversity and distribution between soils from the two massifs, and (4) compare the lithologic diversity of the $2 \mathrm{~mm}-4 \mathrm{~mm}$ fragments to that determined from large-rock samples, soil fines $(<1 \mathrm{~mm})$, and remotely-sensed data.

The Apollo 17 site is on the southeastern rim of the Serenitatis basin at the join of a bay of basaltic mare and tall massifs of highland material that form the Taurus-Littrow Valley (Fig. 1). From careful sampling by the Apollo 17 astronauts along traverses totaling $31 \mathrm{~km}$ and return of $120 \mathrm{~kg}$ of rock and soil, the major rock types present in the area are known. The floor of the TaurusLittrow Valley is underlain by high-Ti mare basalt and covered by a thick $(10 \mathrm{~m}-15 \mathrm{~m})$ regolith that is intermixed with pyroclastic orange and black glass. High-Ti mare basalts dominate the regolith from the valley floor, but the regolith also contains a significant amount of highland material (e.g., $8 \%-35 \%$ of the $<1 \mathrm{~mm}$ soil; Korotev and Kremser, 1992).

The Taurus-Littrow Valley is bordered by highland massifs consisting of incompatible-trace-element-(ITE)-bearing, noritic impact-melt breccias; ITE-poor feldspathic granulitic breccias; and some igneous rocks (Fig. 2). Many samples of impact-melt breccia were obtained from boulders near the base of the massifs. Most previously analyzed melt breccias fall into two compositionally

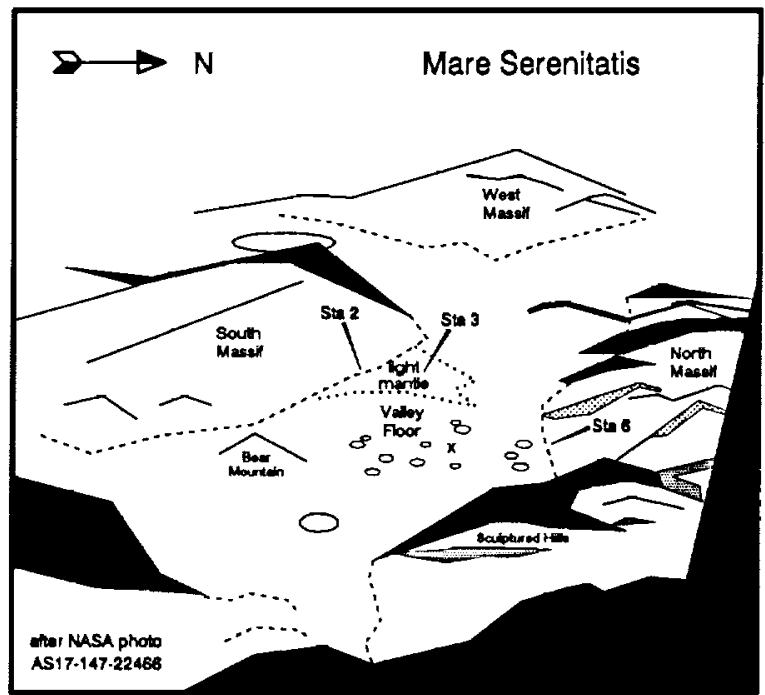

FIG. 1. Oblique view of the Apollo 17 landing site looking west (after NASA photo AS17-147-22466). Station 2 is at the base of South Massif, station 3 is on the "light mantle," and station 6 is on the lower slope of North Massif. The " $x$ " marks the location of the LM.

similar groups: the more abundant poikilitic-matrix breccias, presumably formed by the Serenitatis impact (Dymek ef al., 1976; Cadogan and Turner, 1976; Winzer et al., 1977; Spudis and Ryder, 1981), and the aphanitic-matrix breccias, which are thought by some to be Serenitatis melt breccia (Wolfe et al., 1981; James et al., 1978; Spudis, 1992) and by others to be unrelated to the Serenitatis event (Spudis and Ryder, 1981; Ryder, 1992b). In this paper, we presume that the Serenitatis impact formed the poikilitic-melt breccias of the massive boulder type; however, a Serenitatis origin for these breccias has not been proven.

Other lithologies are generally less coherent than the impactmelt breccias and are mainly represented by small rocks and lithic fragments in the soils, although they also occur as clasts in the melt breccias. They are dominated by feldspathic granulitic breccias but

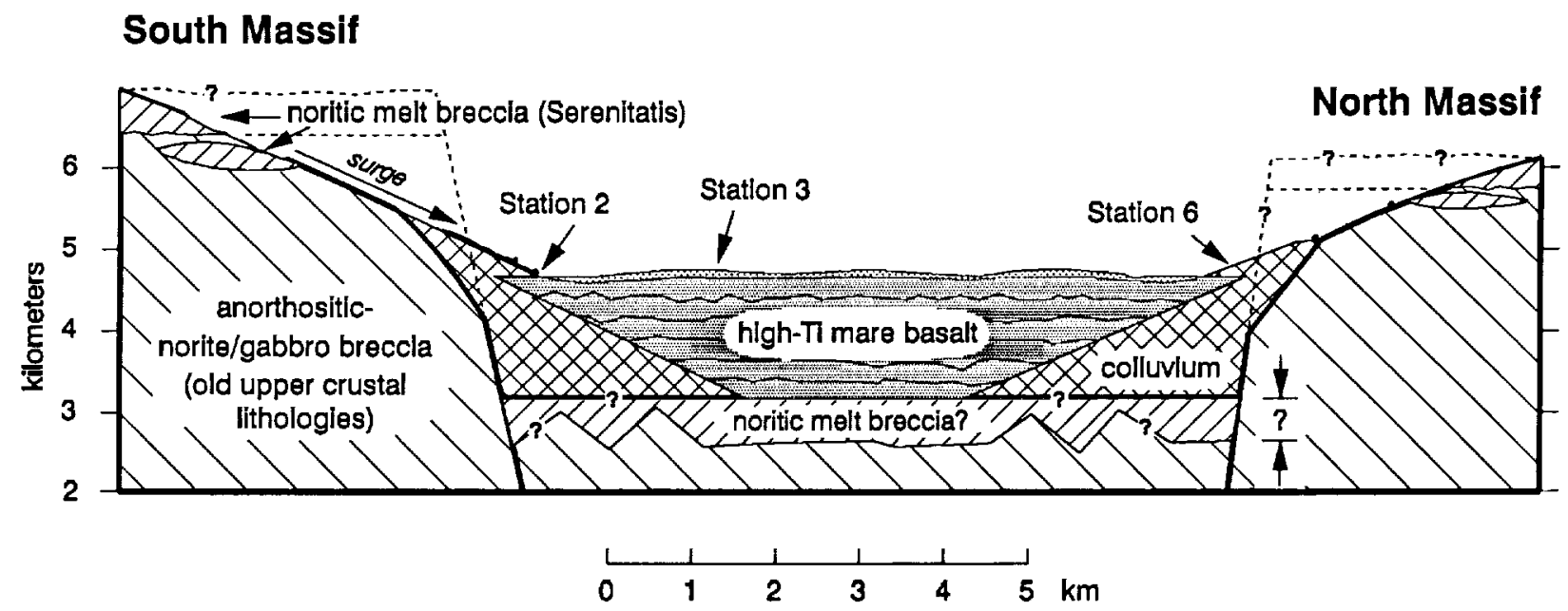

Fig. 2. Interpretive cross section of Taurus-Littrow Valley after Fig. 242 of Wolfe et al. (1981). Dashed lines denoting possible fault surfaces and preexisting massif "wedges" that now constitute colluvium in the valley represent just one possible interpretation of the origin of the massif slopes (Wolfe et $a l$, 1981). The arrow labeled "surge" represents the formation of the light mantle deposit from a secondary impact from Tycho at the top of South Massif (Luchitta, 1992). 
also include noritc, troctolite, dunite, and anorthositic gabbro of igneous origin. Ferroan anorthosite, such as that which is prevalent at the Apollo 16 site, is extremely rare (LSPET, 1973; Wolfe et al, 1981; James, 1992). A "light-mantle" surge deposit caused by a secondary impact from Tycho near the top of South Massif now lies at the base of the massif slope (Arvidson et al., 1976; Luchitta, 1992). Tycho secondaries are also responsible for the cluster of large craters that dot the valley floor (Luchitta, 1977). Soil samples vary in composition about the site, and this diversity can be related to the site geology and subsurface distribution of the major rock types (Rhodes et al., 1974; Korotev and Kremser, 1992).

The most intensely studied samples from Apollo 17 have been the rocks $(>1 \mathrm{~cm})$ and the "fine fines" ( $<1 \mathrm{~mm}$ sieved soils). For several reasons, we focus in this work on a relatively neglected subset of the samples, the $2 \mathrm{~mm}-4 \mathrm{~mm}$ grain-size fraction of the regolith. (1) There is a statistically significant number of $2 \mathrm{~mm}-4$ $\mathrm{mm}$ particles in most returned regolith samples. Typically $2 \%-3 \%$ of the mass of $<1 \mathrm{~cm}$ material is in the $2 \mathrm{~mm}-4 \mathrm{~mm}$ size range, and a $5 \mathrm{~g}$ sample of $2 \mathrm{~mm}-4 \mathrm{~mm}$ particles contains -200 fragments, compared to $\sim 30$ in a $5 \mathrm{~g}$ sample of $4 \mathrm{~mm}-10 \mathrm{~mm}$ particles. (2) Mass-balance models for $<1 \mathrm{~mm}$ soil indicate a different distribution of constituent rock types in the soil than is found among the returned large rocks (Korotev and Kremser, 1992). Thus, we might expect the distribution of lithologies in several hundred 2 $\mathrm{mm}-4 \mathrm{~mm}$ particles to be more representative of the site or a sampling station than the relatively small number of returned rocks. (3) As we show below, the $2 \mathrm{~mm}-4 \mathrm{~mm}$ particles are generally large enough to provide polymineralic assemblages that are representative, compositionally and petrographically, of the rocks from which they derive. In contrast, the $1 \mathrm{~mm}-2 \mathrm{~mm}$ grain-size fraction contains a larger proportion of individual mineral fragments (Blanchard et al, 1975; Ryder et al, 1988). (4) Unusual and interesting lithologies can be expected among the $2 \mathrm{~mm}-4 \mathrm{~mm}$ particles because of the large number of such particles and because vertical and lateral mixing from meteorite impacts has introduced some exotic material.

The amount of data obtained for the project described here is large (e.g., concentrations of 28 elcments in more than 800 samples, major element data for 93 samples, and petrographic observations, in thin section, of 95 samples). This report provides an overview of the study and concentrates on differences in distribution and compositions of lithologies between the two massifs and the relationship of the $2 \mathrm{~mm}-4 \mathrm{~mm}$ grain-size fraction to the $<1 \mathrm{~mm}$ fines. We have also obtained much new information about specific rock types (Jolliff and Bishop, 1993; Rockow et al, 1994a,b; Korotev et al., 1995a; Jolliff et al., 1995); details of results for particular subsets of the samples will appear in subsequent papers.

\section{DATA SOURCES AND COLLECTION}

\section{Soil Samples and Genealogy}

Most of the regolith samples that were collected with scoops (as opposed to coring equipment) during the Apollo 17 mission were passed through sicves with mesh sizes of $1,2,4$, and $10 \mathrm{~mm}$. Collectively, the subcentimeter material has been regarded as "fines" or "soil" and designated 7Sxx0, where $S$ usually designates the station number and the terminal zero indicates unsieved fines. Most regolith studies have been based on the $<1 \mathrm{~mm}$ fines ("fine fines"), designated $7 \mathrm{~S} \times x \times 1$. The $2 \mathrm{~mm}-4 \mathrm{~mm}$ fractions are designated $7 \mathrm{~S} \times 3$ 3. We have analyzed a total of 789 lithic fragments by instrumental neutron activation analysis (INAA) from the following samples: $72443,72503,73243,76283$, and 76503. We assigned each particle analyzed by INAA a sequential designation ",7xxx" beginning with ,7001, and we associate this number with any corresponding chips in thin sections and fused beads.

We received a $5 \mathrm{~g}$ split for each sample except $72443(2 \mathrm{~g})$. The allocated splits were an unbiased subset of all material in the respective grain-size fractions, and we have analyzed all the allocated material from 72443, 72503, and 76503. We have reserved -10 particles from 76283 and $\sim 30$ particles from 73243 , all of which appear to be melt breccias, for future analysis.

Samples 76283 and 76503 were collected at station 6 (Fig. 3a), which is located $250 \mathrm{~m}$ upslope from the base of the North Massif. The most prominent feature at station 6 is a cluster of five meltbreccia blocks ( $3 \mathrm{~m}-10 \mathrm{~m}$ in size) that lic at the end of a single boulder track. Sample 76283 is from the $2 \mathrm{~cm}-5 \mathrm{~cm}$ depth interval in the regolith just north and beyond the overhang of boulder block 4. Sample 76503 was collected $-25 \mathrm{~m}$ to the west of the boulder cluster and is from the upper few centimeters of regolith in the cjecta blanket of a small crater (Wolfe et al., 1981). We selected sample 76503 as one that would be representative of the regolith on the Iower part of North-Massif slopes, unaffected by comminution or shedding of material off the boulder blocks. Sample 76283 was selected as one that might potentially show the effects of material added to the local soil by breakup of the boulder. Corresponding $<1 \mathrm{~mm}$ soil samples 76281 and 76501 are submature with $\mathrm{I}_{\mathrm{S}} / \mathrm{FeO}=$ 45 and 58, respectively (Morris et al, 1983). Both of these samples $(76280,76500)$ contain admixed mare-basalt and orange/black-glass debris from the valley floor (Heiken and McKay, 1974; Wolfe et al., 1981).

Samples 72443 and 72503 were collected at station 2 (Fig. 3b), which is at the base of the South Massif on the rim of the $I \mathrm{~km}$ diameter Nansen Crater. Most station-2 samples were taken from or near three small boulders. Sample 72443 is from the upper $4 \mathrm{~cm}$ of soil under boulder 3, collected after the astronauts overturned the boulder (Wolfe et al., 1981). Sample 72503 is from the upper $4 \mathrm{~cm}$ of regolith $\sim 5 \mathrm{~m}$ from boulder 2 . We expected sample 72503 to represent the local soil that was least affected by addition of boulder material and sample 72443 to be potentially enriched in boulder material. Corresponding $<\mathrm{I} \mathrm{mm}$ fines, 72441 and $7250 \mathrm{l}$, are mature, $\mathrm{I}_{\mathrm{S}} / \mathrm{FeO}=68$ and 81 , respectively (Morris et al., 1983)

Station 3 (Fig. 3c) is at the base of the Lee-Lincoln scarp and 50 $\mathrm{m}$ east of Lara crater. Sample 73243 is from the upper $5 \mathrm{~cm}$ of a trench sequence taken on the rim of a $10 \mathrm{~m}$ crater (Wolfe et al., 1981). The corresponding $<\mathrm{I} \mathrm{mm}$ fines, 73241 , are immature, $I_{S} / \mathrm{FeO}=18$ (Morris, et al., 1983). Both stations 2 and 3 are on top of the light mantle, which is a tongue of highland material extending from the base of South Massif midway across the valley floor. Although station 3 is several kilometers from the base of South Massif, it lies on South-Massif material (light mantle); thus, we refer to station-2 and station-3 samples collectively as South-Massif material.

\section{Analytical Techniques}

Instrumental Neutron Activation Analysis (INAA)-Fach $2 \mathrm{~mm}-$ $4 \mathrm{~mm}$ lithic fragment was bathed ultrasonically in acetone, then examined and tentatively classified under a binocular microscope prior to weighing and sealing in ultra-pure silica tubing for neutron irradiation. To provide an unbiased accounting of the mass balance, all fine $(<2 \mathrm{~mm})$ material produced during shipping, washing, and handling of the particles was also analyzed; these "abrasion fines" amounted to $4 \%-8 \%$ of the allocated sample mass. Two or more samples of the corresponding $<1 \mathrm{~mm}$ fines samples (7SxxI) were also analyzed for cach soil. The lunar particles and 

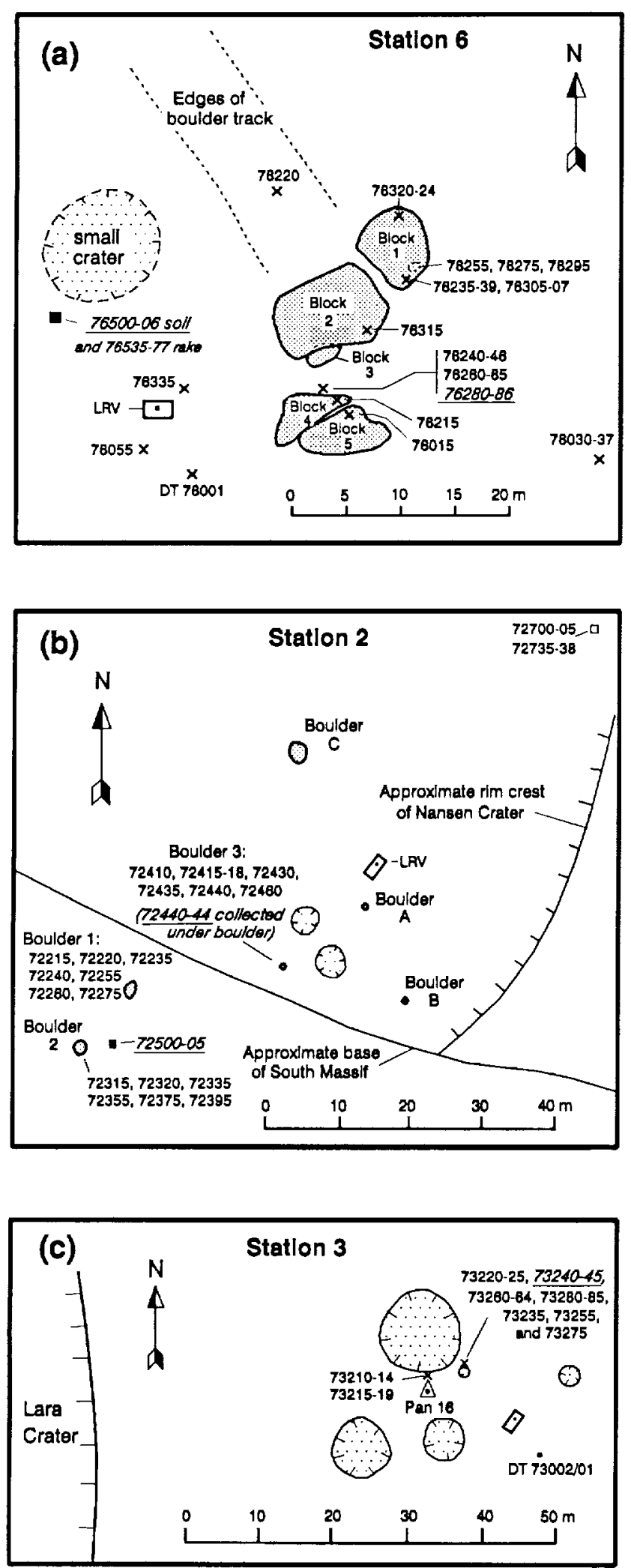

FIG. 3. Planimetric maps of (a) station 6, (b) station 2, and (c) station 3 after figures 146,72, and 98, respectively, of Wolfe et al. (1981). Samples analyzed in this work are in italics and underlined, these include 76283 , $76503,72443,72503$, and 73243 . fragments of synthetic glass standards were irradiated in batches of $\sim 100$ particles for $24 \mathrm{~h}$ with a thermal neutron flux of $\sim 5 \times 10^{13} \mathrm{~cm}^{-2} \mathrm{~s}^{-1}$. Wc radioassayed samples and standards three times: at 6 days, $7-11$ days, and 26-3I days after irradiation. The INAA methods are described by Korotev (1991).

Fused Beads, Thin Sections, and Electron Microprobe Analysis (EMPA)-After INAA, 88 particles from 72503 and 76503 were selected for major-element analysis by EMPA-FB (electron microprobe analysis of fused beads) by the method of Brown (1977). Individual lithic fragments typically weighing $10 \mathrm{mg}-20 \mathrm{mg}$ were first ground with an alumina mortar and pestle under acetone. Powders were then fused on a Mo-strip rcsistance heater under $\mathrm{Ar}$ at atmospheric pressure. Fifty-one of the samples from 72503 and 76503 selected for fused bead analysis were first split for thin sections. Our procedure is as follows: the entire fragment is encased in water-soluble Crystal Bondrm and sawn in half using a diamond wafer blade. The Crystal Bondrm is dissolved in hot distilled water and the rock chips rinsed in acetone. Half of each fragment is made into a polished thin section and the other half is used to prepare a fused bead. Wavelengthdispersive EMP analyses of fused beads are done at $15 \mathrm{kV}$ accelerating voltage and $\sim 30 \mathrm{nA}$ beam current with a broad beam $(30 \mu \mathrm{m}-50 \mu \mathrm{m})$ using the JEOL 733 at Washington University, St. Louis. A minimum of 6 spot analyses are done on each bead. Concentrations of $\mathrm{FeO}, \mathrm{CaO}, \mathrm{Cr}_{2} \mathrm{O}_{3}$, and $\mathrm{Na}_{2} \mathrm{O}$ determined by INAA and by EMPA-FB on the same samples compare well (usually within $\sim 3 \%$, relative, for $\mathrm{CaO}, 5 \%$ for $\mathrm{FeO}$ and $\mathrm{Na}_{2} \mathrm{O}$, and $10 \%$ for $\mathrm{Cr}_{2} \mathrm{O}_{3}$ ). Concentrations of $\mathrm{Na}_{2} \mathrm{O}$ determined by EMPA-FB are systematically low by $\sim 5 \%$, presumably due to volatilization during fusion. Concentrations of FeO determined by EMPA-FB are systematically low by $\sim 4 \%$; however, if we estimate the portion of $\mathrm{Fe}$ present as metal based on $\mathrm{Ni}$ concentrations, subtract it from FeO by INAA, and then compare the two values, FeO by EMPA-FB is within $2 \%$ of values by INAA (see also Korotev, 1990). We attribute this to preferential loss of $\mathrm{Fe}^{n}$ by reaction with Mo during fusion of the sample powder.

\section{RESULTS}

The $2 \mathrm{~mm}-4 \mathrm{~mm}$ particles found in the regolith at the South and North Massifs are highly varied in composition. For the most part, they correspond to lithologies known from the collection of large rocks. Despite their small mass, the $2 \mathrm{~mm}-4 \mathrm{~mm}$ fragments are generally large enough to be representative of a particular lithology. The assignment of lithologies and the distribution of compositions for the particles are shown on plots of Sc vs. Sm (Figs. 4a, 5a, and 6a). Both $\mathrm{Sc}$ and $\mathrm{Sm}$ are determined with high precision by our INAA procedures (relative standard deviation of $<2 \%$ ). The pyroxenes, particularly clinopyroxene, concentrate Sc, so the Sc concentration of a lithic fragment distinguishes plagioclase-rich highland lithologies from pyroxene-rich mare basalts. The Sm concentration, representative of ITE concentrations, distinguishes impact-melt breccias from ITE-poor highland lithologies and from mare-basalt fragments. The distribution of compositions is also shown in terms of major elements in plots of $\mathrm{CaO}$ s. $\mathrm{FeO}$ (Figs. $4 \mathrm{~b}$, $5 b, 6 b)$.

We base the assignment of rock type of individual lithic fragments on a combination of binocular-microscope observations, examination of petrographic thin sections of a subset of the fragments, and chemical compositions. Compositions of a representative subset of individual lithic fragments are given in tables in the appendix. Mass-weighted mean compositions for all of the $2 \mathrm{~mm}-4 \mathrm{~mm}$ particles in unbiased splits of samples from station 2 (72443, 72503) and station 6 (76503) are given in Table 1 and compositions for specific groups of samples are given in Tables 24. For comparison, compositions of previously characterized Apollo 17 samples from all sample stations, taken from the literature, are shown in Fig. 7. In the following sections, we summarize some of the specific characteristics that distinguish the rock types we have found among the $2 \mathrm{~mm}-4 \mathrm{~mm}$ lithic fragments, and we place them in the context of known Apollo 17 rock types by first giving a short summary of similar rock types reported in the literature. 

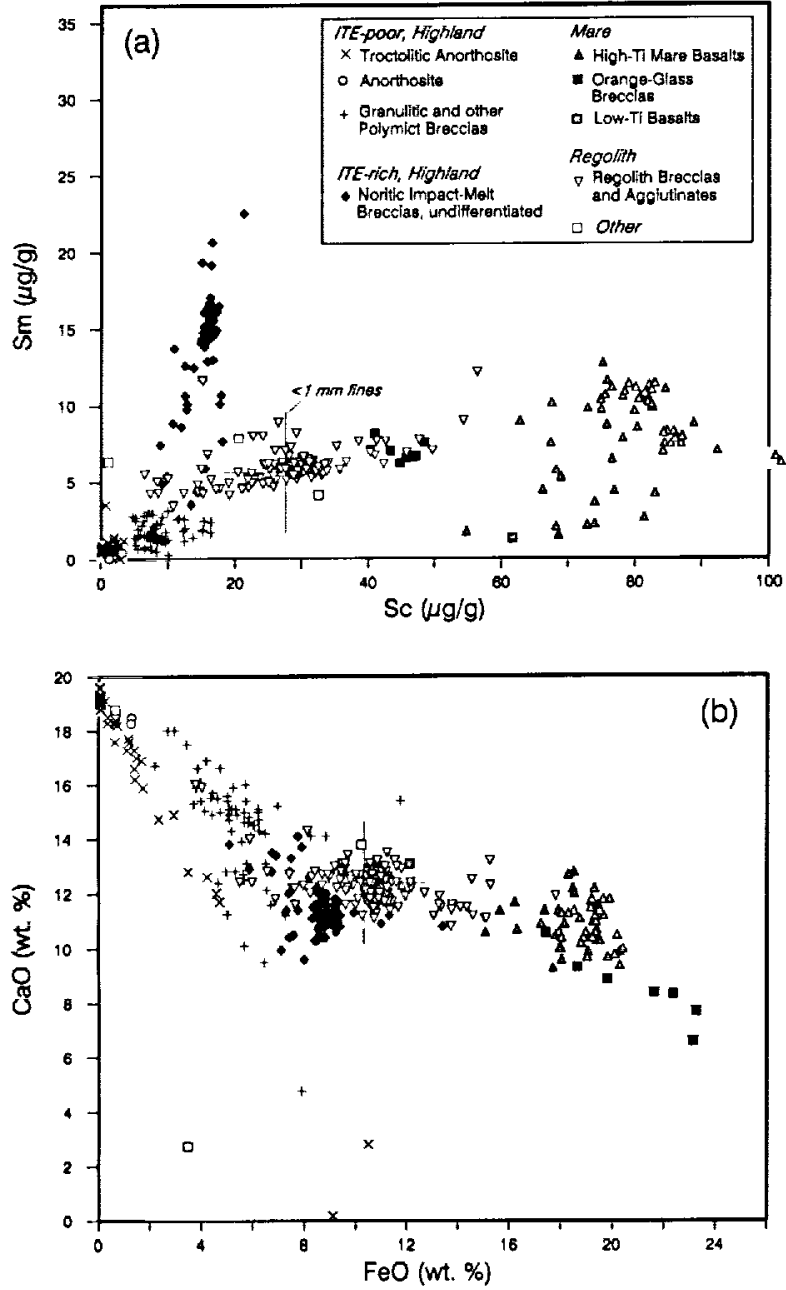

FIG. 4. Compositions of lithic fragments from samples 76503 and 76283 , station 6, North Massif. Data include 243 particles from 76503 and 149 particles from 76283. (a) Concentrations of $\mathrm{Sc} v s$. Sm. (b) $\mathrm{FeO} v s$. $\mathrm{CaO}$. "Others" include alkali anorthosite $(1.3 \mu \mathrm{g} / \mathrm{g} \mathrm{Sc}, 0.7 \mathrm{wt} \% \mathrm{FeO})$, felsite $(21$ $\mu \mathrm{g} / \mathrm{g} \mathrm{Sc}, 3.5 \% \mathrm{FcO})$, and gabbro-noritic breccia $(32.6 \mu \mathrm{g} / \mathrm{g} \mathrm{Sc}, 10.3 \% \mathrm{FeO})$ Thin lines labeled " $<1 \mathrm{~mm}$ fines" intersect at the composition of 76501 , the $<1 \mathrm{~mm}$ split corresponding to 76503 . Symbols explained in (a) apply also to (b).

\section{Regolith Breccias and Agglutinates}

Many of the particles in each sample are regolith breccias and agglutinates that have compositions vcry similar to the corresponding $<1 \mathrm{~mm}$ fines (Figs. 4-7). These are mostly dark, glassy-matrix, clast-rich breccias but also include breccias that were lithified by compaction. In thin section, these contain recognizable regolith components, such as spheres and broken fragments of glass, and a wide variety of lithic and mineral clasts. Compositionally, they are also distinguished by high $\mathrm{Zn}$ concentrations compared to particles consisting largely of crystalline material (e.g., Table 3). Because the $<1 \mathrm{~mm}$ fines from each Apollo 17 sampling station are compositionally distinct from those of other stations (Korotev and Kremser, 1992), the compositional similarity between the regolith breccias (Table 3 ) and the corresponding $<1 \mathrm{~mm}$ fines (Table 1) indicates that most of the regolith breccias and agglutinates were formed locally during induration of soil by impact of micro-
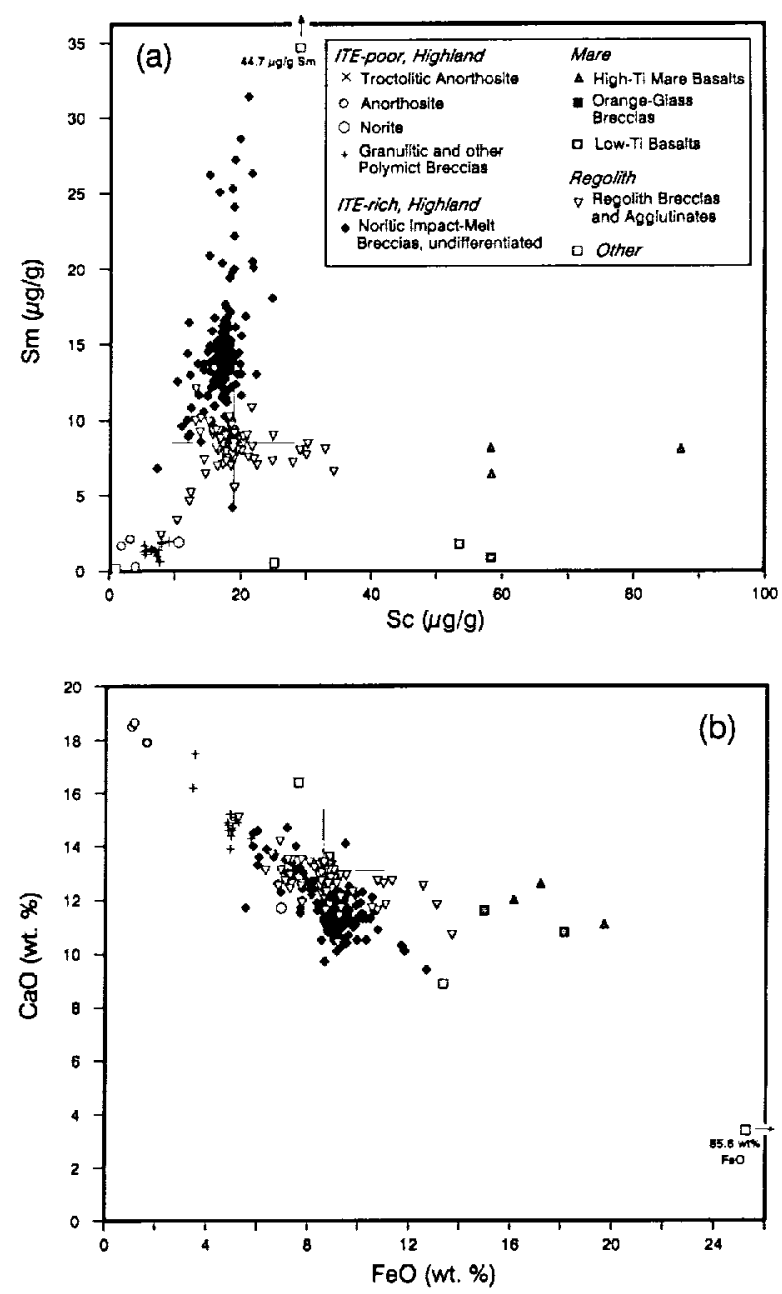

FIG. 5. Compositions of lithic fragments from samples 72443 and 72503 station 2, South Massif. Data include 207 particles from 72503 and 84 from 72443. (a) Concentrations of Sc vs. Sm; (b) FeO vs. CaO. "Others" include a metal-rich particle $(1 \mu \mathrm{g} / \mathrm{g} \mathrm{Sc}, 86 \mathrm{wt} \% \mathrm{FeO})$, gabbroic breccia $(25 \mu \mathrm{g} / \mathrm{g} \mathrm{Sc}$, $7.6 \% \mathrm{FeO}$ ), and monzogabbro breccia ( $29 \mu \mathrm{g} / \mathrm{g} \mathrm{Sc}, 13.3 \% \mathrm{FeO})$. Symbols explained in (a) apply to (b) and are the same as in Fig. 4. Thin intersecting lines mark the composition of $72501<1 \mathrm{~mm}$ fines.

meteorites (see also Simon et al., 1990; Blanchard et al., 1975). At station 6 , however, $25 \%-30 \%$ of the regolith-breccia particles are compositionally distinct from the main cluster (e.g., Fig. 4) and from the corresponding $<1 \mathrm{~mm}$ fines; these breccias may have been produced in a regolith of different composition than that presently existing at station 6. For example, those regolith-breccia particles with high Sc concentrations ( $>35 \mu \mathrm{g} / \mathrm{g}$, e.g., 76503,7027, Table A4) are similar in composition to soils to the east (stations 7,8 , and 9) and reflect a higher proportion of admixed basalt near the interface of the base of North Massif and the basaltic valley floor. Similarly, $\sim 15 \%$ of the regolith-breccia particles from the South Massif are sufficiently dissimilar to the soils of stations 2 and 3 that they were probably not formed in soil of this composition (e.g., Figs. 5, 6). Many have higher concentrations of $\mathrm{Sc}$ and were probably formed closer to the interface of the light mantle and the basaltic valley floor. 

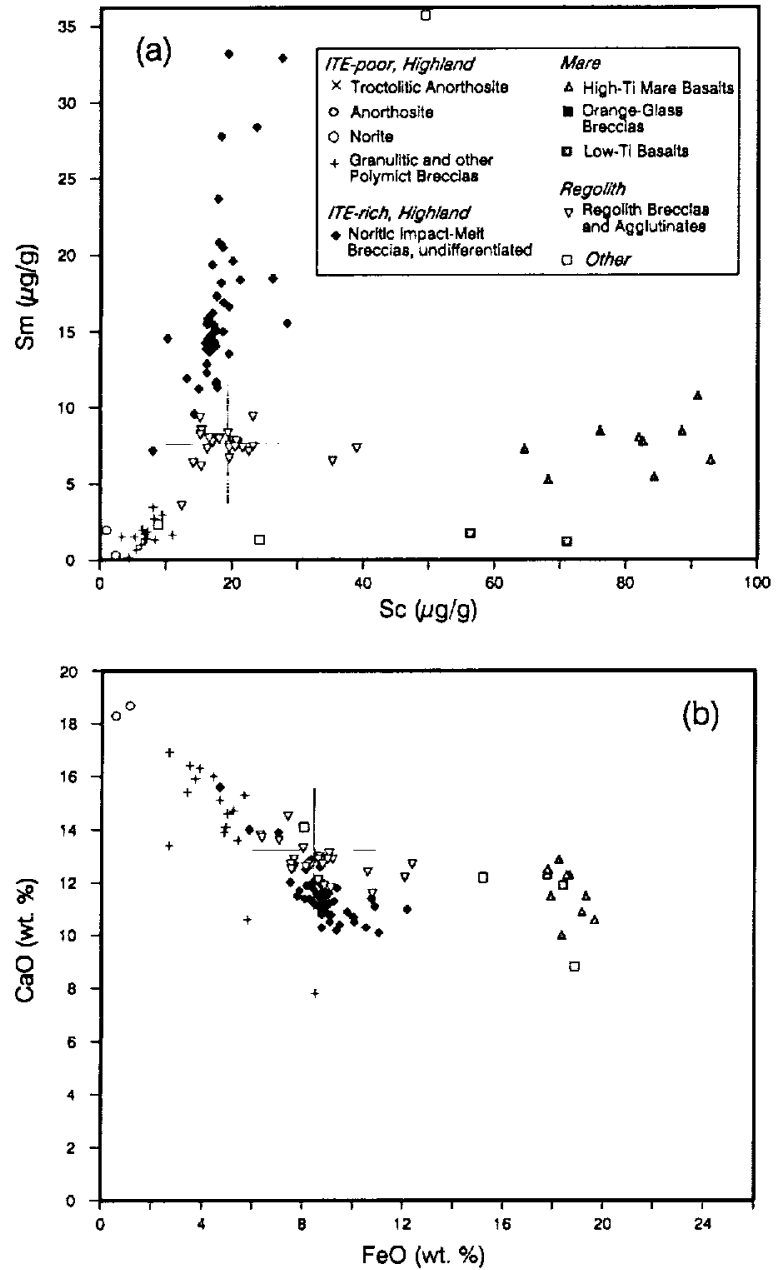

FIG. 6. Compositions of lithic fragments from sample 73243, station 3 , South Massif. Data include 106 particles from 73243. (a) Concentrations of $\mathrm{Sc}$ vs. Sm. (b) $\mathrm{FeO}$ vs. CaO. "Others" include a metal-rich particle $(9$ $\mu \mathrm{g} / \mathrm{g} \mathrm{Sc}, 18.9 \mathrm{wt} \% \mathrm{FeO})$, gabbroic breccia $(24 \mu \mathrm{g} / \mathrm{g} \mathrm{Sc}, 8 \% \mathrm{FeO})$, and KREEP basalt $(49 \mu \mathrm{g} / \mathrm{g} \mathrm{Sc}, 15.2 \% \mathrm{FeO})$. Symbols explained in (a) apply to (b) and are the same as in Fig. 4. Thin intersecting lines mark the composition of $73241<1 \mathrm{~mm}$ fines.

Because the regolith at station 6 contains subequal amounts of each of the major lithologies found at the site, including mare basalt and orange glass, station- 6 regolith breccias plot toward the center of the distribution of rock compositions on most two-element plots (Fig. 4a). In addition to regolith breccias that have compositions similar to the local soil and those that have more basaltic compositions, some regolith breccias at station 6 consist only of ITE-poor highland components (e.g., 76503,7047 and 76503,7129, Table 14). These breccias lack mare components (e.g., low Sc concentrations) and, thus, may predate the eruption of mare basalts on the valley floor. They are discussed in more detail in the following section.

\section{Incompatible-Trace-Element-poor Highland Rock Types}

Highland granulitic breccias and monomict igneous rock types occur in the Apollo 17 sample collection as small rocks, as clasts in melt breccias, and as fragments in the soils. Among the returned rocks, less than 10 of these types have masses exceeding $50 \mathrm{~g}$. The
TABLE I. Mass-weighted mean compositions of $2 \mathrm{~mm}-4 \mathrm{~mm}$ particles and corresponding $<1 \mathrm{~mm}$ soil.

\begin{tabular}{|c|c|c|c|c|c|c|}
\hline & $\begin{array}{l}72441 \\
<1 \mathrm{~mm}\end{array}$ & $\begin{array}{c}72443 \\
2-4 \mathrm{~mm}\end{array}$ & $\begin{array}{l}72501 \\
<1 \mathrm{~mm}\end{array}$ & $\begin{array}{c}72503 \\
2-4 \mathrm{~mm}\end{array}$ & $\begin{array}{l}76501 \\
<1 \mathrm{~mm}\end{array}$ & $\begin{array}{c}76503 \\
2-4 \mathrm{~mm}\end{array}$ \\
\hline $\mathrm{Na}_{2} \mathrm{O}$ & 0.47 & 0.57 & 0.45 & 0.55 & 0.38 & 0.45 \\
\hline $\mathrm{CaO}$ & 13.0 & 12.0 & 13.1 & 12.3 & 12.4 & 12.8 \\
\hline $\mathrm{Sc}$ & 19.6 & 20.0 & 18.9 & 16.7 & 27.6 & 24.5 \\
\hline $\mathrm{Cr}$ & 1568 & I553 & 1495 & 1396 & 1814 & 1553 \\
\hline $\mathrm{FeO}$ & 8.99 & 9.32 & 8.52 & 8.36 & 10.30 & 9.01 \\
\hline $\mathrm{Co}$ & 30.5 & 32.4 & 27.6 & 30.0 & 33.1 & 26.4 \\
\hline $\mathrm{Ni}^{1}$ & 267 & 283 & 250 & $262-270$ & 206 & 176 \\
\hline $\mathrm{Zn}^{1}$ & 31 & 24 & 26 & 18 & 40 & $24-35$ \\
\hline $\mathrm{Rb}$ & 4 & 7 & 6 & 7 & 6 & 5 \\
\hline $\mathrm{Sr}$ & 150 & 160 & 143 & 159 & 127 & 160 \\
\hline $\mathrm{Zr}^{1}$ & 248 & 359 & 248 & 370 & 152 & $190-202$ \\
\hline $\mathrm{Cs}^{1}$ & 0.18 & 0.22 & 0.16 & 0.22 & 0.12 & $0.17-0.18$ \\
\hline $\mathbf{B a}$ & 209 & 271 & 209 & 283 & 122 & {$[40$} \\
\hline $\mathrm{La}$ & 18.5 & 25.1 & 17.3 & 26.0 & 9.00 & 11.5 \\
\hline $\mathrm{Ce}$ & 48.2 & 64.7 & 45.4 & 67.1 & 24.8 & 30.6 \\
\hline $\mathrm{Nd}$ & 28.4 & 38.0 & 26.5 & 39.0 & 15.7 & 19.0 \\
\hline $\mathrm{Sm}$ & 8.89 & 11.71 & 8.45 & 11.9 & 5.63 & 6.43 \\
\hline $\mathrm{Eu}$ & 1.36 & 1.57 & 1.32 & I.59 & 1.26 & 1.37 \\
\hline $\mathrm{Tb}$ & 1.85 & 2.36 & 1.76 & 2.40 & 1.25 & 1.40 \\
\hline $\mathrm{Yb}$ & 6.52 & 8.51 & 6.16 & 8.57 & 4.54 & 5.16 \\
\hline Lu & 0.91 & 1.15 & 0.86 & 1.17 & 0.64 & 0.71 \\
\hline $\mathrm{Hf}$ & 7.0 & 9.0 & 6.5 & 9.4 & 4.6 & 5.3 \\
\hline Ta & 0.90 & 1.17 & 0.86 & 1.20 & 0.69 & 0.79 \\
\hline $\mathbf{l r}^{1}$ & 8.6 & $7.8-8.2$ & 7.9 & $7.6-8.1$ & 6.8 & $6.2-7.5$ \\
\hline$A u^{\prime}$ & 5.5 & $4.1-4.4$ & 3.8 & $3.9-4.2$ & 2.9 & $2.4-4.9$ \\
\hline Th & 3.0 & 3.9 & 3.0 & 4.2 & 1.44 & 1.94 \\
\hline $\mathrm{U}$ & 0.82 & 1.08 & 0.82 & 1.2 & 0.39 & $0.57-0.64$ \\
\hline \multicolumn{7}{|c|}{ mass (mg) } \\
\hline & 175 & 1985 & 305 & 4888 & 307 & 4941 \\
\hline
\end{tabular}

Concentrations of $\mathrm{Na}_{2} \mathrm{O}, \mathrm{CaO}$, and $\mathrm{FeO}$ in wt\%, $\mathrm{Au}$ and Ir are in $\mathrm{ng} / \mathrm{g}$, and all others in $\mu \mathrm{g} / \mathrm{g}$. Mass-weighted mean composition of $2 \mathrm{~mm}-4 \mathrm{~mm}$ lithic fragments from sample 72503 excludes the composition of metal-rich particle 72503,7052 (see Table 5).

'Where a range is given, some of the individual samples had concentrations below our detection limits. For the range given, the lower average concentration value was calculated using a concentration of zero for those samples in which concentrations were below detection, making this a lower limit. The higher value was calculated using the mean composition of only those samples for which a concentration value was obtained, yielding an upper limit.

majority of the igneous rocks belong to the magnesian suite; only a few small samples have ferroan or alkaline mineral compositions (e.g., Warren et al., 1991), although some of the well-studied lunar granites were found as clasts in boulders of station 2 (Ryder et al, 1975b) and station 3 (James and Hammarstrom, 1977). Of the magnesian-suite igneous rock types, troctolites and norites are most abundant and are about equally represented. Granulitic breccias are also abundant. They have compositions ranging from noritic/ gabbroic anorthosite to anorthositic gabbro and, based on values of whole-rock $\mathrm{Mg}$ ' [molar $\mathrm{MgO} /(\mathrm{MgO}+\mathrm{FeO})]$, have been divided into a magnesian group and a less abundant ferroan group (Lindstrom and Lindstrom, 1986).

Among the $2 \mathrm{~mm}-4 \mathrm{~mm}$ fragments, we find granulitic breccias in samples from both massifs, although they are relatively more abundant in the North-Massif samples (Figs. 4a, 5a). Most appear as nonvesicular, light-colored, recrystallized breccias under the binocular microscope. In thin section, their textures range from fine- to medium-grained, and are partially recrystallized, with 
TABLE 2. Mass-weighted mean compositions of lithologic groups (intergroup comparison')

\begin{tabular}{|c|c|c|c|c|c|c|c|c|c|c|c|c|c|c|}
\hline & \multicolumn{4}{|c|}{ ITE-poor Highlands } & \multicolumn{3}{|c|}{ Impact Melt Breccia } & \multirow[b]{2}{*}{$\begin{array}{c}\text { Basalt } \\
\text { (A) }\end{array}$} & \multirow[b]{2}{*}{$\begin{array}{c}\text { Basalt } \\
\text { (B1) }\end{array}$} & \multirow[b]{2}{*}{$\begin{array}{c}\text { Basalt } \\
\text { (B2) }\end{array}$} & \multirow{2}{*}{$\begin{array}{c}\text { Mare } \\
\text { Basalt } \\
\text { (C) }\end{array}$} & \multirow[b]{2}{*}{$\begin{array}{l}\text { Other }^{3} \\
\text { Basalt }\end{array}$} & \multirow[b]{2}{*}{$\begin{array}{c}\text { VLT } \\
\text { Basalt }\end{array}$} & \multirow[b]{2}{*}{$\begin{array}{l}\text { Orange } \\
\text { GI Bx }\end{array}$} \\
\hline & $\begin{array}{l}\text { Mag } \\
\text { Gran }\end{array}$ & $\begin{array}{c}\text { Ferroan } \\
\text { Gran }\end{array}$ & $\begin{array}{l}\text { Troct } \\
\text { Anorth }\end{array}$ & $\begin{array}{l}\text { Ferroan } \\
\text { Anorth }\end{array}$ & $\begin{array}{c}\text { Poik } \\
\text { Matrix }^{2}\end{array}$ & $\begin{array}{l}\text { Aphan } \\
\text { Matrix }\end{array}$ & $\begin{array}{l}\text { ITE- } \\
\mathrm{x} \text { rich }\end{array}$ & & & & & & & \\
\hline $\mathrm{CaO}$ & 15.0 & 15.0 & 16.2 & 18.4 & 11.5 & 12.5 & 11.4 & 11.1 & 10.9 & 11.3 & 10.8 & 11.2 & 11.8 & 8.0 \\
\hline Sc & 7.5 & 12.4 & 1.0 & 2.2 & 16.9 & 16.7 & 19.7 & 80.0 & 81.9 & 86.9 & 82.8 & 68.5 & 62.5 & 46.5 \\
\hline $\mathrm{Cr}$ & 784 & 884 & 322 & 125 & 1342 & 1463 & 1397 & 2847 & 3736 & 2541 & 4317 & 3556 & 3121 & 4468 \\
\hline $\mathrm{Ni}$ & 449 & 362 & 23 & $12-15$ & 298 & 207 & 190 & I5-34 & $15-24$ & 19-38 & 20 & 43 & $34-99$ & $131^{5}$ \\
\hline $\mathrm{Zn}$ & $7-8$ & $\mathrm{I}-3$ & 2 & 2 & 17 & 17 & 22 & -- & --- & $\cdots$ & -..- & $\ldots$ & $\cdots$ & 222 \\
\hline $\mathrm{Rb}$ & 3 & 2 & 1 & 1 & 7 & 8 & 14 & 7 & 5 & 5 & 6 & 4 & $7^{4}$ & 6 \\
\hline $\mathrm{Sr}$ & 151 & 145 & 163 & 179 & 169 & 146 & 160 & 184 & 145 & 140 & 135 & 110 & 37 & 210 \\
\hline $\mathrm{Zr}$ & 45 & 40 & 6 & $36-40$ & 465 & 414 & 725 & 282 & 184 & 216 & 169 & 112 & 32 & 190 \\
\hline $\mathrm{Cs}$ & 0.10 & 0.06 & 0.05 & $0.01-0.02$ & 0.22 & 0.27 & 0.61 & $0.10-0.14$ & $0.10-0.11$ & $0.04-0.11$ & 0.06 & $0.08-0.11$ & $0.04-0.1^{4}$ & $0.10-0.20$ \\
\hline $\mathrm{Ba}$ & 59 & 43 & 48 & 30 & 340 & 319 & 504 & 81 & 69 & 74 & 63 & 75 & $28^{4}$ & 84 \\
\hline Eu & 0.84 & 0.79 & 1.08 & 0.96 & I. .89 & 1.4 & 1.92 & 2.19 & 1.81 & 1.58 & 1.61 & 1.09 & 0.39 & 1.78 \\
\hline $\mathrm{Tb}$ & 0.33 & 0.34 & 0.12 & 0.22 & 2.95 & 2.74 & 4.65 & 2.82 & 2.12 & 2.04 & 2.19 & 1.43 & 0.35 & $\mathrm{I} .50$ \\
\hline $\mathrm{Yb}$ & 1.54 & I. 45 & 0.35 & 0.73 & I0.4 & 9.74 & 16.3 & 10.4 & 7.97 & 7.8 & 7.96 & 5.33 & 1.98 & 4.49 \\
\hline Lu & 0.22 & 0.20 & 0.04 & 0.10 & 1.42 & 1.32 & 2.20 & 1.44 & 1.12 & 1.09 & 1.12 & 0.75 & 0.29 & $0.6 \mathrm{I}$ \\
\hline Hf & 1.2 & 1.0 & 0.2 & 0.9 & I1.6 & 10.3 & 17.7 & 9.8 & 8.0 & 7.2 & 7.9 & 4.7 & 1.0 & 5.9 \\
\hline $\mathrm{Ta}$ & $0.2 \mathrm{I}$ & 0.12 & 0.02 & $0.08-0.1$ & 1.49 & 1.24 & 2.09 & 1.85 & 1.53 & 1.58 & 1.51 & 0.74 & 0.09 & 1.03 \\
\hline Ir & 21.0 & 14.1 & $0.1-0.2$ & $0.3-0.4$ & $7.7-8.1$ & 5.5 & $4.2-4.4$ & $1.1-2.3$ & $1.2-2.0$ & $1.5-2.8$ & 1.5 & $1.7-2.4$ & $0.26-1.0$ & $2.5-5^{5}$ \\
\hline $\mathrm{Au}$ & $6.9-8$ & 5.3 & $0.2-0.5$ & 0.2 & $4.8-5.0$ & 3.5 & $2.9-3.2$ & $1.1-2.3$ & $0.1-1.0$ & $0.2-0.8$ & $0.7-3.0$ & $0.8-3.0$ & $0.1-1.6$ & $1.5^{5}$ \\
\hline Th & 0.90 & 0.64 & 0.11 & 0.37 & 5.07 & 5.06 & 8.64 & 0.29 & 0.18 & 0.32 & 0.18 & 0.32 & 0.23 & 0.64 \\
\hline $\mathrm{U}$ & 0.27 & 0.2 & 0.03 & 0.08 & 1.39 & 1.39 & 2.35 & $0.14-0.20$ & $0.18-0.21$ & $0.21-0.35$ & 0.15 & $0.06-0.08$ & $0.12-0.14$ & 0.23 \\
\hline$\#$ & 48 & 7 & 35 & 7 & 189 & 32 & 31 & 24 & 7 & 15 & 2 & 3 & 5 & 4 \\
\hline mass & 1390 & 130 & 713 & 252 & 4510 & 751 & 649 & 740 & 260 & 381 & 126 & 88 & 138 & 136 \\
\hline
\end{tabular}

1 Compositions are averages for lithic fragments from samples $7650 \overline{3}, \overline{7} 62 \overline{8} \overline{3}, 7 \overline{2} 50 \overline{3}, 72443,73243$. In general, the groups listed have a very limited compositional range (i.e., each group represents a distinct lithology). Exceptions include the aphanitic and ITE-rich melt breccia groups, which have distinctive but diverse compositions, and troctolitic anorthosite, which is a group of related mineral fragments and breccias that form a compositional trend rather than a cluster. Most groups are also well characterized (i.e., many particles per group and lithology can be assigned with confidence based solely on IN $\Lambda$ data). Exceptions include the ferroan anorthosite particles and some of the basalt particles, which require detailed petrographic work to confirm specific lithologic assignment. Concentrations of $\mathrm{Na}_{2} \mathrm{O}, \mathrm{CaO}$, and $\mathrm{FeO}$ are in $\mathrm{w} \%$, Ir and $\mathrm{Au}$ are in $\mathrm{ng} / \mathrm{g}$, and the remainder are in $\mu \mathrm{g} / \mathrm{g}$.

${ }_{2}^{2}$ Average composition includes only particles with $\mathrm{Sm}>12 \mu \mathrm{g} / \mathrm{g}$.

${ }_{3}$ Average of the three basalt particles labeled "other" in Fig. 13

4 Excludes sample 76503,7040 , which has anomalously high concentrations of alkali elements $(\mathrm{Rb}=31 \mu \mathrm{g} / \mathrm{g}, \mathrm{Cs}=1.5 \mu \mathrm{g} / \mathrm{g}, \mathrm{Ba}=264 \mu \mathrm{g} / \mathrm{g})$

${ }^{5}$ Excludes sample 76503,7024 , which has high concentrations of siderophile elements $(\mathrm{Ni}=790 \mu \mathrm{g} / \mathrm{g}, \mathrm{Ir}=33 \mathrm{ng} / \mathrm{g}$ and $\mathrm{Au}=7 \mathrm{ng} / \mathrm{g})$.

For explanation of compositional ranges, see Table 1 .

Mag $=$ magnesían, Gran $=$ granulite, Anorth $=$ anorthositic, Troct $=$ troctolite, Poik $=$ poikilitic, Aphan $=$ aphanitic, $\mathrm{Gl}=$ glass, $\mathrm{Bx}=$ breccia, $\ldots=$ no value, $\#=$ number of particles averaged, mass = combined mass (mg) of particles averaged.

vestiges of relict igneous texture to strongly granoblastic. Compositionally, they typically have moderate to high concentrations of $\mathrm{CaO}(13.5 \%-16.5 \%)$ and siderophile elements $(\mathrm{Ni} \approx 450$ $\mu \mathrm{g} / \mathrm{g}$ on average), and relatively low concentrations of $\mathrm{Sc}(<16$ $\mu \mathrm{g} / \mathrm{g})$ and $\mathrm{Sm}(<3 \mu \mathrm{g} / \mathrm{g})$ (Fig. 8, Tables 2 and A2). Compared to impact-melt breccias, they have high Ir concentrations and $\operatorname{Ir} / \mathrm{Au}$ values. They form a relatively tight cluster on most two-element diagrams, although a few, labeled "anorthositic granulites" in Fig. 8, arc compositionally distinct (e.g., they have higher $\mathrm{CaO}$ and lower $\mathrm{Cr}$ concentrations). The $\mathrm{Sc}-\mathrm{Sm}$ ratio and $\mathrm{Mg}^{\prime}$ distinguish the ferroan and magnesian subsets of granulitic breccias (Fig. 8b, Table A2). There are relatively few ferroan granulitic breccias; all but one of those we have found are from North-Massif samples.

Few of the $2 \mathrm{~mm}-4 \mathrm{~mm}$ lithic fragments have igneous texture and compositions suggesting pristinity. The station- 6 samples have the highest proportion of igneous fragments, but they are mostly of one lithology, magnesian troctolitic anorthosite (Jolliff et al., 1992).
This group of fragments comprises coarsely crystalline plagioclase, plagioclase + olivine ( \pm orthopyroxene), and brecciated equivalents (Table Al). Members of this group form a tight trend (Fig. 8a) or cluster (Fig. 4a) on most two-element diagrams. The mass-weighted mean composition of these particles corresponds to troctolitic anorthosite; these are very similar in mineral chemistry to wellstudied troctolite 76535 (Haskin et al., 1974; Dymek et al., 1975). Igneous fragments of the magnesian suite are scarce in the SouthMassif samples; only one monomict norite fragment was found. Two lithic fragments $(72503,7041$ and 73243,7087$)$ have ITE-poor compositions but relatively high Sc concentrations $(-25 \mu \mathrm{g} / \mathrm{g})$ and appear to be gabbroic breccias. One lithic fragment $(76283,7119)$ is a fragment of alkali anorthosite (Fig. 8), the first such sample found in the Apollo 17 collection.

Seven lithic fragments (three from 72503, two from 73243, and two from 76283) have compositional characteristics similar to those of Apollo 17 ferroan-anorthositic samples whose $\mathrm{Fe} / \mathrm{Mg}$ values are 
TABLE 3. Mass-weighted mean compositions of lithologic groups (interstation comparison).

\begin{tabular}{|c|c|c|c|c|c|c|c|c|c|c|c|c|c|c|c|}
\hline & \multicolumn{4}{|c|}{ Magnesian Granulitic Breccias } & \multicolumn{5}{|c|}{ Poikilitic Melt Breccias, Matrix-Rich ${ }^{I}$} & \multicolumn{5}{|c|}{ Regolith Breccias and Agglutinates } \\
\hline & & 72503 & 73243 & 76503 & 76283 & 72443 & 72503 & 73243 & 76503 & $76283^{2}$ & 72443 & $72503^{3}$ & 73243 & 76503 & $76283^{4}$ \\
\hline $\mathrm{Na}_{2} \mathrm{O}$ & $\%$ & 0.38 & 0.37 & 0.37 & 0.37 & 0.68 & 0.63 & 0.62 & 0.69 & 0.69 & 0.46 & 0.46 & 0.46 & 0.42 & 0.42 \\
\hline $\mathrm{CaO}$ & $\%$ & 14.7 & 15.0 & 15.0 & [5.2 & I1.3 & I 1.5 & 11.1 & I 1.2 & 11.2 & 12.8 & 12.4 & 12.8 & 11.9 & 12.4 \\
\hline $\mathrm{Sc}$ & $\mu \mathrm{g} / \mathrm{g}$ & 7.3 & 6.8 & 8.4 & 7.5 & 17.8 & 17.2 & 17.3 & 15.8 & 16.1 & 21.9 & 18.4 & 20.3 & 27.8 & 30.8 \\
\hline $\mathrm{Cr}$ & $\mu \mathrm{g} / \mathrm{g}$ & 788 & 740 & 830 & 781 & 1390 & 1365 & 1359 & 1283 & 1305 & 1668 & 1512 & 1534 & 1972 & 1960 \\
\hline $\mathrm{FeO}$ & $\%$ & 5.02 & 4.57 & 4.96 & 5.52 & 9.24 & 9.02 & 9.10 & 8.77 & 9.19 & 9.43 & 8.30 & 8.78 & 10.98 & 11.09 \\
\hline Co & $\mu \mathrm{g} / \mathrm{g}$ & 29.0 & 26.8 & 29.6 & 44.5 & 35.4 & 31.5 & 33.1 & 24.4 & 15.9 & 31.0 & 28.2 & 28.9 & 35.4 & $32 . I$ \\
\hline $\mathrm{Ni}$ & $\mu \mathrm{g} / \mathrm{g}$ & 372 & 336 & 362 & 617 & 333 & 292 & 314 & 211 & 107 & 254 & 233 & 241 & 239 & 218 \\
\hline $\mathrm{Zn}$ & $\mu \mathrm{g} / \mathrm{g}$ & 8 & 8 & $3-8$ & 9 & 20 & 16 & 19 & 19 & 18 & 37 & 28 & 37 & $52-54$ & 52 \\
\hline $\mathrm{Rb}$ & $\mu \mathrm{g} / \mathrm{g}$ & 3 & 2 & 3 & 3 & 6 & 7 & 7 & 7 & 8 & 6 & 6 & 6 & 5 & 5 \\
\hline $\mathrm{Sr}$ & $\mu \mathrm{g} / \mathrm{g}$ & 148 & 157 & 155 & 146 & 167 & 165 & 167 & 174 & 183 & 153 & 155 & 156 & 164 & I56 \\
\hline $\mathrm{Zr}$ & $\mu \mathrm{g} / \mathrm{g}$ & 44 & 50 & 43 & $44-48$ & 468 & 450 & 477 & 481 & 487 & 243 & 252 & 237 & 170 & 182 \\
\hline Cs & $\mu \mathrm{g} / \mathrm{g}$ & 0.09 & 0.08 & 0.18 & 0.07 & 0.17 & 0.20 & 0.24 & 0.28 & 0.26 & 0.20 & 0.20 & 0.17 & 0.15 & 0.12 \\
\hline $\mathrm{Ba}$ & $\mu \mathrm{g} / \mathrm{g}$ & 65 & 55 & 61 & 56 & 332 & 335 & 347 & 346 & 344 & 188 & 199 & 177 & 119 & 123 \\
\hline $\mathrm{La}$ & $\mu \mathrm{g} / \mathrm{g}$ & 3.62 & 3.30 & 3.49 & 3.37 & 32.8 & 31.5 & 32.4 & 32.7 & 32.8 & 16.6 & 17.3 & 15.2 & 9.53 & 10.1 \\
\hline $\mathrm{Ce}$ & $\mu \mathrm{g} / \mathrm{g}$ & 9.3 & 8.4 & 8.9 & 8.5 & 84.2 & 81.3 & 84.1 & 84.5 & 85.3 & 43.7 & 45.3 & 40.2 & 25.7 & 27.6 \\
\hline $\mathrm{Nd}$ & $\mu \mathrm{g} / \mathrm{g}$ & 5.3 & 4.9 & 5.0 & 4.8 & 49.8 & 47.4 & 49.5 & 50.0 & 49.5 & 25.3 & 25.9 & 23.5 & 17 & 17.9 \\
\hline $\mathrm{Sm}$ & $\mu \mathrm{g} / \mathrm{g}$ & 1.57 & 1.46 & 1.53 & 1.46 & 15.1 & 14.5 & 14.8 & 15.0 & 15.0 & 8.15 & 8.20 & 7.54 & 5.85 & 6.33 \\
\hline $\mathrm{Eu}$ & $\mu \mathrm{g} / \mathrm{g}$ & 0.83 & 0.84 & 0.85 & 0.86 & 1.88 & 1.84 & 1.82 & 2.01 & 2.03 & 1.34 & 1.29 & 1.30 & 1.32 & 1.33 \\
\hline $\mathrm{Tb}$ & $\mu \mathrm{g} / \mathrm{g}$ & 0.35 & 0.32 & 0.35 & 0.33 & 2.99 & 2.90 & 2.99 & 3.00 & 3.05 & 1.69 & 1.68 & 1.59 & 1.3 & 1.44 \\
\hline $\mathrm{Yb}$ & $\mu \mathrm{g} / \mathrm{g}$ & 1.65 & 1.46 & 1.64 & 1.48 & 10.7 & 10.2 & 10.5 & 10.6 & 10.7 & 6.11 & 6.07 & 5.67 & 4.73 & 5.17 \\
\hline Lu & $\mu \mathrm{g} / \mathrm{g}$ & 0.23 & 0.20 & 0.23 & 0.21 & 1.44 & 1.40 & 1.44 & 1.45 & 1.47 & 0.84 & 0.84 & 0.78 & 0.66 & 0.72 \\
\hline IIf & $\mu \mathrm{g} / \mathrm{g}$ & 1.3 & 1.3 & 1.3 & 1.2 & 11.6 & 11.4 & 11.6 & 11.8 & 11.8 & 6.4 & 6.5 & 6.1 & 5.0 & 5.3 \\
\hline $\mathrm{Ta}$ & $\mu \mathrm{g} / \mathrm{g}$ & 0.23 & 0.25 & 0.20 & 0.18 & 1.54 & 1.48 & 1.50 & 1.50 & 1.52 & 0.86 & 0.84 & 0.79 & 0.74 & 0.81 \\
\hline Ir & $\mathrm{ng} / \mathrm{g}$ & 15.9 & 14.4 & 16.7 & 30.9 & 8.6 & 7.5 & 8.8 & $5.2-6.2$ & $1.9-2.6$ & 8.4 & 7.6 & 8.3 & 8.5 & 7.3 \\
\hline Au & $\mathrm{ng} / \mathrm{g}$ & $5.6-6.0$ & $5.4-5.9$ & $5.7-8.1$ & $9.3-11$ & 5.4 & 4.6 & 5.5 & $3.4-4.1$ & $1.7-2.1$ & 3.8 & 3.0 & 4.1 & 2.9 & 2.6 \\
\hline Th & $\mu \mathrm{g} / \mathrm{g}$ & 1.02 & 0.96 & 0.88 & 0.81 & 5.08 & 4.99 & 5.31 & 5.12 & 5.16 & 2.78 & 3.00 & 2.51 & 1.51 & 1.58 \\
\hline U & $\mu \mathrm{g} / \mathrm{g}$ & 0.29 & 0.28 & 0.26 & 0.25 & 1.36 & 1.37 & 1.42 & 1.44 & 1.37 & 0.74 & 0.82 & 0.71 & 0.44 & 0.43 \\
\hline \multicolumn{2}{|c|}{ No. particles } & 11 & 9 & II & 15 & 22 & 84 & 23 & 38 & II & 31 & 57 & 27 & 96 & 65 \\
\hline \multicolumn{2}{|c|}{$\Sigma$ mass $(\mathrm{mg})$} & 283 & 305 & 284 & 482 & 611 & 226 & 471 & 693 & 228 & 464 & 762 & 614 & 1447 & 1640 \\
\hline
\end{tabular}

${ }_{1}^{1}$ Only particles with $\mathrm{Sm}>12 \mu \mathrm{g} / \mathrm{g}$ included in average.

2 Two siderophile-element-rich melt breccias were excluded from the average: $76283,7142(\mathrm{Co}=244 \mu \mathrm{g} / \mathrm{g}, \mathrm{Ni}=3080 \mu \mathrm{g} / \mathrm{g}, \mathrm{Ir}=66 \mathrm{ng} / \mathrm{g}, \mathrm{Au}=53 \mathrm{ng} / \mathrm{g})$ and $76283,7152(\mathrm{Co}=165 \mu \mathrm{g} / \mathrm{g}, \mathrm{Ni}=1910 \mu \mathrm{g} / \mathrm{g}, \mathrm{Ir}=58 \mathrm{ng} / \mathrm{g}, \mathrm{Au}=35 \mathrm{ng} / \mathrm{g})$.

3 Siderophile-element-rich agglutinate $72503,7010(\mathrm{Co}=79 \mu \mathrm{g} / \mathrm{g}, \mathrm{Ni}=1260 \mu \mathrm{g} / \mathrm{g}, \mathrm{Ir}=56 \mathrm{ng} / \mathrm{g}, \mathrm{Au}=13 \mathrm{ng} / \mathrm{g})$ excluded from average.

${ }^{4}$ Siderophile-element-rich breccia $76283,7112(\mathrm{Co}=221 \mu \mathrm{g} / \mathrm{g}, \mathrm{Ni}=2990 \mu \mathrm{g} / \mathrm{g}, \mathrm{Ir}=151 \mathrm{ng} / \mathrm{g}, \mathrm{Au}=49 \mathrm{ng} / \mathrm{g})$ excluded from average.

For explanation of compositional ranges, see Table $\mathrm{I}$.

TABLE 4. Mass-weighted mean major-element compositions of lithologic groups from 76503 and 72503.

\begin{tabular}{|c|c|c|c|c|c|c|c|c|c|c|}
\hline & \multicolumn{2}{|c|}{ Magnesian Granulites } & \multirow{2}{*}{$\begin{array}{l}\text { Ferroan } \\
\text { Granulites } \\
76503\end{array}$} & \multicolumn{2}{|c|}{$\begin{array}{l}\text { Poikilitic Melt Breccia } \\
\text { Matrix-rich }\end{array}$} & \multicolumn{2}{|c|}{$\begin{array}{l}\text { Aphanitic Melt Breccia } \\
\text { Matrix-rich }\end{array}$} & \multicolumn{2}{|c|}{ ITE-rich Melt Breccia } & \multirow{2}{*}{$\begin{array}{c}\begin{array}{c}\text { Orange } \\
\text { Glass Bx }\end{array} \\
76503\end{array}$} \\
\hline & 76503 & 72503 & & 76503 & 72503 & 76503 & 72503 & 76503 & 72503 & \\
\hline $\mathrm{SiO}_{2}$ & 45.0 & 44.4 & 44.5 & 46.4 & 46.4 & 46.6 & 46.3 & 47.8 & 47.0 & 39.2 \\
\hline $\mathrm{TiO}_{2}$ & 0.22 & 0.25 & 0.22 & 1.57 & 1.59 & 0.66 & 0.65 & 1.91 & 1.36 & 8.40 \\
\hline $\mathrm{Al}_{2} \mathrm{O}_{3}$ & 26.7 & 25.7 & 25.7 & 17.6 & 19.13 & 21.8 & 22.3 & 16.5 & 17.9 & 7.21 \\
\hline $\mathrm{Cr}_{2} \mathrm{O}_{3}$ & 0.12 & 0.13 & 0.12 & 0.20 & 0.19 & 0.18 & 0.20 & 0.20 & 0.21 & 0.69 \\
\hline $\mathrm{FeO}$ & 4.52 & 5.13 & 6.70 & 8.91 & 8.31 & 7.39 & 6.78 & 9.83 & 10.1 & 21.3 \\
\hline $\mathrm{MnO}$ & 0.07 & 0.07 & 0.09 & 0.12 & 0.12 & 0.10 & 0.09 & 0.13 & 0.14 & 0.26 \\
\hline $\mathrm{MgO}$ & 7.49 & 8.83 & 6.18 & 12.7 & 11.5 & 8.61 & 10.0 & 10.6 & 10.4 & 14.1 \\
\hline $\mathrm{CaO}$ & 15.5 & 14.7 & 15.4 & 10.9 & 11.6 & 13.2 & 12.7 & 11.0 & 11.2 & 7.96 \\
\hline $\mathrm{Na}_{2} \mathrm{O}$ & 0.33 & 0.34 & 0.35 & 0.64 & 0.63 & 0.51 & 0.48 & 0.81 & 0.64 & 0.47 \\
\hline $\mathrm{K}_{2} \mathrm{O}$ & 0.07 & 0.08 & 0.03 & 0.23 & 0.21 & 0.14 & 0.19 & 0.35 & 0.29 & 0.08 \\
\hline $\mathrm{P}_{2} \mathrm{O}_{5}$ & 0.03 & 0.03 & 0.03 & 0.24 & 0.23 & 0.15 & 0.17 & 0.35 & 0.34 & 0.04 \\
\hline Total & 100.1 & 99.7 & 99.3 & 99.5 & 99.9 & 99.3 & 99.9 & 99.5 & 99.6 & 99.7 \\
\hline Mg' & 0.75 & 0.75 & 0.62 & 0.72 & 0.71 & 0.68 & 0.73 & 0.65 & 0.65 & 0.54 \\
\hline \# & 5 & 2 & 2 & 10 & 4 & 2 & 3 & 2 & 6 & 4 \\
\hline mass (mg) & g) 83 & 108 & 30 & 159 & 328 & 35 & 132 & 41 & 171 & 67 \\
\hline
\end{tabular}

$\mathrm{Mg}^{\prime}=\operatorname{molar} \mathrm{MgO} /(\mathrm{MgO}+\mathrm{FeO})$ 

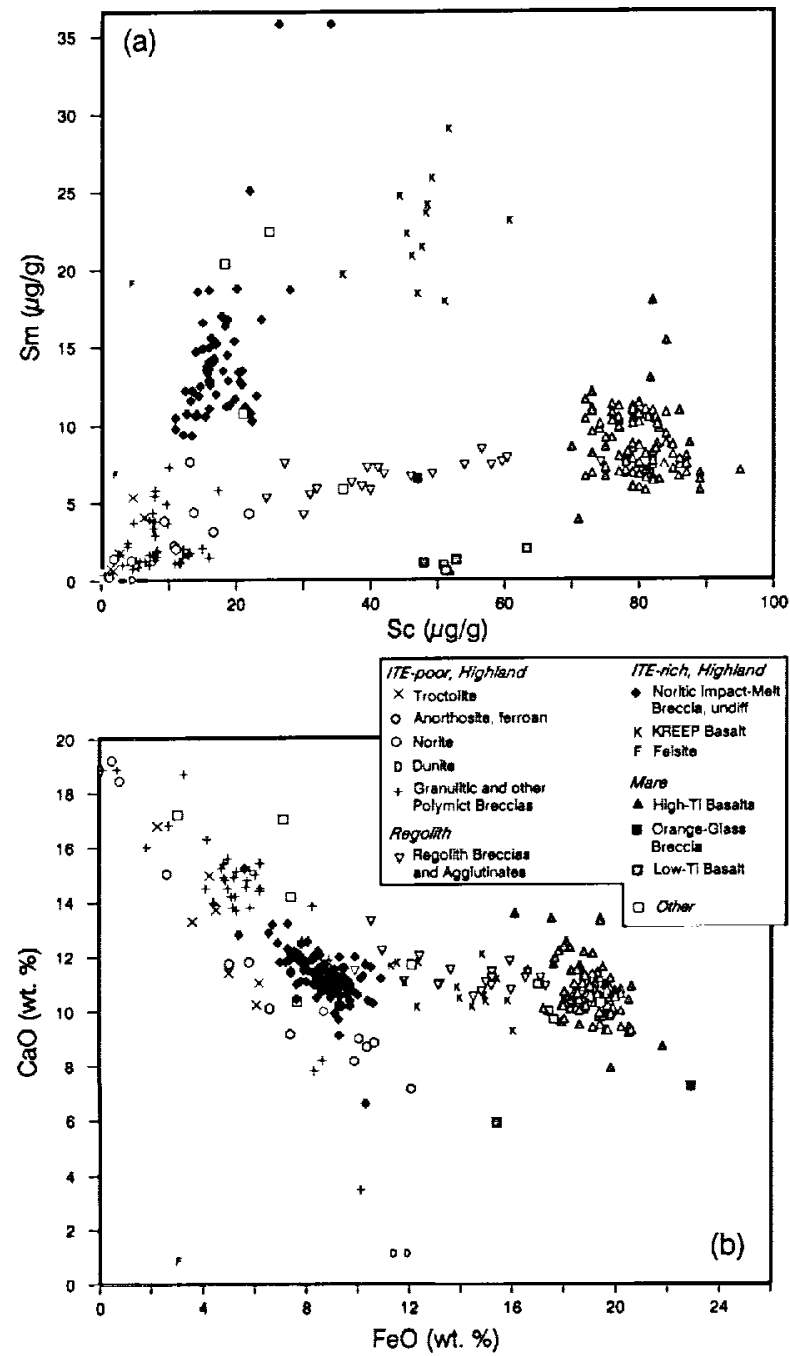

FIG. 7. Compositions of large ( $>5 \mathrm{~g}$ ) Apollo 17 samples, taken from the literature. Subsamples and clasts from large samples are included. (a) Concentrations of $\mathrm{Sc} v s$. Sm; (b) $\mathrm{FeO}$ vs. $\mathrm{CaO}$. The ITE-poor highland rock types are divided into pristine igneous rocks (ferroan anorthosite, troctolite, dunite, and norite) and granulitic breccias. KREEP basalt and felsite are noted by the symbols $\mathrm{K}$ and $\mathrm{F}$, respectively. Sources of these data are many and are found among those cited in the reference list.

known. These samples have high $\mathrm{CaO}$ concentrations (e.g., $\geq 18 \%$ ) and low $\mathrm{Cr} / \mathrm{Sc}$ ratios (generally $<75$, Fig. $8 \mathrm{~b}$ ). Their REE concentrations are greater than the REE concentrations of Apollo 16 ferroan anorthosites but are similar to other Apollo 17 anorthosites (Fig. 9). Their Eu concentrations range from $0.7 \mu \mathrm{g} / \mathrm{g}$ to $1.4 \mu \mathrm{g} / \mathrm{g}$; only one particle has $\mathrm{Eu}>1 \mu \mathrm{g} / \mathrm{g}$. This range is similar to that for anorthosites from Apollo $16(\sim 0.8 \mu \mathrm{g} / \mathrm{g}$ to $1.0 \mu \mathrm{g} / \mathrm{g} ; e . g$, Haskin et al., 1981). The Eu concentrations of other Apollo 17 ferroan anorthosites range from $0.87 \mu \mathrm{g} / \mathrm{g}$ to $2.06 \mu \mathrm{g} / \mathrm{g}$ (Warren et al., 1991). The highest concentration of $2.06 \mu \mathrm{g} / \mathrm{g}$ belongs to a "questionably pristine" sample of a "relatively evolved variety of ferroan anorthosite" (Warren et al., 1986), although even one "unambiguously pristine" sample $(74114,5)$ has a high Eu concentration $(1.4 \mu \mathrm{g} / \mathrm{g}$; Warren et al, 1991) compared to Apollo 15 and 16 ferroan anorthosites. All of the $2 \mathrm{~mm}-4 \mathrm{~mm}$ ferroan-anorthositic lithic fragments consist of polygranular plagioclase with brecciated or
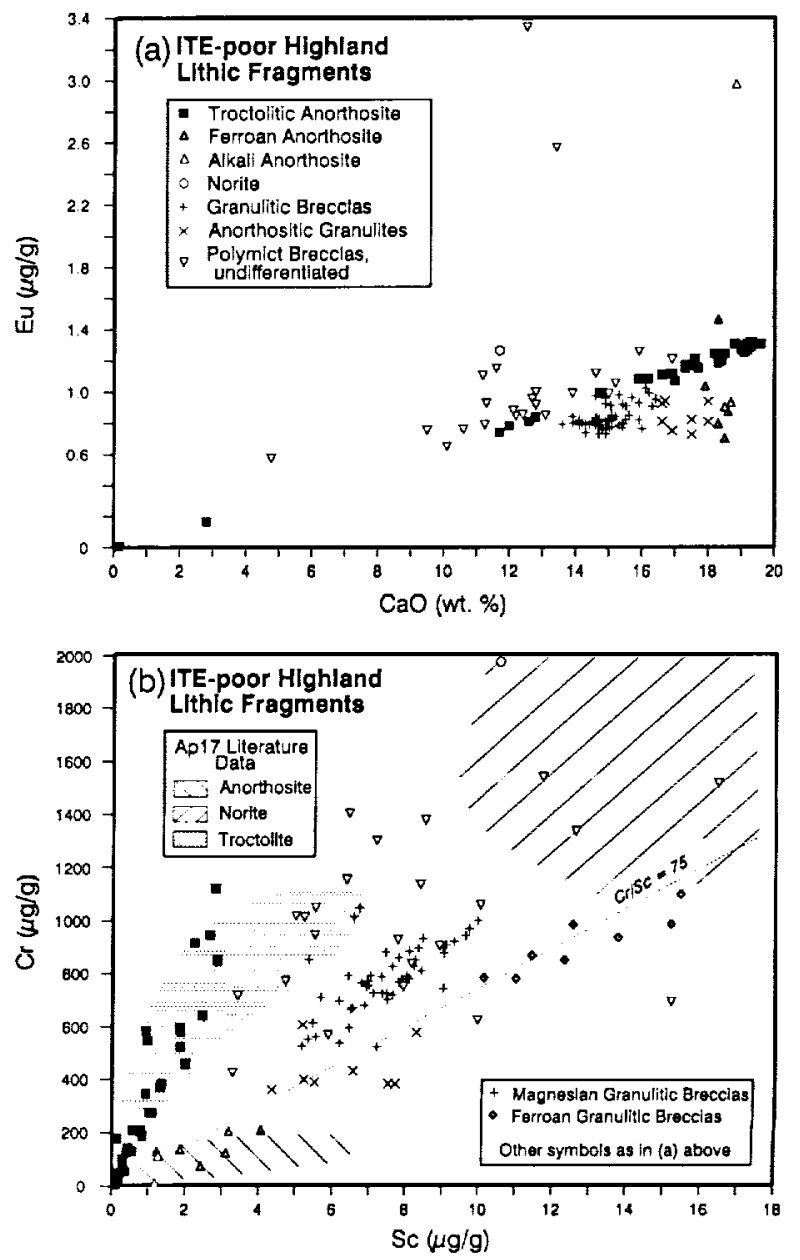

FIG. 8. Compositions of ITE-poor ( $\mathrm{Sm}<3.5 \mu \mathrm{g} / \mathrm{g}$ ) highland lithic fragments from samples $72443,72503,73243,76283$, and 76503 . (a) $\mathrm{Eu}$ v. $\mathrm{CaO}$ concentrations showing the tight trend of troctolitic-anorthosite fragments (mixing line between olivine with essentially no Eu and very little $\mathrm{CaO}$ and plagioclase of fixed $\mathrm{Eu}$ and $\mathrm{CaO}$ concentrations). Granulitic breccias form a tight cluster at $\sim 15 \mathrm{wt} \% \mathrm{CaO}$ and $0.8 \mu \mathrm{g} / \mathrm{g}$ Eu. Samples labeled "polymict breccias, undifferentiated" include polymict breccias and breccias with compositions that do not correspond to any known ITE-poor highland lithology. (b) Sc vs. Cr concentrations comparing ITE-poor lithic fragments from this study with compositional fields of Apollo 17 samples from the literature. The $\mathrm{Cr} / \mathrm{Sc}$ values tend to correlate with $\mathrm{Mg} / \mathrm{Fe}$. Several lithic fragments have low $\mathrm{Cr} / \mathrm{Sc}$ values $(\leq 75)$ typical of ferroan-suite samples. For contrast, the highly magnesian troctolitic-anorthosite fragments (all from station- 6 samples) have high $\mathrm{Cr} / \mathrm{Sc}$ values. Igneous fragments with the composition of norite as defined by literature data are scarce among the $2 \mathrm{~mm}-4 \mathrm{~mm}$ lithic fragments. Most of those whose compositions plot within the norite compositional field are polymict breccias.

granulitic textures. Compositions of coexisting plagioclase (An) and mafic silicates $\left(\mathrm{Mg}^{\prime}\right)$ from three of these samples confirm ferroan mineralogy, although two lie near the magnesian end of the ferroan-anorthositic suite.

In addition to igneous fragments and granulitic breccias, there is a significant number (23) of lithic fragments that have low ITE concentrations (labeled "polymict breccias, undifferentiated" in Figs. 8, 10). These fall into three broad groups, as follows: (1) mixed lithologies, such as regolith breccias with coarse anorthositic clasts, or granulitic breccias with observable clasts or adhering but 


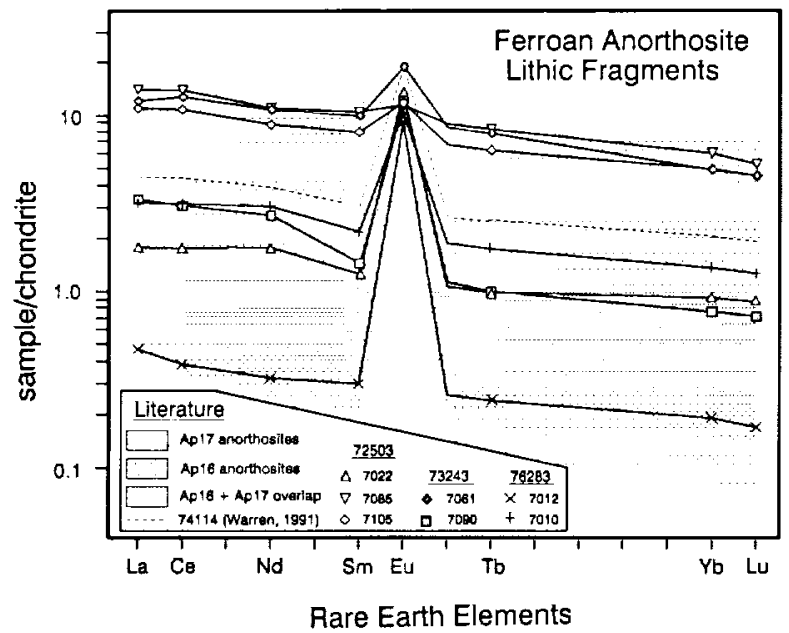

FIG. 9. Concentrations of rare carth elements, normalized to volatile-free $\mathrm{CI}$ chondrites, of anorthositic lithic fragments. The chondrite values are those of Anders and Grevesse (1989) multiplied by 1.36. Heavy lines show REE concentrations of seven anorthositic fragments, five from South Massif and two from North Massif, discovered in this study. The stippled patterns show the range of REE concentrations of Apollo 16 and Apollo 17 ferroananorthositic-suite (FAS) samples that are listed in the compilation of pristine samples by Warren (1993) (compositional data taken from references given therein). There are many Apollo 16 anorthosites, but the plotted range includes only FAS samples with strong evidence of pristinity (i.e., Warrens's confidence class 8 or greater). The plotted Apollo 17 range includes all 10 Apollo 17 FAS samples listed by Warren (1993). The pristinity of most Apollo 17 FAS samples is questionable. The REE pattern of one "unambiguously pristine" ferroan anorth-osite ,74114,5, (Warren et $a l, 1991)$ is shown by the light dashed line. The REE concentrations of six of the $2 \mathrm{~mm}-4 \mathrm{~mm}$ anorthositic fragments are within the range of Apollo 17 anorthosites from the literature, and one $(76283,7012)$ has lower REE concentrations than any Apollo 17 anorthosite yet reported.

dissimilar breccia, and which, therefore, have anomalous compositions compared to prominent breccia groups; (2) breccias, dark and glassy to light colored and coarsely crystalline, that have high to exceptionally high $\mathrm{Na}_{2} \mathrm{O}$ and Eu concentrations indicative of alkalianorthosite or alkali-norite components; and (3) white, friable to glassy-textured breccias. The white, friable breccias are an abundant subgroup of the "undifferentiated" category and form a diffuse compositional cluster. They differ from the granulitic breccias by lower $\mathrm{CaO}$ concentrations $(<14 \%)$ and by higher $\mathrm{Eu} / \mathrm{CaO}$ and $\mathrm{Cr} / \mathrm{Sc}$ ratios (Fig 8). Most of the white, friable breccias have relatively low siderophile-element concentrations (e.g., $\mathrm{Ni}<100 \mu \mathrm{g} / \mathrm{g}$ ). In thin section, several of these are clast-rich, containing a diversity of clast types, and have glassy matrices; some appear to be fragments of immature regolith breccias (e.g., 76503,7069, $\mathrm{Sc}=7.2, \mathrm{Sm}=3.1$ $\mu \mathrm{g} / \mathrm{g}$ ) or melt/fragmental breccia of a single precursor (e.g., "troctolitic" breccia 76503,7057, Table A1).

As first mentioned in the section on regolith breccias, there is a group of fragmental to glassy-matrix lithic fragments, found mainly at station 6, that are distinguished from the white, friable breccias by higher ITE concentrations (e.g., $4 \mu \mathrm{g} / \mathrm{g}-7 \mu \mathrm{g} / \mathrm{g} \mathrm{Sm}$ ). These fragmental breccias are an important subset of the regolith breccias because they lack a mare component (e.g., they have low $\mathrm{Cr}$ and $\mathrm{Sc}$ concentrations), and from petrographic examination of a subset of these particles, they appear to lack the poikilitic melt-breccia components thought to be basin-related melt breccias. If the poikilitic melt breccias are from the Serenitatis event, then we consider these regolith breccias to be representative of the preSerenitatis surface (see also Jolliff and Bishop, 1993). The compo-

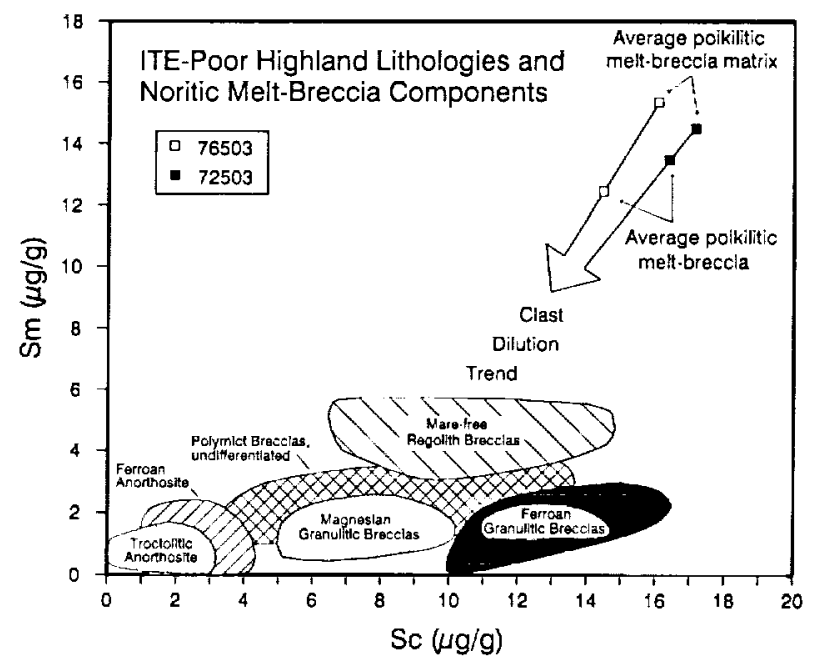

FIG. 10. Concentrations of Sc vs. Sm of highland rock types from samples $72443,72503,73243,76283$, and 76503 . The average "poikilitic meltbreccia matrix" compositions of 76503 and 72503 are the mean compositions of the tight clusters of compositions shown in Figs. 4a, 5a $(\sim 15-19 \mu \mathrm{g} / \mathrm{g} \mathrm{Sc}$ and $13-17 \mu \mathrm{g} / \mathrm{g} \mathrm{Sm})$ and are taken to be representative of the melt matrix of the poikilitic groups of impact-melt breccias (IMBs) at stations 6 and 2. Melt-breccia lithic fragments that have lower Sm concentrations than the matrix-rich ones form a diffuse "trend" between the matrix-rich IMB compositions and those of the ITE-poor rock types; we attribute this mainly to clast dilution (i.e., dilution of the $\mathrm{Sm}$ - and $\mathrm{Sc}$-rich matrix composition by clasts that have low concentrations of these elements, especially Sm). When we include the compositions of the meltbreccias that have relatively low $\mathrm{Sm}$ concentrations, the average composition of the IMBs lies between the matrix-rich composition and the average composition of the ITE-poor rock types (excluding troctolitic anorthosite), which falls in the magnesian-granulite field. Thus, it appears that the highland clast component of the IMBs is similar, on average, to the ITE-poor highland lithologies (excluding the troctolitic anorthosite, which is enriched anomalously in 76503). From this, we infer that the ITE-poor highland lithologies represented in these samples are largely representative of the upper-crustal materials in the target region of the impact basin.

sitional trend of the noritic impact-melt breccias resulting from "dilution" with clasts of relatively anorthositic, ITE-poor highland lithologies extrapolates through the compositions of these mare-free regolith breccias and into the field of granulitic-breccia compositions, as illustrated in Fig. 10. If the clasts in the impact-melt breccias are the same rock types as the ITE-poor highland lithologies, then small fragments of the impact-melt breccias that are clast rich should have compositions trending toward the ITE-poor highland lithologies. In fact, the "clast-dilution" trend extrapolates approximately to the mean composition of all of the ITE-poor highland lithologies, minus the abundant group of troctoliticanorthosite fragments from 76503, which, although they may be one of the melt-breccia clast components, appear to be disproportionately represented in that sample. We take this as evidence that, to first order, the ITE-poor regolith breccias represent the surface and the granulitic breccias represent the upper crust that dominated the pre-Serenitatis region.

\section{Impact-Melt Breccias}

Apollo 17 impact-melt breccias are noritic in bulk composition and are the major carriers of ITEs in the regolith. They have been classified into aphanitic- and poikilitic-matrix groups based on a combination of petrographic and compositional characteristics (Spudis and Ryder, 1981). The majority of impact-melt breccias for 
which data appear in the literature belong to the compositionally tight poikilitic group. The aphanitic melt-breccia group is compositionally more variable and differs from the poikilitic group by lower $\mathrm{TiO}_{2}$ and higher $\mathrm{Al}_{2} \mathrm{O}_{3}$ concentrations (Spudis and Ryder, 1981; Ryder, 1992b; and this work, Table 4). The aphanitic breccias are typically clast-rich relative to the poikilitic breccias, and the lithologic distribution of clasts differs (James et al, 1978; Spudis and Ryder, 1981). Clasts in the poikilitic melt breccias are mainly granulites and plutonic norites and troctolites (e.g., Simonds, 1975; Dymek et al., 1976). In addition to these clast types, aphanitic melt breccias contain clasts of felsite, basalt, and feldspathic breccias (Ryder et al., 1975a; Blanchard ef al, 1977; Blanchard and Budahn, 1979). All of the large-rock samples of aphanitic melt breccia are from the South Massif, but poikilitic melt-breccia boulders occur at the base of both massifs

About $70 \%$ of the $2 \mathrm{~mm}-4 \mathrm{~mm}$ particles from the South-Massif samples are fragments of noritic impact-melt breccias, compared to only $25 \%$ of those from the North-Massif samples. At both massifs, most melt-breccia particles are of the poikilitic type, we base this finding on compositional characteristics and examination of thin sections prepared from 76503 and 72503 (this study) and related 1 mm-2 mm particles (Blanchard et al, 1975 ). The poikilitic-matrix group generally forms a tight compositional trend between a mafic, ITE-rich melt and ITE-poor highland rock types (e.g., Fig. 4a). Poikilitic melt breccias from North and South Massifs (Table A3a) show similar compositional variability, presumably due to variable clast contents, but their mean compositions are significantly different (e.g., Na, Eu, Sc, Cr, Ni; see Fig. II and Table 2). Their compositional differences suggest broad heterogeneities in the ejected basin impact melt (Rockow et al, 1994b).

A few of the melt-breccia lithic fragments from station 3 and $-10 \%$ of those from station 2 have aphanitic texture and compositions typical of the aphanitic group known from the literature. $A$

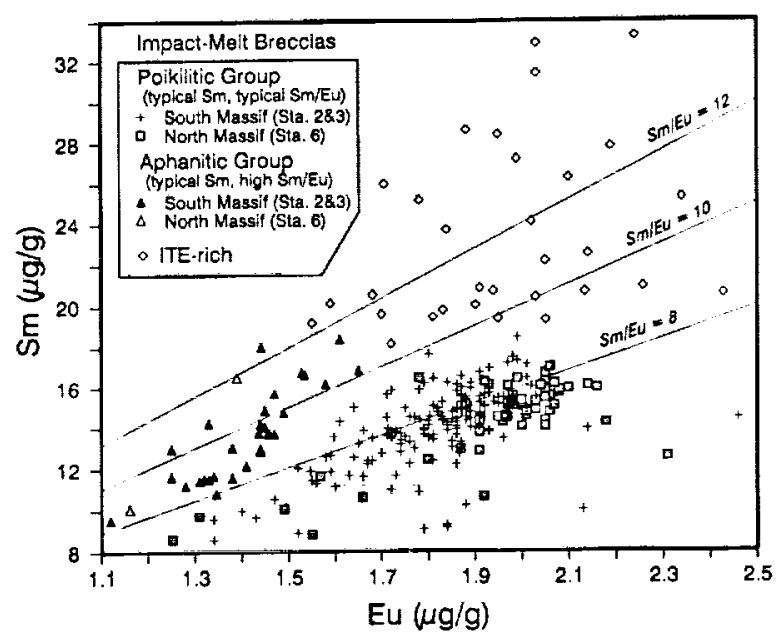

FiG. 11. Concentrations of Eu vs. Sm of noritic impact-melt breccias from samples $72443,72503,73243,76283$, and 76503 . Samples are divided into three main groups: (1) "typical $\mathrm{Sm}$, typical Sm/Eu" (Sm/Eu mostly < 9), which corresponds to the poikilitic melt-breccia group; (2) "typical Sm, high $\mathrm{Sm} / \mathrm{Eu} "(\mathrm{Sm} / \mathrm{Eu}-8-12)$, corresponding to the aphanitic melt group (all from South Massif except for the two indicated); and (3) "ITE-rich" (mostly from South Massif). The poikilitic group comprises samples from both massifs, but samples from the two massifs cover slightly different compositional distributions, thus they are distinguished by two different symbols. few of the lithic fragments from station 6 also belong to the aphanitic group and are the first of this group in a North-Massif sample. Previously, members of the aphanitic group have been distinguished compositionally from those of the poikilitic group by their low $\mathrm{TiO}_{2}$ concentrations ( $\leq 1.2 \mathrm{wt} \%$, Spudis and Ryder, 1981 ). Our data show that they can also be distinguished by lower $\mathrm{Na}_{2} \mathrm{O}$, $\mathrm{Eu}$, and $\mathrm{Sr}$ concentrations relative to their ITE concentrations (Tables 2, A2c, Fig. 11), which suggests a significantly different average plagioclase component, one that is more albitic in the poikilitic melts. Megascopically, the aphanitic breccias differ from the poikilitic breccias by their finer grain size, darker color, and a general lack of vesicles.

In addition to the aphanitic and poikilitic breccias, we have found a third compositionally distinct group of melt breccias among the soil particles that is characterized by ITE-rich compositions, which we define as $>18 \mu \mathrm{g} / \mathrm{g} \mathrm{Sm}$ (Tables 2, A3b). We chose 18 $\mu \mathrm{g} / \mathrm{g} \mathrm{Sm}$ as a cutoff for the following rcasons: (1) Subsamples of the large, well-characterized melt breccias (boulder samples) have $\mathrm{Sm}$ concentrations that do not exceed $\sim 17 \mu \mathrm{g} / \mathrm{g} \mathrm{Sm}$ (much litcraturc data). (2) For all melt breccias among the $2 \mathrm{~mm}-4 \mathrm{~mm}$ particles, there is a compositional hiatus at $\sim 18 \mu \mathrm{g} / \mathrm{g} \mathrm{Sm}$. This is mainly a compositional classification; a few previously analyzed Apollo 17 samples also have $\mathrm{Sm}>18 \mu \mathrm{g} / \mathrm{g}$; perhaps future studies will subdivide these melt breccias on the basis of different ages, textures, or mineral and lithic components.

Compared to the other melt-breccia groups, the ITE-rich breccias have lower $\mathrm{Cr} / \mathrm{Sc}$ ratios (average $=71$ ) than either the poikilitic or aphanitic breccias (average $=79$ and 87 , respectively) but high $\mathrm{Sm} / \mathrm{F} u$ ratios, similar to the aphanitic breccias (Fig. 11). On most two-element plots, these samples do not cluster tightly but are dispersed over a substantial range; thus, we use the term "compositional group" loosely. The ITE-rich melt breccias mostly have dark, glassy to cryptocrystalline matrices, although some have fine- to medium-grained poikilitic texture. All have fine-grained to very fine-grained, evenly disseminated ilmenite; their matrix is unquestionably of melt origin. Their bulk $\mathrm{Mg}^{\prime}$ values are lower than those of either the poikilitic or aphanitic groups (Table 4), which suggests that the target rocks were more cvolved on average. They contain a moderate proportion of dominantly single-mineral clasts, but some have relatively large feldspathic lithic clasts.

Although impact-melt breccias of this composition have not been distinguished previously as a group, several samples with similar compositions have been analyzed (samples 76224,15 and 76264,7; Laul et al., 1989), and Spudis and Ryder (1981) have suggested that two "KREFP-rich" rake samples might represent a third group of Apollo 17 melt breccias. Sample 72735, a $51 \mathrm{~g}$ impact-melt breccia, has relatively high ITE concentrations $(\mathrm{Sm} \approx$ $19 \mu \mathrm{g} / \mathrm{g}$ ), but its composition differs from those of the particles we have found because of its unusually high $\mathrm{K}_{2} \mathrm{O}\left(\mathrm{K}_{2} \mathrm{O}>\mathrm{Na}_{2} \mathrm{O}\right)$, low $\mathrm{TiO}_{2}$ concentration and high $\mathrm{La} / \mathrm{Sm}$ ratio (Murali et $\mathrm{al}$., 1977 , in Ryder, 1993). As a group, compositions (and compositional variability) of these ITE-rich melt breccias are most similar to those of melt group B from Apollo 15 (Ryder and Spudis, 1987; Ryder et al., 1988; Fig. 12). Some significant compositional differences exist, however, between the ITE-rich breccias from Apollo 17 and the Apollo 15 group-B breccias (e.g., the $\mathrm{Na}$ and $\mathrm{Cr}$ concentrations do not overlap). Also, subtle compositional differences exist between these groups in their average ITE interclement ratios involving the alkali elements, the REE, and $\mathrm{Zr}$ and IIr. We defer more detailed discussion of this group of melt breccias to a subsequent paper. 


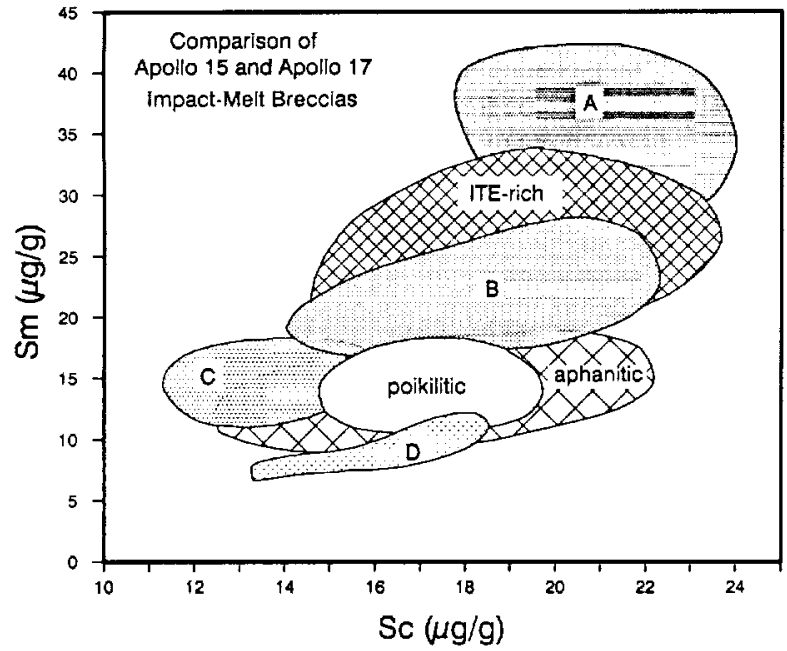

FIG. 12. Comparison of Apollo 15 and Apollo 17 impact-melt breccia compositions. $\Lambda$ pollo 15 melt breccias have been subdivided into five groups (Ryder and Spudis, 1987); four of the groups are shown (A, B, C, $D)$. Note the overlap between Apollo 15 type $B$ melt breccias and the Apollo 17 ITE-rich group. Apollo 15 data are from Ryder and Spudis (1987), Laul et al. (1988), Lindstrom et al. (1988), and Ryder et al. (1988). The Apollo 17 data are from this work. The Apollo 17 poikilitic field excludes melt breccias with $<10 \mu \mathrm{g} / \mathrm{g} \mathrm{Sm}$ (i.e., mainly the clast-rich samples).

\section{High-Titanium Mare Basalts}

Early investigators of Apollo 17 high-Ti basalts distinguished three groups (groups $A, B$, and $C$ ) on the basis of geochemical parameters, such as $\mathrm{Ba} / \mathrm{Rb}, \mathrm{La} / \mathrm{Yb}$ and $\mathrm{Sr} / \mathrm{Rb}$ ratios (Rhodes et al., 1976). Recently, Neal et al. (1990) split group B into B1 and B2 based on REE ratios, and Ryder (1990) designated a unique basalt particle as "type D." Type D is characterized by higher $\mathrm{MgO}$ and $\mathrm{Cr}_{2} \mathrm{O}_{3}$ and lower REE, TiO, $\mathrm{Sc}$, and $\mathrm{CaO} / \mathrm{Al}_{2} \mathrm{O}_{3}$ (Ryder, 1990). Samples of groups $\mathrm{A}$ and $\mathrm{B}$ are abundant and come from many sample locations on the valley floor. The few group C samples are mostly from the arca around Shorty crater (Wolfe et al., 1981). The type-D basalt sample is from the regolith core taken at station 9 (Van Serg crater). Petrographically, three main types of basalt have been distinguished: olivine-porphyritic ilmenite basalt, plagioclasepoikilitic ilmenite basalt, and a type similar to Apollo- 11 low-K basalt. I Towever, these do not correspond to the compositional groups; all petrographic types can be found within each compositional group (Neal and Taylor, 1992).

Comparing compositions of the $2 \mathrm{~mm}-4 \mathrm{~mm}$ basaltic fragments found in the highland soils of this study to compositions of known Apollo 17 basalt groups (Fig. 13), we find that $-35 \%$ of the basalt particles belong to group $\Lambda, 20 \%$ to group $B 2$, a few $(\sim 2 \%)$ to $B 1$; $\sim 4 \%$ are not easily assigned, on the basis of composition alone, to one of the known groups. Of the latter, two have compositional affinities to group $\mathrm{C}$, and three fine-grained to glassy particles of similar composition to each other share some compositional features with the type-D sample. Two of those similar to type D are from station 6 and one is from station 3. The remaining 29 particles are too coarse grained to be modally representative of the larger rock from which they derive (similar to group "U" of Rhodes et al., 1976; see also Haskin and Korotev, 1977), although compositions of several of these are consistent with group B1.
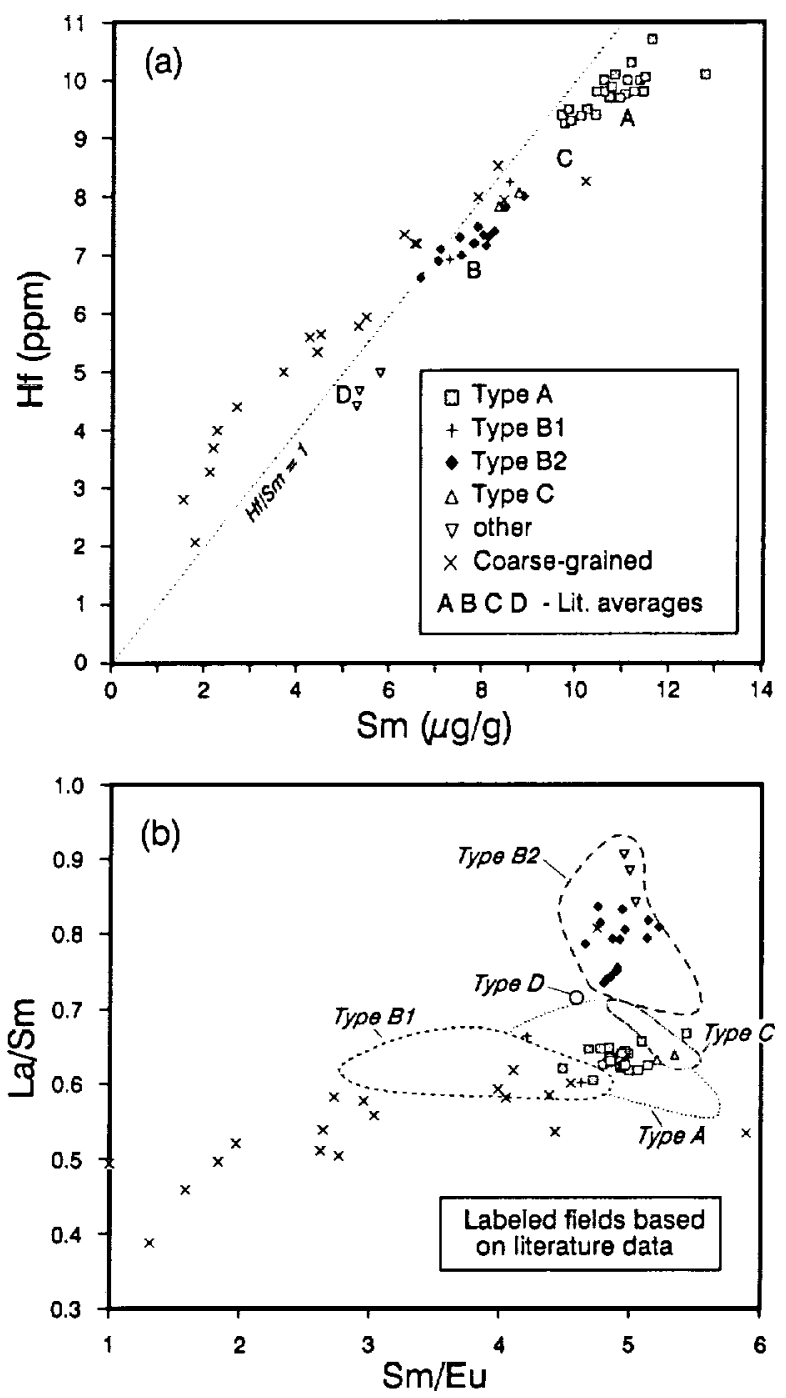

FIG. 13. Comparison of compositions of high-Ti basalt fragments from this study to those of basalts from the literature. (a) Hf $v s$. Sm concentrations. The letters $A, B$, and $C$ represent the average compositions of the three basalt groups of Rhodes et al. (1976) and D is the composition of a unique basalt sample reported by Ryder (1990). (b) Sm/Eu vs. La/Sm. Most of the fine-grained basalt particles can be assigned to known groups (A, B1, B2, and $C$ ). Three lithic fragments, labeled "other," have not been assigned to a group although they share some compositional characteristics with group D. Most of the coarse-grained lithic fragments have low incompatible-element concentrations and are probably cumulates, not modally representative of the rock from which they derive (similar to class "U" of Rhodes et al., 1976), although a few fall consistently within the B1 field.

Fragments of mare basalt are abundant at station 6 and generally scarce in the South-Massif samples, particularly at station 2 (Figs. 4, $5)$. This is consistent with the proximity of station 6 to the valleyfloor craters Henry, Shakespeare, and Cochise. Presumably, the South-Massif basalts originated farther out on the valley floor because craters that have penetrated the light mantle are scarce (Wolfe et al., 1981). That there are so few basalts at stations 2 and 3 suggests that mixing on the light mantle since its emplacement $\sim 100 \mathrm{Ma}$ ago (Arvidson et al., 1976; Wolfe et al., 1981) has been minor. Based on the overall population of $2 \mathrm{~mm}-4 \mathrm{~mm}$ basalt 
particles, the distribution of basalt groups found in these predominantly highland soils is similar to that observed from the large rock samples from the valley floor (see Neal and Taylor, 1993); groups A and B (mainly B2) are abundant and group C is rare. However, difficulty in classifying many of the small, coarsegrained samples found in 76503 and 76283 biases the distribution. For example, it appears that BI samples typically may be coarser grained than the others and, thus, may be underrepresented in our estimate.

\section{Low-Titanium Basalts}

Very-low-Ti (VLT) basalts, defined generally as having $<1$ wt \% $\mathrm{TiO}_{2}$, have been found among the Apollo 17 samples, but not as large rocks. Some VLT basalt has been found as fragments in the Apollo 17 deep drill core (Vaniman and Papike, 1977; Wentworth et al., 1979) and as clasts in impact-melt breccias 78526 (Warner $e t$ al., 1978), 73255 (James and McGee, 1980), and 72215 and 72235 (Ryder et al., 1975a). Although VLT basalts are rare in the sample collection, mass-balance constraints for $\mathrm{Ti}$ in soils indicate that some type of low-Ti basalt must be a significant (but $<10 \%$ ) component of the regolith of the valley floor (Korotev and Kremser, 1992). Indeed, three different groups of glass of VLT-basalt composition were found among $-100 \mu \mathrm{m}$ glass fragments in the regolith at station 9 (Lindstrom et al, 1994), but their source is unclear. Spectral reflectance data suggest that low-Ti basalts occur in the central regions of the Serenitatis basin and along its northeastern edge (Pieters, 1978). Other than having low Ti concentrations, VLT-basalt samples exhibit a range of compositions as well as textures.

We have found one lithic fragment in each of samples 72443 , 72503,76503 , and two in 73243 that have compositional similarities to previously reported VIT basalts (moderately high $\mathrm{Sc}$ and $\mathrm{FeO}$, very low REEs). Their REE patterns are variable, ranging from LREE depleted to slightly enriched (Fig. 14). Macroscopically, three of the particles appear brecciated and two have coarse-grained, equigranular igneous textures. One of the samples, 76503,7040 , has relatively high concentrations of alkali elements (e.g., $0.8 \% \mathrm{~K}_{2} \mathrm{O}$; Table A5), which is similar to Apollo 12 high-K basalt. It has a relatively fine-grained, brecciated texture and abundant, finely exsolved augite.

\section{Orange and Black Volcanic Glass}

Spheres and broken fragments of orange and black glass have been found in most soils from Apollo 17 (Heiken et al., 1974) and, in some places, constitute entire soil horizons (sample 74220 and core 74001/2). The compositions and morphologies of these glasses are consistent with an origin by fire-fountaining of primary, mantlederived magma (Heiken et al., 1974). The black glass is the devitrified or quench-crystallized equivalent of the orange glass.

Among elements determined by INAA, the orange glasses are distinguished compositionally from high-Ti mare basalt by high $\mathrm{Cr} / \mathrm{Sc}$ ratios, high $\mathrm{Co}$ and $7 . \mathrm{n}$ concentrations, and different $\mathrm{REE}$ concentrations and patterns (Korotev and Kremser, 1992; Table A5). On this basis, most of the regolith breccias found in samples 76503 and 76283 contain orange-glass as well as mare-basalt components (see $\mathrm{Zn}$ concentrations of regolith breccias, Table 3 ), and seven of the breccias consist almost entirely of orange and black pyroclastic debris. A few of the particles from samples 72443 and 72503 are also relatively rich in orange glass. Breccias consisting mainly of orange/black glass are rare among Apollo 17 rocks. One such "rock" occurs among the $4 \mathrm{~mm}-10 \mathrm{~mm}$ fraction of 72500

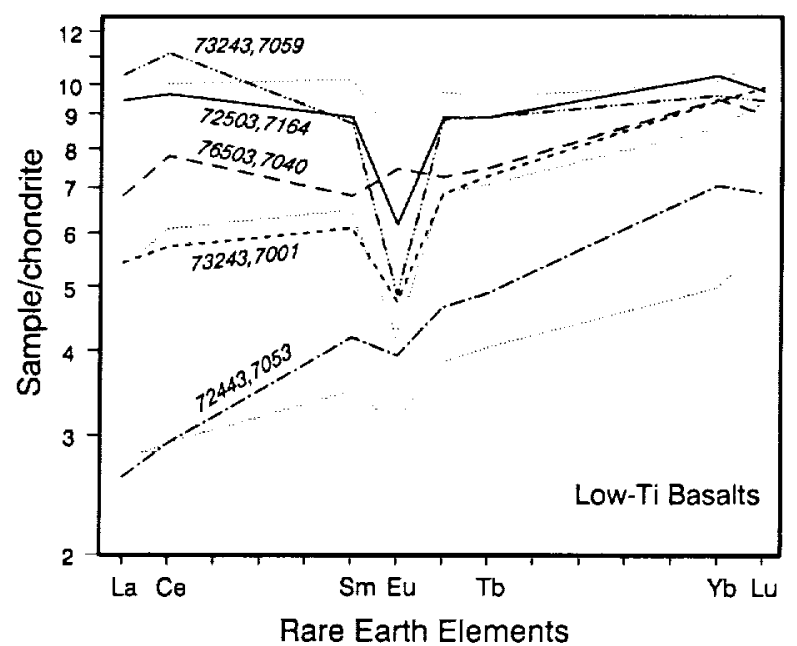

FIG. 14. Chondrite-nomalized REE patterns of lithic fragments tentatively identified as VLT basalt from samples 72443, 72503, 73243, and 76503 . For comparison, a few of the known Apollo 17 VLT basalts from the literature are shown by the dotted lines (Wentworth et al., 1979; Blanchard and Budahn, 1979).

(Jerde et al., 1987), and a larger orange-glass-rich breccia, 70175, was reported by Simon et al. (1990). Presumably, these samples have been delivered to the massif soils by small impacts on the valley floor where concentrations of pyroclastic glasses occur.

\section{Unusual or Unique $\mathbf{2} \mathbf{m m} \mathbf{- 4} \mathbf{m m}$ Lithic Fragments}

In addition to lithic fragments corresponding to the major lithologic groups at Apollo 17, we have found a variety of lithic fragments of unusual composition and lithology. Some of these are designated individually on Figs. 4-6, and REE patterns are shown in Fig. 15. These are described briefly below.

Metal-rich Fragments-Sample 72503,7052 consists of $79 \%$ Fe-Ni-Co metal and $21 \%$ lunar silicates of highland affinity (Table 5). The metal composition is similar to that found in I, chondrites but is depleted in $\mathrm{Au}$ and As, presumably through loss by volatilization. The metal forms an irregular mass $-1.0 \mathrm{~mm} \times 1.3$ $\mathrm{mm}$ in cross section, and it contains no silicate inclusions. Sample 73243,7022 , a breccia that is low in $\mathrm{CaO}(8.8 \%$ ) and ITEs (e.g., 2.4 $\mu \mathrm{g} / \mathrm{g} \mathrm{Sm})$ and rich in volatiles $\left(213 \mu \mathrm{g} / \mathrm{g} \mathrm{Zn}, 0.73 \% \mathrm{Na}_{2} \mathrm{O}\right)$, also contains metal, presumably derived from an ordinary chondrite $(7300 \mu \mathrm{g} / \mathrm{g} \mathrm{Ni}, 301 \mathrm{ng} / \mathrm{g} \mathrm{Ir}$, and $108 \mathrm{ng} / \mathrm{g} \mathrm{Au}$ ).

Alkali-rich Fragments-In addition to the fragment of alkali anorthosite mentioned previously, two breccias, 76283,7147 and 73243,7099, contain Eu-rich alkali-anorthositic clasts (Figs. 8, 15). Several of the lithic fragments consist of felsite $(76283,7024)$, monzogabbro $(72503,7208)$, and impact-melt breccias that have alkali-element enrichments, reflecting the presence of felsite, quartz monzodiorite, or monzogabbro clasts $(72443,7056 ; 72503,7169$; 76503,7025 ; Fig. 15). Sample 76503,7025 contains a clast of monzogabbro in addition to felsite clasts (Table A3d); the monzogabbro clast contains rare grains of monazite in addition to the more common lunar phosphates, whitlockite and apatite (Jolliff, 1993).

Feldspathic Melt Breccias-A substantial number of meltbreccia fragments are feldspathic $(\mathrm{FeO}<8 \%$ ) and have low ITE concentrations (e.g., $\mathrm{Sm}<10 \mu \mathrm{g} / \mathrm{g}$ ) relative to the prominent, compositionally tight cluster of melt breccias (Figs. 4-6). Although 
most of these feldspathic melt breccias have low ITE and FeO concentrations as a result of one or more large, feldspathic highland clasts, a few of these are not unusually clast rich $(e, g, 76503,7003$ and 72503,7102; Table A3d). Sample 72443,7046, a clast-free impact melt, has low ITE concentrations, a high $\mathrm{Sc} / \mathrm{Sm}$ ratio, and is enriched in $\mathrm{FeO}(\sim 12 \%$; Table A3d) compared to the Apollo 17 melt-breccia groups (Table 2) and those from other sites ( $c f$. Korotev, 1994).

Others-One lithic fragment from station 3, 73243, 7002, is compositionally similar to 72275-type KREEP basalt; it is the only fragment we have found that has this distinctive composition. Samples 76503,$7139 ; 76503,7175$; and 76503,7190 (Table A3d) are compositionally similar to the unusually magnesian and olivine-rich melt breccia 76055 (as summarized in Meyer, 1994). Sample 76503,7020 is an agglutinate that has relatively high REE and very high $\mathrm{Ta}, \mathrm{Th}$, and $\mathrm{U}$ concentrations, but very low alkali concentrations (Table A4), possibly as a result of volatilization. This unusual composition may have been the result of a clast of felsite (or specifically the mineral yttrobetafite); if so, our thin section of this agglutinate did not reveal it.

FIG. 15. Chondrite-normalized REE patterns of lithic fragments of unusual composition. (a) Unusual ITE-rich lithic fragments: 72503,7208 is a monzogabbro breccia, exceptionally enriched in REEs for an Apollo 17 sample; 73243,7002 is a lithic fragment of similar composition to KREEP basalt from sample 72275. 76283,7024 is a fragment of granitic composition $\left(-6 \mathrm{wt} \% \mathrm{~K}_{2} \mathrm{O}\right)$; and 76503,7020 is an agglutinate, enriched in high-field-strength elements. (b) Impact-melt breccias: 76503,7025 is alkali-rich and has clasts of felsite and monzogabbro; 72503,7169 is an alkalirich, fine-grained, "incipiently" poikilitic melt breccia; 72443,7056 is an alkalirich melt breccia $\left(-2.2 \% \mathrm{~K}_{2} \mathrm{O}, 3.3 \mu \mathrm{g} / \mathrm{g}\right.$ Cs); 76503,7003 is a clast-poor impactmelt breccia; and 72443,7046 is a coarsegrained fragment of clast-free impactmelt rock. The stippled pattern marks the range of REE patterns for members of the ITE-rich impact-melt breccia group, which are distinct from the aphanitic and poikilitic melt breccias, whose average REE patterns are plotted for comparison (see also Table 2). (c) ITE-poor lithic fragments: 76283,7119 is a fragment of alkali anorthosite and 76283,7147 and 73243,7099 are dark, alkali-anorthositic breccias that have high concentrations of $\mathrm{Na}_{2} \mathrm{O}$ and $\mathrm{Eu} ; 73243,7087$ and 72503,7041 are gabbroic breccias that have low concentrations of ITEs and siderophile elements; and 73243,7022 is a metal-rich breccia. 
TABLE 5. Composition of metal-rich particle 72503,7052, estimated compositions of metal and nonmetal phases, and comparison to metal in $\mathrm{L}$ chondrites.

\begin{tabular}{lccccc}
\hline & & \multicolumn{3}{c}{72503,7052} & $\begin{array}{c}\text { metal in } \mathrm{L} \\
\text { chondrite }\end{array}$ \\
\cline { 3 - 5 } & & particle & nonmetal & metal $^{1}$ & \\
\hline $\mathrm{Na}$ & $\%$ & 0.083 & 0.400 & & \\
$\mathrm{Ca}$ & $\%$ & 2.4 & 11.7 & & \\
$\mathrm{Sc}$ & $\mu \mathrm{g} / \mathrm{g}$ & 1.09 & 5.25 & & \\
$\mathrm{Cr}$ & $\mu \mathrm{g} / \mathrm{g}$ & 304 & 1460 & & \\
$\mathrm{Fe}$ & $\%$ & 66.5 & 2.94 & 83.2 & 84.5 \\
$\mathrm{Co}$ & $\%$ & 0.729 & 0.000735 & 0.92 & 0.70 \\
$\mathrm{Ni}$ & $\%$ & 12.6 & & 15.9 & 14.7 \\
$\mathrm{As}$ & $\mu \mathrm{g} / \mathrm{g}$ & 4.6 & & 5.8 & 18.7 \\
$\mathrm{La}$ & $\mu \mathrm{g} / \mathrm{g}$ & 0.49 & 2.4 & & \\
$\mathrm{Sm}$ & $\mu \mathrm{g} / \mathrm{g}$ & 0.192 & 0.92 & & \\
$\mathrm{Eu}$ & $\mu \mathrm{g} / \mathrm{g}$ & 0.38 & 1.83 & & \\
$\mathrm{Yb}$ & $\mu \mathrm{g} / \mathrm{g}$ & 0.15 & 0.72 & & \\
$\mathrm{Ir}$ & $\mu \mathrm{g} / \mathrm{g}$ & 3.63 & & 4.58 & 5.01 \\
$\mathrm{Au}$ & $\mu \mathrm{g} / \mathrm{g}$ & 0.60 & & 0.76 & 1.76 \\
mass & $\mathrm{mg}$ & 52.2 & 10.8 & 41.3 & \\
fraction & $\%$ & & 20.8 & 79.2 & \\
\hline & & & & \\
\hline
\end{tabular}

1 Calculated compositions assuming (1) the metal contains negligible $\mathrm{Sc}$ and other lithophile elements, the nonmetal contains negligible $\mathrm{Co}, \mathrm{Ni}, \mathrm{As}, \mathrm{Ir}$, and $\mathrm{Au},(2)$ the $\mathrm{Fe} / \mathrm{Sc}$ and $\mathrm{Co} / \mathrm{Sc}$ ratios of the nonmetal are 5600 and 1.4 , and (4) the sum of $\mathrm{Fe}, \mathrm{CO}$, and $\mathrm{Ni}$ in the metal is $100 \%$.

${ }^{2}$ Mean of eight L chondrites, Rambaldi (1976).

\section{Comparison of North-Massif and South-Massif Samples: Interstation Variation}

Several first-order differences exist between North-Massif, station-6 soils and the South-Massif, station-2 and station- 3 soils (e.g., Fig. 4a vs. Figs. 5a, 6a). In the station-6 soils, the three major Apollo 17 rock groups (noritic melt breccias, ITE-poor highland lithologies, and mare basalts) are represented subequally (Fig. 16). In addition to mare-basalt components, the station-6 samples contain several regolith breccias composed entirely of orange-glass debris; both of these components reflect material delivered to the lower massif slopes by craters of the central valley caused by Tycho secondary impactors from the south (Arvidson et al, 1976). In contrast, soils from station 2 have little contribution from the valley foor; the majority of lithic fragments are impact-melt breccias. The lithologic diversity at station 3 is only slightly greater than at station 2.

The compositions of the regolith breccias and agglutinates at each sampling station reflect these differences in the proportions of rock types. In the station- 6 samples, the compositional distribution of regolith breccias and agglutinates is between high-Ti mare basalt and an average highland composition, as well as intermediate to the ITE-rich impact-melt breccias and the ITE-poor lithologies (e.g., Fig. 4a). In the samples from stations 2 and 3, regolith-breccias contain far less mare material and are enriched in impact-melt components relative to those of station 6 . Despite the fact that the $<1 \mathrm{~mm}$ soil fines from both station-2 samples, 72441 and 72501 , are mature and those corresponding to the station-6 samples are submature, the station- 6 samples have a higher proportion of regolith breccias and agglutinates in the $2 \mathrm{~mm}-4 \mathrm{~mm}$ size range. This suggests a decoupling of the $2 \mathrm{~mm}-4 \mathrm{~mm}$ particles and the $<1$ $\mathrm{mm}$ fines of the station-2 samples.
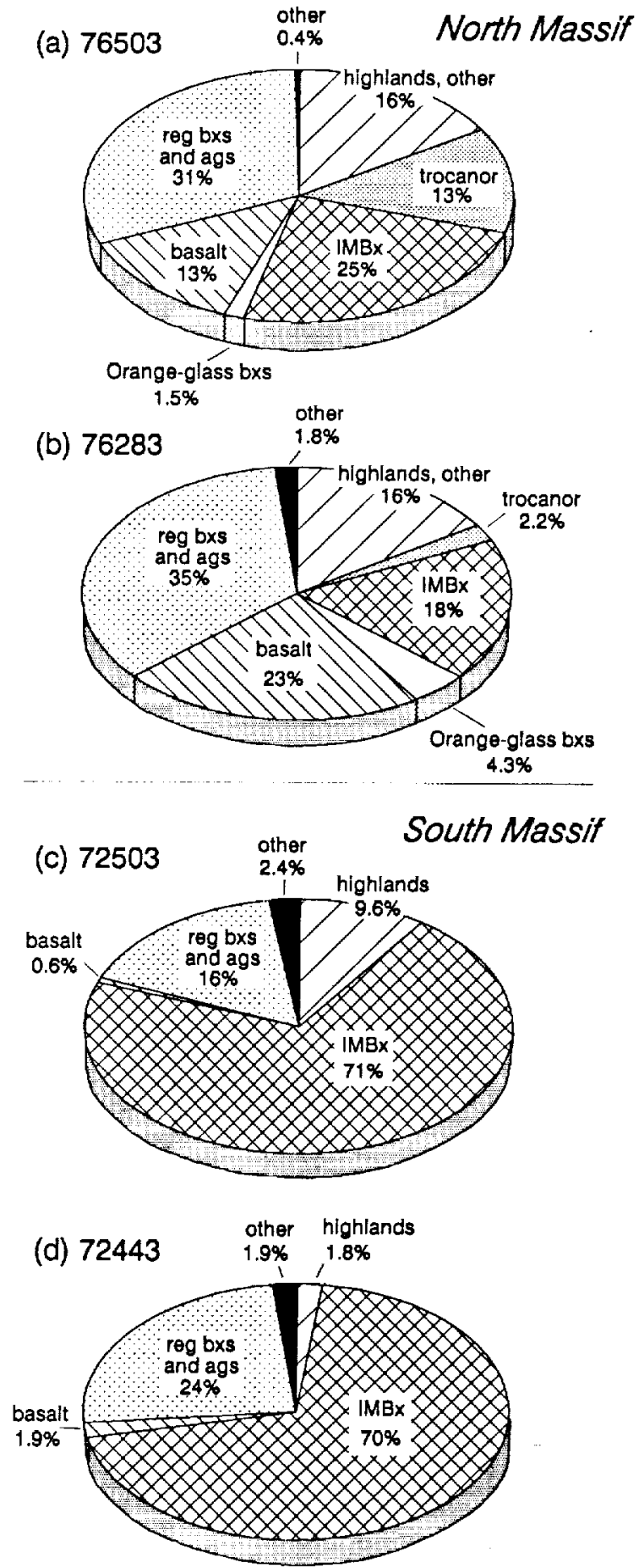

FIG. 16. Mass-weighted proportions of major lithologies in (a) 76503, (b) 76283, (c) 72503, and (d) 72443. "Highlands" refers to ITF-poor highland particles other than troctolitic anorthosite. Abbreviations: trocanor $=$ troctolitic anorthosite, IMBx = impact-melt breccias (all varicties), basalt = high-Ti mare basalt, reg bxs and ags = regolith breccias and agglutinates The proportion of IMBx in 76283 includes a small group of lithic fragments identified optically as melt breccias but not analyzed by INAA for this work. "Other" includes VLT basalts and those lithic fragments listed as "others" in Figs. 4-6. Note the similar distributions within the two station-6 samples and within the two station-2 samples. 
Differences between samples from the two massifs are also evident from comparison of groups of the same rock types (Tables $3,4)$. For example, among the impact-melt breccias, there are slight but significant differences in the compositions of the poikilitic samples from North-Massif and South-Massif soils. Those samples from station 6 typically have lower $\mathrm{Al}_{2} \mathrm{O}_{3}, \mathrm{Sc}, \mathrm{Cr}$, and $\mathrm{Ni}$ and higher $\mathrm{Na}_{2} \mathrm{O}, \mathrm{Sr}$, and Eu concentrations (Tables 3,4 ). These compositional differences between the poikilitic groups from the two massifs, noted in the "Results" section above, suggest broad-scale differences in the basin melt ejecta that may reflect gross lateral differences in basin target rocks. This was not previously recognized in studies of the large breccias, although Ryder and Stockstill (1995) now report similar compositional differences among splits of larger breccia samples.

Considering only the lithic fragments that we classify as impactmelt breccias, the South-Massif samples (combining 72503 and 72443) have about the same percentage (by mass) of poikiliticgroup breccias $(65 \%)$ as North-Massif sample $76503(64 \%)$. Their percentages of ITE-rich breccias are also similar $(7.6 \%$ and $5.4 \%$ respectively). They differ in their percentages of aphanitic-group breccias $(12 \%$ vs. $1.3 \%)$ and in ITE-poor $(\mathrm{Sm}<12 \mu \mathrm{g} / \mathrm{g})$ or clastrich melt breccias ( $15 \%$ vs. $29 \%$ ).

The distributions of ITE-poor highland lithologies differ significantly between samples from the two massifs. In addition to a more diverse group of granulitic breccias, station-6 samples contain fragments of coarse-grained, magnesian, troctolitic anorthosite, which are absent in the station-2 samples.

The ratio of melt breccias to ITE-poor highland lithologies also differs between samples from the two massifs. The ratio of melt breccias to ITE-poor highland lithologies in the station-6 samples is $\sim 1: 1$. In the station-2 samples, however, the ratio is $\sim 5: 1$ (72501) or grcater (72443). These differences are consistent with a crudely laycred model for the massifs (see Fig. 2), as suggested by Rhodes et al. (1974), and reflect the local geology. The soils from stations 2 and 3 are part of the "light mantle," which is thought to contain material derived from near the top of South Massif by a surge of material down the slopes following a secondary impact from Tycho (Arvidson et al., 1976; Wolfe et al., 1981; Luchitta, 1992). The abundance of impact-melt breccias in the South-Massif samples suggests that there is a "layer" rich in impact-melt ejecta atop the massifs. This is consistent with observations made by the astronauts of boulder tracks and outcrops or concentrations of boulders, indicating that the boulders came mainly from higher elevations on the massifs (Wolfe et al., 1981). The apparent decoupling of 2 $\mathrm{mm}-4 \mathrm{~mm}$ particles from the $<\mathrm{I} \mathrm{mm}$ fines at station 2, mentioned in a previous section, may be related to the mechanism of the lightmantle deposit. Perhaps fines associated with the surge dropped out close to the point of impact and the fines now associated with the light mantle were incorporated nearer the base of the massif.

The ITE-poor highland lithologies presumably predate the basin impact that produced the melt breccias that are more prominent higher in the massifs. We suggest that the ITE-poor materials constitute a greater proportion in the lower parts of the massifs (as also inferred by Wolfe et al., 1981). We do not know whether these materials were in place in the present massif structures prior to the basin-forming event or were emplaced during the basin-forming event as part of a very large ejecta package containing both fragmental debris and impact melt. We suggest, however, that the ITE-poor highland materials found in station-6, North-Massif soil, which are similar to clasts found in the poikilitic breccia boulders, may be part of the pre-Serenitatis upper crust in this region. The correspondence between the mean composition of the ITE-poor highland lithic fragments and the extrapolation of the clast-dilution trend of the poikilitic melt breccias supports this interpretation of massif stratigraphy.

\section{Intrastation Variations}

The lithologic distribution differs among samples from a given station (Fig. 16), although, in general, interstation variations in lithologic distributions exceed intrastation variations. This is seen in the relative percentages of rock types shown in Fig. 16. Although 76503 and 76283 differ in proportions of rock types, they are more similar to each other than to either of the station-2 samples in their proportions of rock types and in the compositions of similar rock types (Table 3 ).

As an example of intrastation variation, at station 2, sample 72503 has fewer regolith breccias and a higher proportion of ITEpoor highland material than sample 72443. Although our split of 72443 was only $2 \mathrm{~g}$ ( 85 particles) compared to $5 \mathrm{~g}$ for 72503 and thus, perhaps, less representative than 72503 , the differences between them are too substantial to attribute entirely to sampling statistics. The difference in highland components may be related to the sample locations. Sample 72503 was taken $5 \mathrm{~m}$ from the nearest melt-breccia boulder, whercas sample 72443 was collected from beneath a boulder that was overturned by the astronauts. Fragmentation of this boulder during emplaccment may have contributed to the high proportion of melt breccia in 72443 . The lower proportion of regolith breccias in 72503 compared to 72443 remains puzzling.

At station 6, sample 76283 has a smaller proportion of highland lithic fragments but more mare basalt than 76503 (Fig. I6) as indicated also by compositions of the soil fines. Sample 76281 is enriched in Fe and Sc, elements that are concentrated in basalts, relative to other station-6 soil fines (Korotev and Kremser, 1992). There may be several reasons for variations in the distribution of rock types at station 6 . First, highland material was delivered to station 6 by mass wasting of the massif and mare material by impact ejecta thrown up from the valley floor. It is unlikely that the processes of mass wasting and cratering have produced uniform distributions of materials on such a small scale (76283 and 76503 were collected $25 \mathrm{~m}$ apart). Second, 76283 and 76503 are from different soil depths; 76283 was taken from $2 \mathrm{~cm}-5 \mathrm{~cm}$ depth, whereas 76503, although scooped from the top of the regolith, was collected on the rim of a small crater (Wolfe et al., 1981), so it probably represents subsurface regolith, which is consistent with its submature $\mathrm{I}_{S} / \mathrm{FeO}$.

We might also expect the distribution of boulders and rocks to affect local regolith variability. Korotev and Kremser (1992) noted that surface soils taken near the boulders at station 6 have the highest ITE concentrations, presumably due to a higher proportion of melt-breccia fragments "eroded" from the boulders. Ilowever, despite the fact that 76280 was taken only $1 \mathrm{~m}$ from a melt-breccia boulder, the fine fraction is not relatively enriched in ITEs and the coarse fraction is not enriched in melt-breccia fragments (Fig. 16). On the other hand, local fragmentation of a large rock may have caused the high proportion of troctolitic anorthosite in 76503 relative to 76283 . Troctolite samples 76535 and 76536 (found in a rake sample from the same soil as 76503 ), related troctolitic anorthosite 76335 (Warren and Wasson, 1978), and rocklets from 76500 (Warren et al, 1987) may result from the breakdown of the same rock. 


\section{Comparison of Lithic Fragments with Large-rock Samples: Distribution and Diversity of Lithologies}

The proportions of rock types as determined from unbiased sets of $2 \mathrm{~mm}-4 \mathrm{~mm}$ lithic fragments differ from the proportions of rock types as indicated by large-rock samples (e.g., >5g). Ryder (1992a) reached a similar conclusion by comparing soil and melt-breccia compositions. Consider station 6 . From a compilation of literature data on the large-rock samples (mainly Meyer, 1994), the majority $(-90 \%$, by mass) of large rocks at station 6 are melt breccias. Troctolite and troctolitic-anorthosite $(\sim 5 \%)$ and norite $(\sim 3 \%)$ are the only other rock types present in excess of $1 \%$. The $2 \mathrm{~mm}-4 \mathrm{~mm}$ population, on the other hand, comprises subequal amounts of four rock types: impact-melt breccia, ITE-poor highland lithologies (granulitic breccias and troctolitic anorthosite), mare basalt, and regolith breccias. We consider the proportions of rock types as determined from lithic fragments in the soil to be more representative of the local rock types for the following reasons: (1) There are many more $2 \mathrm{~mm}-4 \mathrm{~mm}$ fragments than large-rock samples in the collection. For example, only 34 large-rock samples were returned from station 6 , whereas in one $5 \mathrm{~g}$ split of 76503, there are over 200 lithic fragments. (2) The $2 \mathrm{~mm}-4 \mathrm{~mm}$ fragments have no selection bias; for this study, all fragments in one $5 \mathrm{~g}$ split were analyzed. At the North and South Massifs, the astronauts targeted large, coherent boulders for sampling; consequently, most of the rocks returned were impact-melt breccias. (3) As a result of the efficiency of small-scale lateral mixing, samples of soil typically contain a good representation of local rock types; thus, they provide information on the local distribution of rock types. Such information is difficult to obtain from the large-rock data. On the other hand, we recognize that just as the large-rock distribution may be biased toward melt breccia because such rocks are extremely cohcrent and resistant to comminution, the smaller lithic fragments may be biased towards the less coherent highland lithologies.

Nonetheless, the diversity of lithologies found among the 2 mm-4 mm fragments compares well with the diversity found among the large-rock samples. In fact, the range of compositions of lithic fragments from the two North-Massif soil samples nearly equals the range of compositions of the entire Apollo 17 large-rock suite. Almost all the major compositional types of basalt are found among the $2 \mathrm{~mm}-4 \mathrm{~mm}$ lithic fragments at station 6 . The $2 \mathrm{~mm}-4 \mathrm{~mm}$ lithic fragments from station 6 also show a wide range of regolith compositions, including the group that consists almost entirely of orange and black glass breccias and the previously unrecognized regolith-breccia group that we infer, from lack of Serenitatis-related mare or impact-melt components, to represent pre-Serenitatis surface materials. Station- 2 soils have a more limited range of rock types, but the compositional diversity of $2 \mathrm{~mm}-4 \mathrm{~mm}$ impact-melt breccia fragments exceeds that of the melt breccias from larger samples. In particular, the $2 \mathrm{~mm}-4 \mathrm{~mm}$ lithic fragments from station 2 contain the group of ITE-rich impact-melt breccias that is compositionally distinct from the aphanitic and poikilitic meltbreccia groups. Impact-melt breccias of the $2 \mathrm{~mm}-4 \mathrm{~mm}$ fragments from station 6 are dominantly of the poikilitic group, but we have found several fragments of aphanitic melt breccias, a type not found previously in station- 6 samples.

The $2 \mathrm{~mm}-4 \mathrm{~mm}$ ITE-poor highland lithic fragments include a diverse and abundant group of granulitic breccias ranging from noritic to gabbro-noritic bulk compositions but only a small proportion of igneous fragments. The igneous rock types, known mainly from studies of clasts in large breccias, are relatively uncommon among the $2 \mathrm{~mm}-4 \mathrm{~mm}$ fragments. Station-6 samples contain $2 \mathrm{~mm}-4 \mathrm{~mm}$ fragments of coarse-grained troctolitic anorthosite but none of norite, which is surprising given that norite is a common melt-breccia clast lithology. These differences in proportions of lithologies between the highland components of the soil and clast populations of the breccias are consistent with the interpretation that the ITE-poor highland components in the soil were not produced solely by the breakdown of the melt-breccia boulders.

In general, rock types that are rare among large samples, such as spinel troctolite, dunite, ferroan anorthosite, felsite, VLT basalt, and KREEP basalt, are also rare or absent among the $2 \mathrm{~mm}-4 \mathrm{~mm}$ fragments. We have found no individual lithic fragments composed entirely of dunite or spinel troctolite; however, based on compositions (mainly $\mathrm{Cr}$ concentrations), these lithologies do occur as clasts in some of the $2 \mathrm{~mm}-4 \mathrm{~mm}$ breccias. Their occurrence mainly as clasts in boulder breccias is consistent with their being mid- to lower-crustal components, sampled only by basin impacts that formed the poikilitic boulder breccia. This does not preclude their occurrence among soil particles (e.g., as found among $1 \mathrm{~mm}-2$ $\mathrm{mm}$ particles by Bence et al., 1974 and Blanchard et al., 1975).

Lithic fragments that appear compositionally to be ferroan anorthosite are found in four of the five samples and are more common than expected based upon their dearth among larger samples. The observation that these are not found as large rocks may result from limited sampling or it may indicate that only finely pulverized remnants of ferroan anorthosite remain in the Apollo 17 region. The compositional range, as indicated by the spread of Eu concentrations (Figs. 8, 9) is consistent with their being of diverse and possibly exotic origin.

Very-low-Ti basalts, basaltic glasses, and lithic fragments are an important component of the basalts in the Taurus-Littrow valley (Lindstrom et al., 1994) and may be prominent elsewhere in the Serenitatis region, yet none have been found among the large samples from Apollo 17. The few samples that have been found are small and are lithologically and compositionally diverse (e.g., Lindstrom et al., 1994, and references therein). The five lithic fragments of VLT basalts that we have found are also texturally and compositionally diverse (Fig. 14). That several of these occur as lithified breccias suggests derivation from impacts distant from the Apollo 17 site where there is a substrate rich in VLT basalt. That they were found in samples from all three stations involved in this study as well as at other stations (Lindstrom et al., 1994) indicates that, although minor, they are a widespread component at the Apollo 17 site and that they may have affinity with the highland materials.

\section{Relationships between $2 \mathrm{~mm}-4 \mathrm{~mm}$ particles and $<1 \mathrm{~mm}$ Fines}

Based on data primarily for major elements, Rhodes et al. (1974) noted that most of the compositional variation in Apollo 17 soils ( $<1 \mathrm{~mm}$ fines) could be explained by variation in abundance of four components: mare basalt, orange glass, ITE-rich noritic impact-melt breccia, and an ITE-poor, feldspathic component ("anorthositic gabbro"). Including data for a number of trace elements, Korotev and Kremser (1992) (who used an anorthositicnorite composition as the ITE-poor feldspathic component) argued that other components were also needed to account for the mass balance. They showed that the basaltic component of the soils from the valley floor contained less $\mathrm{Ti}$ than high- $\mathrm{Ti}$ mare basalt and argued that VLT basalt was probably also a significant component 
of the regolith ( $7 \%$ of the total basalt component). They also noted that the North-Massif soils, in particular those from station 6, required a high-Mg' component ("MG"), which they modeled as magnesian troctolite/norite. In detail, station-2 soils were not fit well by the model, which is a surprising result considering that the station-2 soils contain only minimal quantities of mare basalt and orange glass. Inclusion of a component of "Apollo 17 KREEPbasalt" with the composition of ITE-rich "pigeonite basalt" from station-2 sample 72275 (Salpas et al., 1987) improved the fit but required $\sim 4 \%$ of such a component in the best-fit mixture at station 2. Mass-balance models, such as those of Rhodes et al. (1974) and Korotev and Kremser (1992), cannot provide unique solutions because they are based on assumptions about which of the observed rock types are the significant components of the regolith, but they do indicate reliably when a particular set of assumed components does not account for the composition of the soil

From our investigation of the $2 \mathrm{~mm}-4 \mathrm{~mm}$ fragments, we have identified lithologies actually present in the soils, and assuming that they are not significantly different from the lithologic components that make up the bulk of the $<1 \mathrm{~mm}$ soil, we can now correlate these lithologies with the model results of Korotev and Kremser. The dominant ITE-poor highland lithologies in samples 76283 and 76503 are granulitic breccias and magnesian troctolitic anorthosite, the latter almost certainly related to the larger samples of troctolite 76535 and troctolitic anorthosite 76335. Mineral compositions in the granulitic breccias range from magnesian to ferroan, and bulk compositions range from those of noritic anorthosite to anorthositic norite, with $\sim 22-26 \mathrm{wt} \% \mathrm{Al}_{2} \mathrm{O}_{3}$. When averaged, these compositions correspond to an anorthositic-norite component similar in composition to the component used by Korotev and Kremser, who recognized that granulitic breccias are the main ITE-poor, feldspathic rock types at the site. In detail, the ferroan granulitic breccias, $\mathrm{Mg}^{\prime} \approx 0.67$, correspond to the anorthositic gabbro component of Rhodes et al. (1974), $\mathrm{Mg}^{\prime} \approx 0.68$. The magnesian granulitic breccias are more magnesian on average $\left(\mathrm{Mg}^{\prime} \approx 0.72-0.79\right)$ than the anorthositic-norite component of Korotev and Kremser $\left(\mathrm{Mg}^{\prime} \approx\right.$ $0.70)$. Although we have found a highly magnesian component in the troctolitic anorthosites of 76283 and $76503\left(\mathrm{Mg}^{\prime} \approx 0.86\right)$ as predicted by Korotev and Kremser, it is less mafic $(-6 \% \mathrm{MgO})$ than their "MG" component $(16.8 \% \mathrm{MgO})$ or troctolite $76535(19 \%$ $\mathrm{MgO}$; Rhodes et al, 1974). Unless olivine and orthopyroxene from this coarse-grained lithology break down preferentially relative to plagioclase into $<1 \mathrm{~mm}$ grain sizes, it is the combination of troctolitic anorthosite and magnesian granulitic breccia (up to $13 \%$ $\mathrm{MgO}$ ) that satisfies the requirement for a highly magnesian component in the $<1 \mathrm{~mm}$ soil. As noted by Korotev and Kremser, if the actual carrier of the excess $\mathrm{Mg}$ in the North-Massif soils is, as we now believe, less mafic than the "MG" component used in their model, then mass balance requires that the abundance of the component in the soil be greater than that predicted for the "MG" component by their model.

In $<1 \mathrm{~mm}$ soils from station 2, the ITE-poor highland material is relatively well satisfied by a single mixing component, anorthositic norite (Korotev and Kremser, 1992). This is consistent with the absence of the troctolitic-anorthosite lithology in samples 72443 and 72503 (Figs. 4, 5). However, in the models of both Korotev and Kremser (1992) and Rhodes ef al. (1974), the ITE-poor highland component constitutes $\sim 45 \%$ of the $<1 \mathrm{~mm}$ soil. We find that only $\sim 10 \%$ of the $2 \mathrm{~mm}-4 \mathrm{~mm}$ particles are anorthositic norite in composition (recalculated on a regolith-breccia-free basis),

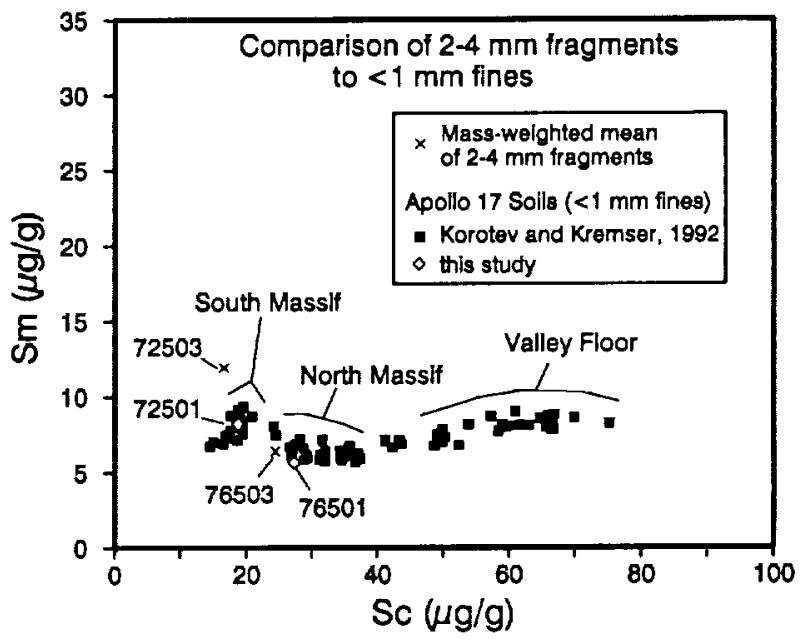

FIG. 17. Concentrations of Sc vs. Sm of mass-weighted mean compositions of $2 \mathrm{~mm}-4 \mathrm{~mm}$ particles from samples 72503 and 76503 compared to those of the $<1 \mathrm{~mm}$ soil samples from all Apollo 17 locations. The $<1 \mathrm{~mm}$ soil compositions are from Korotev and Kremser (1992).

and those are mostly granulitic breccias. This is reflected in the difference between the mass-weighted mean composition of the 2 $\mathrm{mm}-4 \mathrm{~mm}$ fragments and that of the corresponding $<1 \mathrm{~mm}$ soil (Fig. 17). For example, the 72503 mean composition is substantially richer in ITEs (e.g., $\mathrm{Sm}=11.8 \mu \mathrm{g} / \mathrm{g}$ ) than the 72501 bulk composition $(8.2 \mu \mathrm{g} / \mathrm{g})$. Thus, the South-Massif $<1 \mathrm{~mm}$ soils have a higher proportion of ITE-poor highland components and less impact-melt breccia than the corresponding $2 \mathrm{~mm}-4 \mathrm{~mm}$ lithic fragments. There are two possibilities that are not mutually exclusive: (1) the ITE-poor material is more friable and thus breaks down more readily and concentrates in the finer fractions of the soil; and (2) at least part of the fine soil is derived from a different part of South Massif than the coarse material. The latter possibility is consistent with the earlier observation that, based on soil maturity and number of agglutinates in 72503 , the $<1 \mathrm{~mm}$ fines and coarse particles are "decoupled." The latter possibility is also consistent with the mode of origin of the light mantle. Lucchitta (1992) proposed that the light mantle is an "impact-propelled feature" and not an avalanche, although Wolfe et al. (1981) suggested that in the process of dislodging material from the top of the massif, material was also mobilized in an avalanche fashion. Perhaps much of the coarse material was launched from the top of the massif, whereas the $<1 \mathrm{~mm}$ soil was "swept up" from South-Massif slopes during formation of the light-mantle deposit. If the subsurface rocks of North and South Massif are fundamentally similar, then the differences in the ratios of their noritic-breccia to ITE-poor components and differences in proportions of their ITE-poor highland components may reflect stratigraphic differences. The North-Massif soils reflect the makeup of lower levels of the massifs, the light-mantle fine soils at South Massif reflect intermediate levels, and the coarser, impact-melt-breccia-rich components of the light mantle reflect upper levels.

Another difference between the station- 6 and station- 2 soils noted by Korotev and Kremser (1992) was an apparent difference in ITE-bearing components. A component with the composition of Apollo 17 KREEP basalt (as in 72275 ) provided an improved model fit of components to the average station-2 soil. However, we have 
found only one lithic fragment that is compositionally similar to 72275 KREEP basalt. Instead, we now consider as an ITE-bearing component the group of ITF-rich impact-melt breccias, which is not common among the large-rock samples, and whose average composition is an alternative to (and quite different from) the 72275-like component. Using the average composition of the ITErich melt-breccia group (Table 2) as a component instead of the KRFFP basalt component of Korotev and Kremser (1992) provides a better fit to the composition of the $<1 \mathrm{~mm}$ fines from station 2 . Thus, overall, our knowledge of compositions of $2 \mathrm{~mm}-4 \mathrm{~mm}$ soil particles significantly improves our understanding of the compositions of the $<1 \mathrm{~mm}$ fines and refines our knowledge of the geology of the Taurus-Littrow site.

\section{Implications for Remote-Sensing Studies and Future Robotic Missions to the Moon}

Recent remote-sensing studies (e.g., Pieters and Taylor, 1989; Ilawke et al., 1992) have focused on relatively small areas (e.g., I $\mathrm{km}$ "footprint") and spectral reflectance data have been used to characterize regions of the lunar highlands as anorthositic (>90\% plagioclase), noritic or gabbroic (low- or high-Ca pyroxene-rich, respectively), troctolitic (olivine-bearing), or some mixture of these. Such average characterizations, however, are for areas that may be large relative to individual, subsurface geologic rock formations. Information pertaining to important details of composition and petrologic history are lacking. For example, (1) are the rocks of ferroan, magnesian, or alkaline geochemical character, (2) what is the range of rock types, (3) are the surface units composed of breccias, impact-melt rocks, volcanic rocks, plutonic rocks, or are they soils, and (4) do any of the rocks at the site form related rock serics? Analyses of fresh rock surfaces such as central peak slopes or crater walls may yield information on bedrock, but the makeup of regions bearing a veneer of regolith is obscured and, at best, averaged by remote-sensing techniques. Near-infrared reflectance spectra of North and South Massifs and other similar-appearing locations on the rim of the Serenitatis basin indicate that the mineralogical makeup of the rocks is generally that of anorthositic norite (llawke et al., 1992). Indeed, the average composition of a mixture of "noritic" impact melt breccia, relatively anorthositic granulitic breccias, and a variety of igneous rocks, including dunite, norite, and gabbro, is that of anorthositic norite. There are, however, no fragments of pristine anorthositic norite among the 2 $\mathrm{mm}-4 \mathrm{~mm}$ particles analyzed in this study, and there are few largerock specimens of true anorthositic noritc (e.g., $78255=48 \mathrm{~g}$; Warren and Wasson, 1978; I.SPET, 1973). It is difficult to infer the subregolith or sub-megaregolith basement geology from the average remotely-sensed surface composition. Data from specific rock samples are required.

Small lithic fragments in soils would be good targets for analysis in situ by either an immobile robotic lander or a mobile robotic rover. I ithic fragments could be easily separated from fine material by simple mechanical sicving on a grid, with the fines collected for chemical analysis. The lithic fragments could be sorted according to optical criteria by remote telcoperation using a color camera, much the same as we do in the laboratory prior to chemical analysis (see also Ryder et al, 1988, for effectiveness of optical discrimination of lithologic groups). A subset of samples representing the lithologic groups could then be analyzed for chemical and mineralogical components using techniques such as $\alpha x$-p-X, Raman, Mössbauer spectroscopy, or x-ray fluorescence.
Optical classification of a large number of lithic fragments, coupled with more detailed analysis of a subset, would provide a statistical distribution of rock types at a given sample site. This approach, combined with careful placement of a robotic sampler, would provide access to otherwise inaccessible samples such as steep rock ledges in crater walls, central peaks, deep rilles, or tall highland massifs like those bounding the Taurus-Littrow Valley. This approach would be especially useful for a single-point lander without mobility.

\section{SUMMARY AND RAMIFICATIONS FOR FUTURE EXPLORATION STRATEGIES}

Future lunar remote sensing and future near-term sampling and analysis will be dominantly of regolith materials. Resources will come from the regolith or will be the regolith itself. It is necessary to understand the regolith and how to obtain the most information from it. This study of highland massif samples from Apollo 17, like that of Ryder et al. (1988) of Apennine Front samples from $A$ pollo 15, demonstrates the wealth of information that can be derived from small lithic fragments contained in the regolith. If the only samples we had of the Apollo 17 site were $2 \mathrm{~mm}-4 \mathrm{~mm}$ particles, we would still know the composition and distribution of the major $A$ pollo 17 rock types. Specifically, we would know (1) that the massifs consist of several compositionally distinct groups of noritic impact-melt breccias with moderate ITE concentrations and ITE-poor highland lithologies that are dominantly granulitic breccias; (2) ferroananorthositic-suite rocks are rare but not absent; (3) high-Ti basalts underlie the valley floor and at least several compositionally distinct flows were exhumed by cratering; (4) Ti-rich pyroclastic glass is also a prominent mare component, whereas VLT basalt is rare and diverse; and (5) the light mantle has experienced little admixture of valley-floor material. We have also gained new understanding of the Apollo 17 site by studying $2 \mathrm{~mm}-4 \mathrm{~mm}$ particles. By analyzing numerous lithic fragments from the North- and South-Massif soil samples, we have (1) determined the distribution and proportions of the major rock types, (2) demonstrated subtle compositional variability within groups of related rocks, and (3) discovered lithologies that, because of sampling limitations, were not found as large rocks or as clasts with the large breccias.

The major rock types represented by the soil particles are mainly the same as those found among the large-rock samples, but because the soil samples include a large number of lithic fragments and are not biased by preferential sampling, they give a better estimate of the proportions of rock types represented by the most abundant material at the surface, which is regolith. Each soil sample gives an estimate of only the local (a sampling station) proportion of rock types, but by analyzing several soils at various locations, we can infer proportions and distribution of rock types throughout the Taurus-Littrow Valley (see also Korotev et al., 1995b). For example, we infer that VLT basalt and ferroan material occur in small proportions throughout the Taurus-Littrow Valley, and we infer that the ITE-rich melt-breccia group, found mostly as small lithic fragments, constitute a significant ITE-rich component, whereas KREEP basalt does not. Several igneous rock types found as larger rocks or clasts in large breccias, including norite, spinel troctolite, and dunite, were not found as pristine samples among the $2 \mathrm{~mm}-4 \mathrm{~mm}$ lithic fragments.

We have found significant differences between populations of lithologies from North- and South-Massif samples. Station-6 
samples contain a greater variety and proportion of ITE-poor highland rock types, while samples from stations 2 and 3 contain a greater varicty and proportion of ITE-rich highland material. Given that the station- 6 soils derive from a different level of the massif than those from stations 2 and 3 (i.e., the light mantle at the basc of South Massif derived mainly from an upper level, and the soil at the base of North Massif represents a greater vertical extent of the massifs and especially the lower levels), such differences in proportions suggest that impact-melt breccia is concentrated at the top of the South Massif.

The North- and South-Massif poikilitic melt breccias are slightly different in composition, which implies that the basin melt from which the poikilitic fragments derived, presumably Serenitatis, was not completely homogeneous. Compositional variability within the poikilitic melt-breccia group was not apparent in the data set of large rocks nor from mixing models involving the soils. The present study illustrates the advantage of analyzing a large number of particles by a consistent and precise technique.

We have found scveral rock types that are absent or poorly represented among the larger rock samples. For example, we have found a distinct group of impact-melt breccias that was previously unrecognized as a group at Apollo 17 and that is similar in lithophile-element composition to Apollo 15 group B. We have also discovered a group of regolith breccias that appears to predate the mare fill of the Taurus-Littrow Valley and perhaps also predates the presumably Serenitatis origin of the poikilitic impact-melt breccias. We have also found a variety of particles of unusual composition, such as a very-high-K-VLT basaltic breccia, unaltered, crystalline VLT-basalt fragments, unusually ITE-rich lithic fragments (some with alkali-element enrichments), and a metal-rich particle (possibly from an L-chondrite).

Given the great diversity of lithologic information contained in soil particles and that most information bearing on petrographic relationships is maintained, $2 \mathrm{~mm}-4 \mathrm{~mm}$ particles have the potential to provide detailed information about site geology. Compositional and petrographic information obtained on $2 \mathrm{~mm}-4 \mathrm{~mm}$ particles also serve to relate the soil and large-rock data sets. By examining the $2 \mathrm{~mm}-4 \mathrm{~mm}$ fraction, we can gain a better understanding of regolith formation and how large rocks relate to the regolith and local geology. Soils and the coarse lithic fragments they contain should be considered essential targets for future automated sample analysis and sample return missions.

Acknowledgments-Funding for this work has been provided by NASA Grant NAGW-3343 to L. A. Jlaskin. Reviews by Graham Ryder and Dave Lindstrom improved the manuscript and are appreciated.

Editorial handling: S. R. Taylor

\section{REFERENCES}

ANDERS E. and GREvesSE N. (1989) Abundances of the elements: Meteoritic and solar. Geochim. Cosmochim. Acta 53, 197-214.

Arvidson R., Drozd R., Guinness E., Hohenburg C., Morgan C., MORRISON R. AND OBERBECK V. (1976) Cosmic ray exposure ages of Apollo 17 samples and the age of Tycho. Proc. Lunar Sci. Conf. 7th, $2817-2832$

Bence A. E., Delano J. W., Papike J. J. and Cameron K. L. (1974) Petrology of the highlands massifs at Taurus-Littrow: An analysis of the 2-4 mm soil fraction. Proc. Lunar Sci. Conf. 5th, 785-827

BLANCIIARD D. P. AND BUDAHN J. R. (1979) Remnants from the ancient lunar crust: Clasts from consortium breccia 73255. Proc. Lunar Sci. Conf. 10th, 803-816.

Blanchard D. P., Korotev R. L., Brannon J. C., Jacobs J. W., Haskin L. A., Reid A. M., DONALdson C. H. AND BROWN R. W. (1975) A geochemical and petrographic study of 1-2 mm fines from Apollo 17 Proc. Lunar Sci. Conf 6th, 2321-2341.
Blanchard D. P., Jacobs J. W. and BranNon J. C. (1977) Chemistry of ANT-suite and felsite clasts from consortium breccia 73215 and of gabbroic anorthosite 79215. Proc. Lunar Sci. Conf. 8th, 2507-2524.

BrowN R. W. (1977) A sample fusion technique for whole rock analysis with the electron microprobe. Geochim. Cosmochim. Acta 41, 435438

Cadogan P. II. And TuRner G. (1976) The chronology of the Apollo 17 Station 6 boulder. Proc. Lunar Sci. Conf. 7th, 2267-2285.

DYMEK R. F., AlbeE $\Lambda$. L. AND CHodos A. A. (1975) Comparative petrology of lunar cumulate rocks of possible primary origin: Dunite 72415, troctolite 76535, norite 78235, and anorthosite 62237. Proc. Lunar Sci. Conf. 6th, 301-34 I.

Dymek R. F., AlBEe A. L. AND Chiodos A. A. (1976) Petrology and origin of Boulders $\# 2$ and $\# 3$, Apollo 17 Station 2. Proc. Lunar Sci. Conf. 7th, 2335-2378.

IJASKIN L. A. AND KOROTEV R. L. (1977) Test of a model for trace element partitioning during closed-system solidification of a silicate liquid. Geochim. Cosmochim. Acta 41, 921-939.

Haskin L. A., ShiH C.-Y., Bansal B. M., Rhodes J. M., Wiesmann H. AND NYQUIST L. E. (1974) Chemical evidence for the origin of 76535 as a cumulate. Proc. Lunar $S_{c i}$. Conf. 5th, 1213-1225.

HASKIN L. A., LiNDSTROM M. M., SAlPAS P. A AND LiNDSTROM D. J. (1981) On compositional variations among lunar anorthosites. Proc. Lunar Planet. Sci. Conf 12thB, 41-66.

hawke B. R., Peterson C. A, Lucey P. G., Blewett D. T., Bill J. F. III AND SPUDIS P. D. (1992) A spectral survey of the Serenitatis basin region of the Moon. In Workshop on Geology of the Apollo 17 Landing Site (eds. G. Ryder, H. H. Schmitt and P. D. Spudis), pp. 14-15. I.PI Tech. Rpt. 92-09. Lunar and Planetary Institute, Houston, Texas.

HeikfN G. H. AND MCKAY D. S. (1974) Petrography of Apollo 17 soils. Proc. Lunar Sci. Conf 5th, 843-860.

HeikfN G. H., MCKAY D. S. AND BRown R. W. (1974) Lunar deposits of possible pyroclastic origin. Geochim. Cosmochim Acta 38, 17031718

JAMES O. B. (1992) The ancient lunar crust, Apollo I7 region. In Workshop on Geology of the Apollo 17 Landing Site (eds. G. Ryder, H. II. Schmitt and P. D. Spudis), pp. 17-20. I.PI Tech. Rpt. 92-09. Lunar and Planetary Institute, Houston, Texas.

JAMES O. B. AND HAMMARSTROM J. G. (1977) Petrology of four clasts from consortium breccia 73215. Proc. Lunar Sci. Conf. 8th, 2459-2494.

James O. B. AND MCGeE J. J. (1980) Petrology of mare-type basalt clasts from consortium breccia 73255. Proc. Lunar Planet. Sci. Conf. 11th, $67-86$.

James O. B., Hedenquist J. W., Blancitard D. P., Budain J. R. and COMPSTON W. (1978) Consortium breccia 73255: Petrology, majorand trace-element chemistry, and $\mathrm{Rb}-\mathrm{Sr}$ systematics of aphanitic lithologies. Proc. Lunar Sci. Conf. 9th, 789-819.

Jerde E. A, WARren P. H., Morris, R. V., HiIKEN G. II. AND Vaniman D. T. (1987) A potpourri of regolith breccias: "New" samples from the Apollo 14, 16, and 17 landing sites. Proc. Lumar Planet. Sci. Conf. 17th, J. Geophys. Res. 92, E526-E536.

JOLLIFF B. L. (1993) A monazite-bearing clast in Apollo 17 melt breccia (abstract). Lunar Planet. Sci. 24, 725-726.

JOLLIFF B. L. AND BISHOP K. M. (1993) Apollo 17 materials viewed from 2-4 mm soil particles: Pre-Serenitatis highlands components (abstract). Lunar Planes. Sci. 24, 727-728.

JOLlifF B. L., BISHOP K. M. AND IIASkIN L. A. (1992) Possible petrogenetic associations among igneous components in North Massif soils: Evidence in 2-4-mm soil particles from 76503. In Workshop on Geology of the Apollo 17 Landing Site (cds. G. Ryder, H. II. Schmitt and P. D. Spudis), pp. 24-26. L.PI Tech. Rpt. 92-09. Lunar and Planetary Institute, Houston, Texas.

JOLLIFF B. L., KOROTEV R. L., ROCKOW K. M. AND MASKIN L. A. (1995) Apollo 17 impact-melt breccias: In search of Imbrium components (abstract). Lunar Planet. Sci. 26, 691-692.

KOROTEV R. L. (1990) Correction for loss of metallic iron in "fused bead" analysis of metal-bearing silicate samples (abstract). Lunar Planet. Sci. 21,659 .

KOROTEV R. L. (1991) Gcochemical stratigraphy of two regolith cores from the central highlands of the Moon. Proc. Lunar Planet. Sci. Conf. 21 st, 229-289.

KOROTEV R. L. (1994) Compositional variation in Apollo 16 impact-melt breccias and inferences for the geology and bombardment history of the Central Highlands of the Moon. Geochim. Cosmochim. Acta 58, 39313969.

KOROTEV R. L. AND KREMSER D. T. (1992) Compositional variations in Apollo 17 soils and their relationship to the geology of the TaurusLittrow site. Proc. Lunar Planet. Sci. Conf. 22nd, 275-301. 
KOROTEV R. L., Rockow K. M. AND JOLLIFF B. L. (1995a) Relation of 2-4 $\mathrm{mm}$ regolith breccias to the local soil at Apollo 17 (abstract). Lunar Planet. Sci. 26, 793-794.

KOROTEV R. L., HASKIN L. A. AND Jolliff B. L. (1995b) A simulated geochemical rover mission to the Taurus-Littrow valley of the Moon. J. Geophys. Res. 100, 14 403-14420.

Laul J. C., Simon S. B. AND PAPIKE J. J. (1988) Chemistry and petrology of the Apennine Front, Apollo 15, Part II; Impact melt rocks. Proc. Lunar Planet. Sci. Conf. 18th, 203-217.

laul J. C., Gosselin D. C., Galbreath K. C., Simon S. B. and Papike J. J. (1989) Chemistry and petrology of Apollo 17 highland coarse fines: Plutonic and melt rocks. Proc Lumar Planet Sci Conf 19th, 85-97.

LindSTROM D. J., WENTWORTH S. J., MARTINEZ R. R. AND MCKAY D. S. (1994) Trace element identification of three chemically distinct very low titanium (VLT) basalt glasses from Apollo 17. Geochim. Cosmochim. Acta 58, 1367-1375.

LINDSTROM M. M. AND LINDSTROM D. J. (1986) Lunar granulites and their precursor anorthositic norites of the early lunar crust. Proc. Lunar Planet. Sci. Conf. 16th, J. Geophys. Res. 91, D263-D276.

LindSTROM M. M., MaRVIN U. B., VetTer S. K. and Shervais J. W (1988) Apennine front revisited: Diversity of Apollo 15 highland rock types. Proc. Lunar Planet. Sci. Conf. 18th, 169-185.

LuCHITTA B. K. (1977) Crater clusters and the light mantle at the Apollo 17 site-A result of secondary impact from Tycho. Icarus 30, 80-96.

LUCHITTA B. K. (1992) The Taurus-Littrow dark mantle, light mantle, crater cluster, and scarp. In Workshop on Geology of the Apollo 17 Landing Site (eds. G. Ryder, II. H. Schmitt and P. D. Spudis), p. 31 LPI Tech Rpt 92-09. Lunar and Planetary Institute, Houston, Texas.

LSPET (Lunar Sample Preliminary Examination Team) (1973) Preliminary examination of lunar samples. In Apollo 17 Preliminary Science Report, pp. 7-1-7-46. NASA SP-330.

MEYER C. (1994) Catalog of Apollo 17 Rocks. Volume 4-North Massif. NASAJJohnson Space Center Publication \#26088, Houston, Texas. $644 \mathrm{pp}$.

Morris R. V SCORE R, Dardano C. AND HËIKEN G. (1983) Handbook of Lunar Soils, Part It: Apollo 16-17. NASA/Johnson Space Center Publication $\$ 19069$, Houston, Texas. $913 \mathrm{pp}$

Murali A. V., Ma M. -S., Laul J. C. AND SchimitT R. A. (1977) Chemical composition of breccias, feldspathic basalt and anorthosites from Apollo 15, Apollo 16, Apollo 17, and Luna 20 (abstract). Lunar Sci. 8, $700-702$.

NEAL C R AND TAYLOR L. A. (1992) The Apollo 17 mare basalts: Serenely sampling Taurus-Littrow. In Workshop on Geology of the Apollo 17 Landing Site (eds. G. Ryder, H. H. Schmitt and P. D. Spudis), pp. 37-40. LPI Tech. Rpt. 92-09. Lunar and Planetary Institute, Houston, Texas.

Neal C. R. AND TAYLOR L. A. (1993) Catalog of Apollo 17 Rocks, Vol 2Central Valley, Part I. NASA/Johnson Space Center Publication \#26088, Houston, Texas. $522 \mathrm{pp}$.

Neal C. R., Taylor, L. A., HugheS S. S. and SCHMItT R. A. (1990) The significance of fractional crystallization in the petrogenesis of Apollo 17 Type A and B high-Ti basalts. Geochim. Cosmochim. Acta 54, $1817-1833$.

PIETERS C. M. (1978) Mare basalt types on the front side of the moon: A summary of spectral reflectance data. Proc. Lunar Sci. Conf. 9th, 2825-2849.

PIETERS C. M. AND TAYíor G. J. (1989) Millimeter petrology and kilometer mineralogical exploration of the Moon. Proc. Lunar Planet. Sci. Conf. 19th, 115-125.

RAMBALDI E. (1976) Trace element content of metals from L-group chondrites. Earth Planet. Sci. Lett. 31, 224-238.

RHodes J. M., RODGERS K. V., SHIH C., BaNSAL B. M., Nyquist L. E., WIESMANN H. AND HUBBARD N. J. (1974) The relationship between geology and soil chemistry at the Apollo 17 landing site. Proc. Lunar Sci. Conf 5th, 1097-1117.

Rhodes J. M., HubBard N. J., Wiesmann H., Rodgers K. V., BranNon J. C. AND BANSAL B. M. (1976) Chemistry, classification, and petrogenesis of Apollo 17 mare basalts. Proc. Lunar Sci. Conf. 7th, [467-1489.

RockOw K. M., JOLlifF B. L., KOROTEV R. L. AND HASKIN L. A. (1994a) Geology and distribution of rock types at the Apollo 17 landing site from a 2-4 mm perspective (abstract). Lunar Planet. Sci. 25, 11491150

Rockow K. M., Korotev R. L., JollifF B. L. AND Haskin L. A. (1994b) Compositional differences between impact-melt breccias of the North and South Massifs at Apollo 17 (abstract). Lunar Planet. Sci. 25, II 15$]-1152$

RYDER G. (1990) A distinct yariant of high-titanium mare basalt from the Van Serg core, Apollo 17 landing site. Meteoritics 25, 249-258.
RYDER G. (1992a) The Apollo 17 samples: The massifs and landslide. In Workshop on Geology of the Apollo 17 Landing Site (eds. G. Ryder, H. H. Schmitt and P. D. Spudis), pp. 48-49. LPI Tech. Rpt. 92-09. Lunar and Planetary Institute, Houston, Texas.

RYDER G. (1992b) Impact melt breccias at the Apollo 17 landing site. In Workshop on Geology of the Apollo 77 Landing Site (eds. G. Ryder, H. H. Schmitt and P. D. Spudis), pp. 49-50. LPI Tech. Rpt. 92-09. Lunar and Planetary Institute, Houston, Texas.

RYder G. (1993) Catalog of Apollo I7 Rocks, Vol 1-Stations 2 and 3 (South Massif). NASA/Johnson Space Center Publication \#26088, Houston, Texas. $411 \mathrm{pp}$

RYDER G. AND SPUDIS P. (1987) Chemical composition and origin of Apollo 15 impact melts. Proc. Lunar Planet. Sci. Conf. 17th, J. Geophys. Res. 92, E432-E446.

RYder G. AND STOCKSTILL K. (1995) Chemical variation among Serenitatis impact melt breccia samples in the Taurus-Littrow Valley, Apollo 17 landing site (abstract). Lunar Planet. Sci. 26, 1209-1210.

Ryder G., Stoeser D. B., Marvin U. B., Bower J. F. AND WoOd J. A (1975a) Boulder 1, Station 2, Apollo 17: Petrology and petrogenesis The Moon 14, 327-357.

RYDER G., STOESER D. B., MARVIN U. B. AND BOWER J. F. (1975b) Lunar granites with unique ternary feldspars. Proc. Lunar Sci. Conf. 6th, $435-449$.

RYDER G., LINDSTROM M. AND WILLIS K. (1988) The reliability of macroscopic identification of lunar coarse fines particles and the petrogenesis of 2-4 mm particles in Apennine Front Sample 15243. Proc. Lunar Planet. Sci. Conf. 18th, 219-232.

SAlPas P. A., TAYLOR L. A. AND LindSTROM M. M. (1987) Apollo 17 KREEPy basalts: Evidence for nonuniformity of KREEP. Proc. Lumar Planel. Sci. Conf. 17th, J. Geophys. Res. 92, E340-E348.

Simon S. B., Papike J. J., Gosselin D. C., Laul J. C., Hughes S. S. and SCHMiTT R. A. (1990) Petrology and chemistry of Apollo 17 regolith breccias: A history of mixing of highland and mare regolith. Proc. Lunar Planet. Sci. Conf. 20th, 219-230.

SIMONDS C. H. (1975) Thermal regimes in impact melts and the petrology of the Apollo 17 station 6 boulder. Proc. Lunar Sci. Conf. 6th, 641672.

Spudis P. D. (1992) Basaltic impact melts in the Apollo collection: How many impacts and which events are recorded? In Workshop on Geology of the Apollo 17 Landing Site (eds. G. Ryder, H. H. Schmitt and P. D. Spudis), pp. 55-57. LPI Tech. Rpt. 92-09. Lunar and Planetary Institute, Houston, Texas.

SPUDIS P. D. AND RYDER G. (1981) Apollo 17 impact melts and their relation to the Serenitatis basin. In Multi-Ring Basins, Proc. Lunar Planet. Sci. I2A (eds. P. H. Schultz and R. B. Merrill), pp. 133-I48. Pergamon, New York.

VANIMAN D. T. AND PAPIKE J. J. (1977) Very low Ti (VLT) basalts: A new mare rock type from the Apollo 17 drill core. Proc. Lunar Sci. Conf. 8th, 1443-1471.

Warner R. D., Taylor G. J., Keil K., Planner H. N., Nehru C. E., Ma M.S. AND SCHMITT R. A. (1978) Green glass vitrophyre 78526: An impact melt of very low-Ti mare basalt composition. Proc. Lunar Sci. Conf. 9th, 547-563.

WARREN P. H. (1993) A concise compilation of petrologic information on possibly pristine nonmare Moon rocks. Am. Min. 78, 360-376.

WARREN P. H. AND WASSON J. T. (1978) Compositional-petrographic investigation of pristine non-mare rocks. Proc. Lunar Planet. Sci. Conf 9th, 185-217.

WarReN P. H., Shirley D. N. AND KallemeYN G. W. (1986) A potpourti of pristine moon rocks, including a VHK mare basalt and a unique, augite-rich Apollo 17 anorthosite. Proc. Lunar Planet. Sci. Conf. 16th, J Geophys. Res. 91, D319-D330.

Warken P. H., Jerde E. A. AND KallemeYn G. W. (1987) Pristine moon rocks: A "large" felsite and a metal-rich ferroan anorthosite. Proc. Lunar Planet Sci Conf 17th, In $J$ Geophys. Res. 92, E303-E313.

Warren P. H., Jerde E. A. ANd KallemeYn G. W. (1991) Pristine Moon rocks: Apollo 17 anorthosites. Proc. Lunar Planet. Sci. Conf. 21, 5161.

WentWorth S., TAYLOR G. J., WARNer R. D., KeIL K. MA M. -S. AND SCHMITT R. A. (1979) The unique nature of Apollo 17 VLT mare basalts. Proc. Lunar Sci. Conf. 10th, 207-223.

WINZER S. R., NAVA D. F SCHUHMANN P J LUM R K L SCHUHMANN S., LindSTRom, M. M., LindSTROM D. J. AND PhilpotTS J. A. (1977) The Apollo 17 "melt sheet": Chemistry, age and $\mathrm{Rb} / \mathrm{Sr}$ systematics. Earth Planet. Sci Lett 33, 389-400.

Wolfe E. W., Bailey N. G., Lucchitta B. K., Muehlaerger W. R., SCOTT D. H., SUTTON R. L. AND WILSHIRE H. G. (1981) The geologic investigation of the Taurus-Littrow Valley: Apollo 17 landing site. U.S. Geol. Surv. Prof. Paper 1080. 280 pp. 

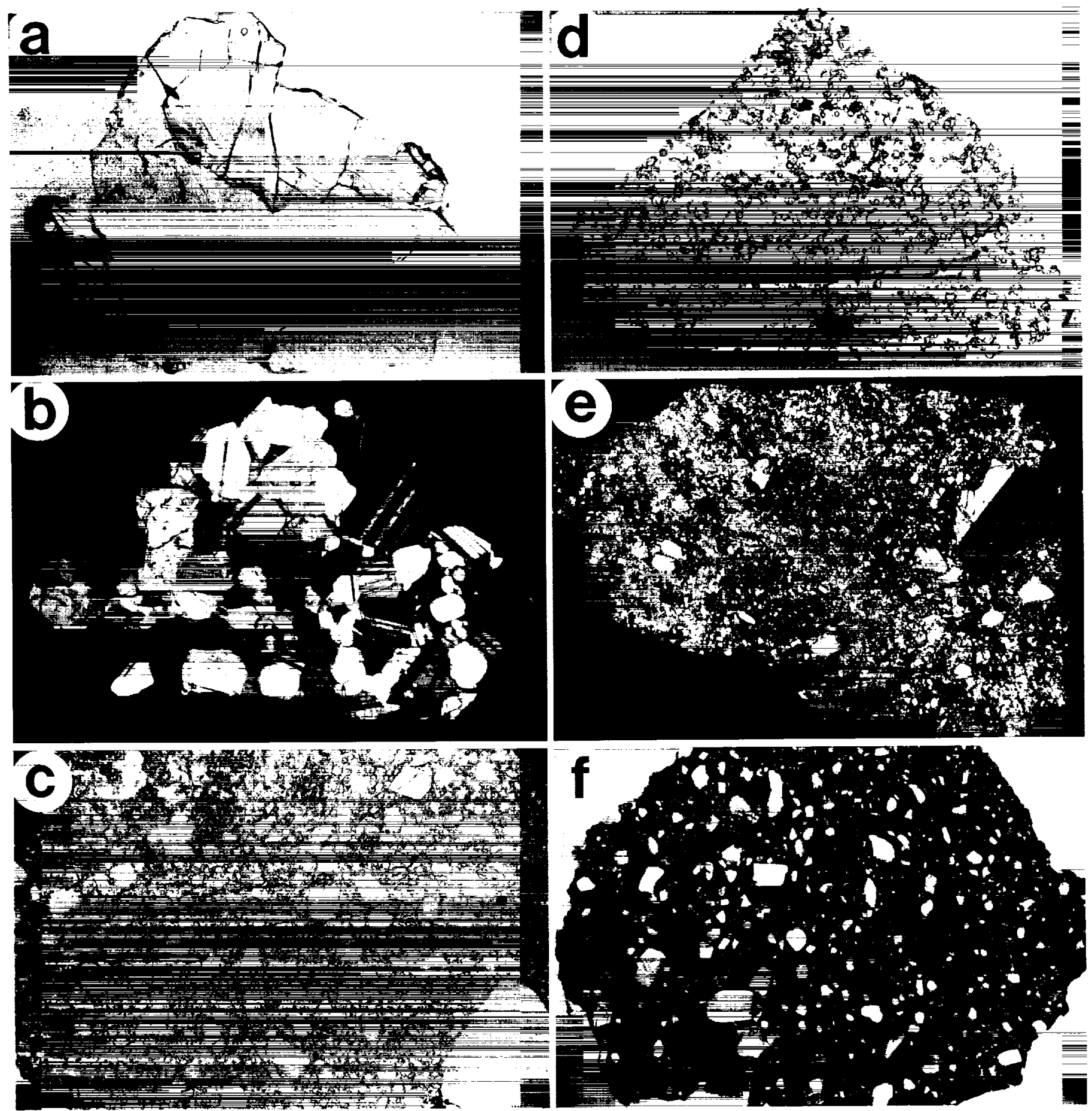

FIG. Al. Transmitted light photomicrographs of representative $2 \mathrm{~mm}-4 \mathrm{~mm}$ lithic fragments. Field of view (FOV) is $\sim 3 \mathrm{~mm}$ unless otherwise noted. (a) Troctolitic anorthosite fragment 76503,7065 , in plane light ( $P L, F O V=1.6 \mathrm{~mm})$. Large central grain is coarse plagioclase, clouded with inclusions. Large mafic grain (top, right) is olivine with a partial rim of orthopyroxene (pyroxene cleavage) separating olivine from plagioclase. Mafic grain (lower left) is orthopyroxene. Mineral compositions and bulk composition (Table A1) place this assemblage in the magnesian suite of lunar plutonic rocks. (b) Anorthosite 72503,7085 under crossed polarizers (CP). Texture is granoblastic (recrystallized) and minor poikilitic pyroxene is present. Plagioclase and pyroxene compositions indicate that this fragment belongs to the ferroan-anorthositic suite. (c) Granulitic breccia 76503,7079 (PL, FOV $=1.6 \mathrm{~mm}$ ). Texture is very fine grained and composition is magnesian (Table A2). (d) Granulitic breccia 76503, 7084 (PL). Granoblastic texture coarser than (c); composition is ferroan (Table A2). (c) Poikilitic-matrix impact-melt breccia, 72503,7202 (partial CP). Coarse poikiloblastic texture appears as light and dark regions of matrix. (ก) Aphanitic-matrix impact-melt breccia, 72503,7104 (PL), (Table A3c). This figure is continued on the following page. 
FIG. AI (continued).
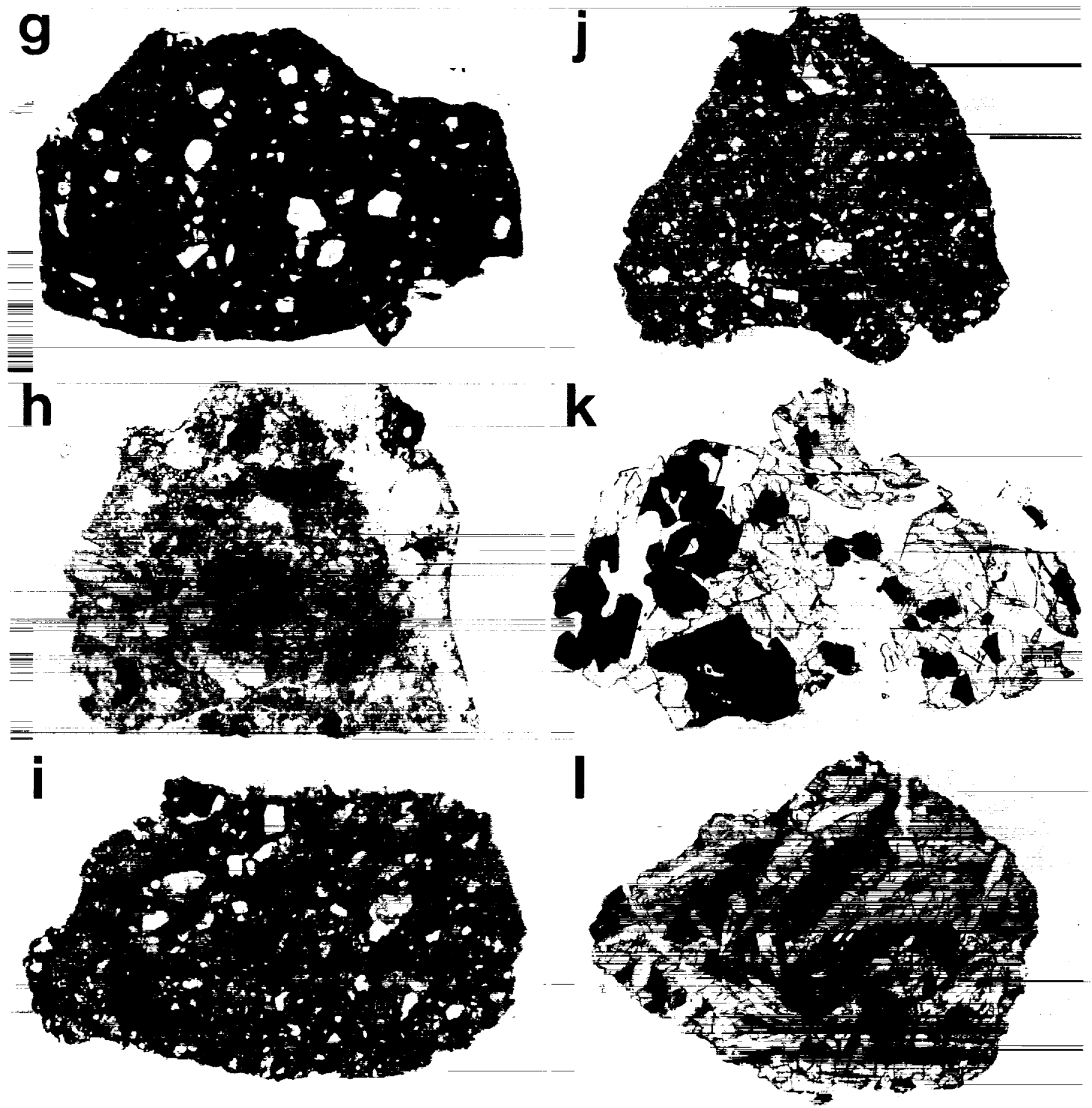

Fig. Al, continued. Transmitted light photomicrographs of representative $2 \mathrm{~mm}-4 \mathrm{~mm}$ lithic fragments. Field of view (FOV) is $-3 \mathrm{~mm}$ unless atherwise noted. (g) ITE-rich impact-melt breccia 76503,7100 (PL), (Table A3b). Matrix is aphanitic. (h) "Non-mare" regolith breccia, 72503,7044 (PL), (Table A4). The "non-mare" designation is based on low $\mathrm{Sc}$ concentration $(12.5 \mu \mathrm{g} / \mathrm{g})$ and absence of obvious mare-basalt lithic clasts. Right edge of the fragment consists of agglutinitic glass. (i) "Typical" regolith breccia 72503,7016 (PL). Chemical composition (Table A4) is similar to that of the corresponding <1 $\mathrm{mm}$ fines (72501, Table 1). (j) Orange-glass regolith breccia 76503,7043 (PL), (Table A5). (k) High-Ti mare basalt 76503,7101 (Table $\lambda 5$ ). Colorless grains are plagioclase, forming a coarse, poikilitic mass enclosing pyroxene and ilmenite; pyroxene grains are mostly titan-augite; and opaque grains are FeTi oxide, mostly ilmenite. (l) Low-Ti basalt 72443,7053. Porphyritic texture with phenocrysts of elongate clinopyroxene and finer-grained, less abundant plagioclase laths. Dark areas include fine-grained, poikilitic ilmenite, spongy-textured mesostasis, and minor troilite. Section is slightly thicker than $30 \mu \mathrm{m}$. 
TABLE A1. Highland lithic fragments, ITE-poor, other than granulitic breccias.

\begin{tabular}{|c|c|c|c|c|c|c|c|c|c|c|c|c|c|}
\hline \multirow{2}{*}{ Sample } & & \multicolumn{8}{|c|}{ Troctolitic Anorthosite } & \multicolumn{4}{|c|}{ Other } \\
\hline & & $\begin{array}{l}76503 \\
, 7073\end{array}$ & $\begin{array}{l}76503 \\
, 7237\end{array}$ & $\begin{array}{l}76503 \\
, 7076\end{array}$ & $\begin{array}{l}76503 \\
, 7083\end{array}$ & $\begin{array}{l}76503 \\
, 7230\end{array}$ & $\begin{array}{l}76503 \\
, 7065\end{array}$ & $\begin{array}{c}76503 \\
, 7075\end{array}$ & $\begin{array}{l}76503 \\
, 7229\end{array}$ & $\begin{array}{l}76503 \\
, 7057\end{array}$ & $\begin{array}{l}76503 \\
, 7069\end{array}$ & $\begin{array}{l}76503 \\
, 7109\end{array}$ & $\begin{array}{c}76503^{*} \\
, 7155\end{array}$ \\
\hline \multicolumn{2}{|c|}{ Description } & $F s p B x$ & $\begin{array}{c}\text { Fsp Bx } \\
+\mathrm{Ol}\end{array}$ & $\begin{array}{l}\text { Plag } \\
+\mathrm{OI}\end{array}$ & $\begin{array}{l}\text { Troc- } \\
\text { Gls Bx }\end{array}$ & $\begin{array}{l}\text { Plag } \\
+01\end{array}$ & $\begin{array}{l}\text { Troc- } \\
\text { Anor }\end{array}$ & $\begin{array}{l}\text { Troc- } \\
\text { Anor }\end{array}$ & $\begin{array}{c}\text { Oliv } \\
+ \text { Plag }\end{array}$ & $\begin{array}{l}\text { Troc- } \\
\text { Gls Bx }\end{array}$ & $\begin{array}{c}\text { Fsp Bx } \\
\text { Gls Mtrx }\end{array}$ & $\begin{array}{l}\mathrm{NA} / \mathrm{AG} \mathrm{Cl} \\
+ \text { GIs Vns }\end{array}$ & $\begin{array}{l}\text { Impact } \\
\text { Melt Gls }\end{array}$ \\
\hline \multicolumn{2}{|c|}{ Mass (mg) } & 7.56 & 5.46 & 5.09 & 25.63 & 8.26 & 20.40 & 19.82 & 16.56 & 25.27 & 12.99 & 27.88 & 13.36 \\
\hline \multicolumn{14}{|c|}{ Major-element Oxides } \\
\hline $\mathrm{SiO}_{2}$ & FB & 44.3 & 44.6 & 44.5 & 42.4 & 44.9 & & & & 45.0 & 46.6 & 45.2 & 43.9 \\
\hline $\mathrm{TiO}_{2}$ & FB & 0.04 & 0.01 & 0.04 & 0.04 & 0.05 & & & & 0.21 & 0.23 & 0.35 & 0.54 \\
\hline $\mathrm{Al}_{2} \mathrm{O}_{3}$ & FB & 33.1 & 31.5 & 30.5 & 22.1 & 20.5 & & & & 19.7 & 21.0 & 25.8 & 21.4 \\
\hline $\mathrm{Cr}_{2} \mathrm{O}_{3}$ & INAA & 0.019 & 0.080 & 0.077 & 0.087 & 0.054 & 0.124 & 0.085 & 0.138 & 0.168 & 0.19 & 0.132 & 0.14 \\
\hline $\mathrm{Cr}_{2} \mathrm{O}_{3}$ & FB & 0.02 & 0.08 & 0.05 & 0.10 & 0.08 & & & & 0.16 & 0.22 & 0.16 & 0.15 \\
\hline $\mathrm{FeO}$ & INAA & 0.68 & 1.42 & 1.74 & 4.22 & 4.72 & 3.5 & 2.9 & 10.51 & 7.28 & 6.72 & 4.74 & 5.63 \\
\hline $\mathrm{FeO}$ & FB & 0.76 & 1.42 & 1.54 & 4.76 & 4.95 & & & & 7.76 & 6.96 & 4.74 & 5.98 \\
\hline $\mathrm{MnO}$ & FB & $<0.01$ & $<0.01$ & 0.02 & 0.07 & 0.05 & & & & 0.09 & 0.10 & 0.08 & 0.09 \\
\hline $\mathrm{MgO}$ & FB & 2.99 & 5.20 & 6.52 & 17.1 & 18.8 & & & & 15.8 & 13.5 & 7.90 & 15.2 \\
\hline $\mathrm{CaO}$ & INAA & 18.4 & 17.3 & 15.9 & 12.6 & 11.7 & 12.8 & 14.9 & 2.82 & 11.2 & 11.6 & 15.0 & 12.7 \\
\hline $\mathrm{CaO}$ & $\mathrm{FB}$ & 18.3 & 17.5 & 16.8 & 12.2 & 11.1 & & & & 11.3 & 11.5 & 15.0 & 12.3 \\
\hline $\mathrm{Na}_{2} \mathrm{O}$ & INAA & 0.38 & 0.34 & 0.33 & 0.25 & 0.24 & 0.25 & 0.28 & 0.057 & 0.44 & 0.45 & 0.41 & 0.31 \\
\hline $\mathrm{Na}_{2} \mathrm{O}$ & FB & 0.38 & 0.32 & 0.30 & 0.21 & 0.21 & & & & 0.43 & 0.43 & 0.38 & 0.29 \\
\hline $\mathrm{K}_{2} \mathrm{O}$ & FB & 0.04 & 0.04 & 0.04 & 0.03 & 0.01 & & & & 0.08 & 0.09 & 0.06 & 0.08 \\
\hline $\mathrm{P}_{2} \mathrm{O}_{5}$ & FB & 0.01 & $0.0 \mathrm{I}$ & 0.06 & 0.01 & 0.02 & & & & 0.08 & 0.04 & 0.03 & 0.04 \\
\hline Total & (FB) & 100.0 & 100.7 & 100.3 & 98.9 & 100.6 & & & & 100.5 & 100.6 & 99.7 & 99.9 \\
\hline $\mathrm{Mg}^{\prime}$ & & 0.87 & 0.87 & 0.88 & 0.86 & 0.87 & & & & 0.78 & 0.78 & 0.75 & 0.82 \\
\hline \multicolumn{14}{|c|}{ Trace Elements $(\mu \mathrm{g} / \mathrm{g})$} \\
\hline $\mathrm{Sc}$ & & 0.58 & 0.99 & 1.89 & 1.87 & 1.35 & 2.88 & 0.95 & 2.68 & 6.38 & 7.18 & 8.90 & 7.78 \\
\hline $\mathrm{Cr}$ & & 133 & 547 & 524 & 594 & 372 & 851 & 581 & 945 & 1152 & 1300 & 906 & 928 \\
\hline Co & & 3.5 & 9.4 & 10.4 & 21.6 & 21.4 & 20.36 & 18.41 & 48.6 & 24.4 & 20.6 & 15.7 & 24.4 \\
\hline $\mathrm{Ni}$ & & $<16$ & 17 & 22 & 24 & 20 & 24 & 35 & 53 & 78 & 59 & 110 & 88 \\
\hline $\mathrm{Zn}$ & & I & 5 & $<5$ & -- & 5 & $<5$ & $<3$ & 7 & 4 & 10 & 9 & $\ldots$ \\
\hline $\mathrm{Rb}$ & & 1.7 & $<5$ & $<2$ & 1.7 & $<4$ & $<3$ & 1.0 & 4 & 3.7 & $<5$ & 3.0 & $<6$ \\
\hline $\mathrm{Sr}$ & & 177 & 160 & 164 & 127 & 122 & 133 & 152 & 25 & 148 & 149 & 166 & 137 \\
\hline $7 \mathrm{r}$ & & $<30$ & $<60$ & 25 & $<17$ & $<35$ & 17 & $<11$ & $<30$ & 77 & 78 & 59 & 77 \\
\hline $\mathrm{Cs}$ & & 0.14 & 0.06 & 0.03 & 0.07 & 0.07 & 0.032 & 0.071 & 0.05 & 0.59 & 0.39 & 0.09 & 0.09 \\
\hline $\mathrm{Ba}$ & & 67 & 54 & 49 & 34 & 28 & 38 & 33.7 & 8 & 83 & 89 & 76 & 79 \\
\hline $\mathrm{I}, \mathrm{a}$ & & 2.32 & I.8I & 2.92 & 1.76 & 1.69 & 2.11 & 1.52 & 0.467 & 6.56 & 7.22 & 5.12 & 6.41 \\
\hline $\mathrm{Cc}$ & & 5.2 & 4.1 & 7.5 & 4.4 & 4.3 & 5.15 & 3.49 & 1.25 & 16.9 & 18.2 & 13.1 & 16.5 \\
\hline $\mathrm{Nd}$ & & 3.3 & 1.9 & 4.2 & 3.0 & 1.9 & 3 & 2 & $<1.8$ & 11.4 & 10.7 & 7.3 & 9.7 \\
\hline $\mathrm{Sm}$ & & 0.64 & 0.57 & 1.24 & 0.64 & 0.60 & 0.90 & 0.44 & 0.214 & 2.85 & 3.09 & 2.30 & 2.93 \\
\hline Eu & & 1.20 & 1.16 & 1.08 & 0.81 & 0.74 & 0.84 & 0.99 & 0.166 & 1.10 & 1.15 & 0.99 & 0.96 \\
\hline $\mathrm{Tb}$ & & 0.10 & 0.10 & 0.25 & 0.13 & 0.10 & 0.18 & 0.07 & 0.043 & 0.57 & 0.64 & 0.48 & 0.60 \\
\hline $\mathrm{Yb}$ & & 0.25 & 0.34 & 0.67 & 0.52 & 0.35 & 0.75 & 0.29 & 0.43 & 2.43 & 2.67 & 1.96 & 2.17 \\
\hline $\mathrm{Lu}$ & & 0.025 & $0.04 \mathrm{I}$ & 0.083 & 0.074 & 0.046 & 0.10 & 0.04 & 0.087 & 0.337 & 0.37 & 0.269 & 0.294 \\
\hline $\mathrm{Hf}$ & & 0.09 & 0.22 & 0.38 & 0.35 & 0.13 & 0.43 & 0.15 & 0.19 & 2.11 & 2.02 & 1.72 & 2.12 \\
\hline $\mathrm{Ta}$ & & 0.02 & 0.02 & 0.02 & 0.03 & 0.03 & 0.03 & 0.03 & 0.02 & 0.30 & 0.20 & 0.38 & 0.29 \\
\hline $\operatorname{Ir}(\mathrm{ng} / \mathrm{g}$ & & $<3$ & $<2$ & $<3$ & $<0.9$ & $<2$ & $<1.3$ & $<0.8$ & $<1.1$ & 3.4 & 4.9 & 4.2 & 2.4 \\
\hline$\Lambda u(n g$ & & $<4$ & -- & - & $<3$ & $<1.4$ & 1.2 & -- & $<0.5$ & $<4$ & $<3$ & $<1.5$ & $<3$ \\
\hline Th & & 0.08 & 0.05 & 0.47 & 0.18 & 0.21 & 0.25 & 0.10 & 0.07 & 1.4 & 1.5 & 0.96 & 0.98 \\
\hline $\mathrm{U}$ & & $<0.2$ & 0.06 & 0.10 & $<0.3$ & $<0.3$ & 0.05 & 0.04 & $<0.06$ & 0.41 & 0.34 & 0.29 & 0.29 \\
\hline Sample & Iount & fbo & fbo & fbo & $\mathrm{ts} 3 \mathrm{C}$ & fbo & $\operatorname{ts} 3 A$ & $\mathrm{ts} 3 \mathrm{~B}$ & na & $\mathrm{ts} 4 \mathrm{~B}$ & $\mathrm{ts} 20 \mathrm{~A}$ & $\mathrm{ts} 4 \mathrm{D}$ & $\mathrm{ts} 20 \mathrm{C}$ \\
\hline INAA & & 273.129 & 277.113 & 273.132 & 273.139 & 277.106 & 273.121 & 273.131 & 277.105 & 273.113 & 273.125 & 274.015 & 274.111 \\
\hline
\end{tabular}

$\mathrm{Mg}^{\prime}=\operatorname{molar} \mathrm{MgO} /(\mathrm{MgO}+\mathrm{FeO}(\mathrm{FB}))$.

${ }^{*}$ Major-element composition of 76503,7155 determined from electron microprobe analysis of impact glass.

$\ldots=$ no value, $t s=$ thin section (mount \#), fbo $=$ fused bead only, Anor $=$ anorthosite, Gls $=$ glass, Fsp $=$ feldspathic, $\mathrm{NA}=$ noritic anorthosite, $\mathrm{Bx}=$ breccia,

$\mathrm{AG}=$ anorthositic gabbro, $\mathrm{OI}=$ olivine, $\mathrm{Cl}=$ clasts, $\mathrm{Plag}=$ plagioclase, $\mathrm{Gls} \mathrm{Vn}=$ glass veins, $\mathrm{Troc}=$ troctolitic 


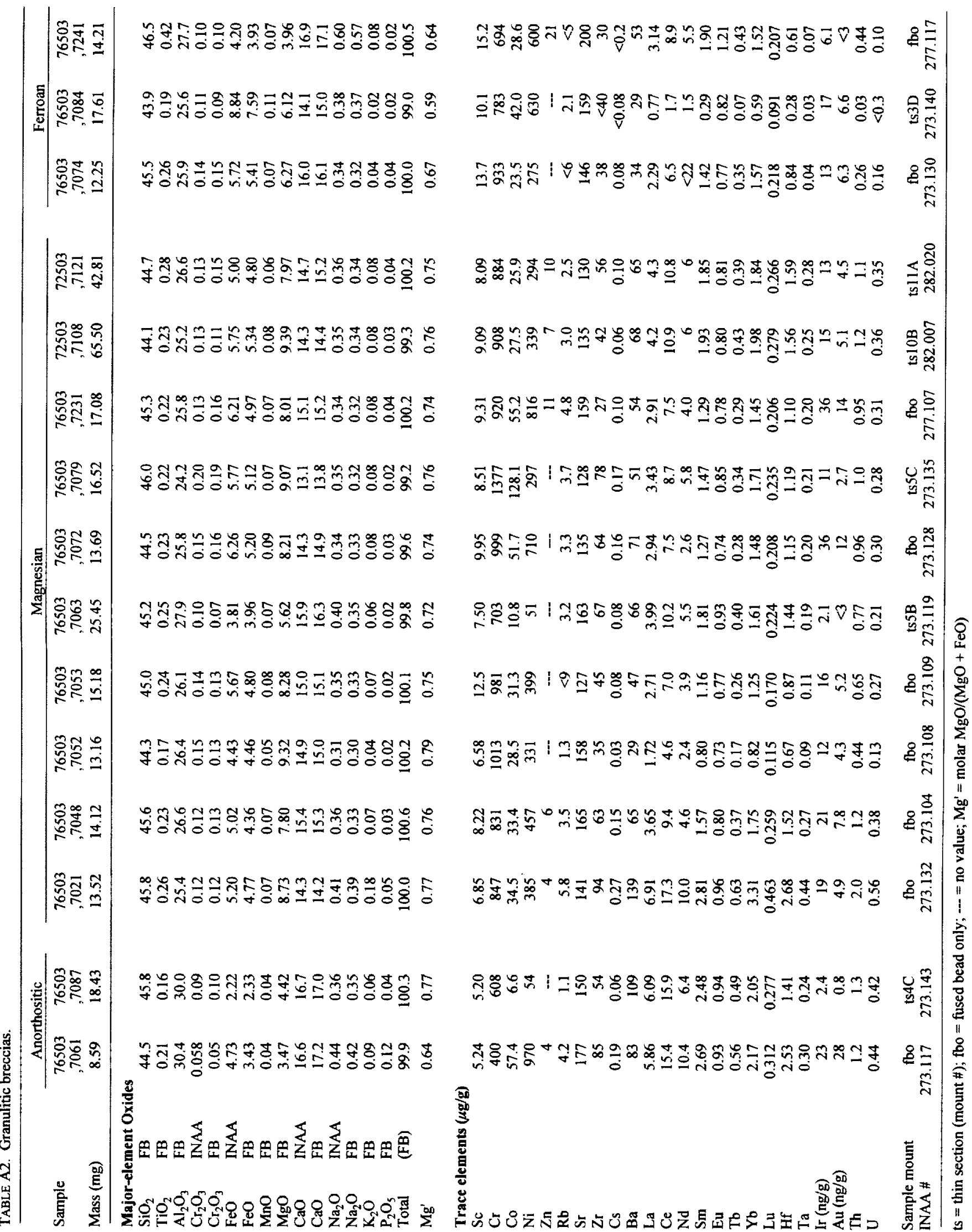


Table A3a. Impact-melt breccias: poikilitic or granular-matrix.

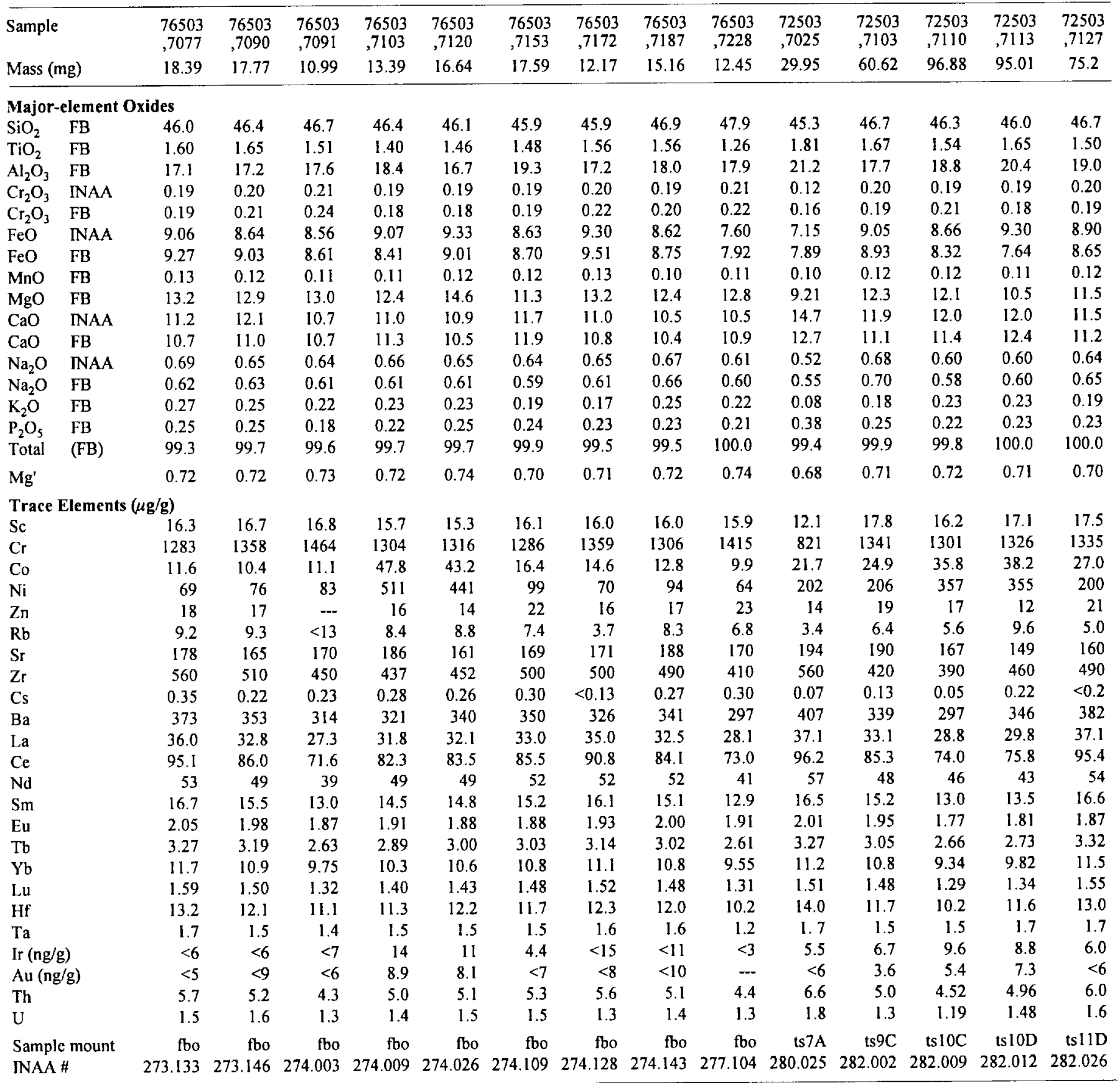

ts = thin section (mount $\#$ ); fbo = fused bead only;.$-=$ no value; $\mathrm{Mg}^{\prime}=$ molar $\mathrm{MgO} /(\mathrm{MgO}+\mathrm{FeO})$ 
TABLE A3b, Impact-melt breccias: Incompatible-element rich.

\begin{tabular}{|c|c|c|c|c|c|c|c|c|c|c|c|}
\hline \multicolumn{2}{|c|}{ Sample } & $\begin{array}{c}76503 \\
, 7097 \\
\mathrm{cl-r}\end{array}$ & $\begin{array}{l}76503 \\
, 7100\end{array}$ & $\begin{array}{l}76503 \\
, 7133\end{array}$ & $\begin{array}{l}72503 \\
, 7005\end{array}$ & $\begin{array}{l}72503 \\
, 7026 \\
\text { Ol-cl-r }\end{array}$ & $\begin{array}{l}72503 \\
, 7045\end{array}$ & $\begin{array}{l}72503 \\
, 7069\end{array}$ & $\begin{array}{l}72503 \\
, 7099\end{array}$ & $\begin{array}{l}72503 \\
, 7126\end{array}$ & $\begin{array}{l}72443 \\
, 7064\end{array}$ \\
\hline \multicolumn{2}{|c|}{ Mass (mg) } & 24.04 & 29.12 & 11.88 & 17.12 & 22.09 & 23.21 & 18.90 & 16.65 & 69.10 & 21.16 \\
\hline \multicolumn{12}{|c|}{ Major-element Oxides } \\
\hline $\mathrm{SiO}_{2}$ & $\mathrm{FB}$ & 46.0 & 47.4 & 48.9 & 47.2 & 44.4 & 49.2 & 47.1 & 47.0 & 47.0 & 46.9 \\
\hline $\mathrm{TiO}_{2}$ & $\mathrm{FB}$ & $\mathrm{I} .90$ & 2.14 & 1.35 & 1.73 & 1.82 & 1.10 & 0.97 & 1.78 & 0.92 & 2.63 \\
\hline $\mathrm{Al}_{2} \mathrm{O}_{3}$ & $\mathrm{FB}$ & $\mathrm{I} 6.9$ & 15.9 & 18.1 & 16.7 & 13.4 & 18.8 & 19.4 & 17.5 & 19.3 & 16.4 \\
\hline $\mathrm{Cr}_{2} \mathrm{O}_{3}$ & INAA & 0.18 & 0.20 & 0.17 & 0.24 & 0.19 & 0.20 & 0.21 & 0.20 & 0.25 & 0.16 \\
\hline $\mathrm{Cr}_{2} \mathrm{O}_{3}$ & $\mathrm{FB}$ & 0.19 & 0.20 & 0.19 & 0.22 & 0.19 & 0.18 & 0.23 & 0.20 & 0.24 & 0.16 \\
\hline $\mathrm{FeO}$ & NAA & 9.40 & 9.95 & 8.84 & 10.1 & 12.7 & 9.35 & 8.75 & 9.89 & 9.08 & 11.8 \\
\hline $\mathrm{FeO}$ & $\mathrm{FB}$ & 9.35 & 10.2 & 9.02 & 10.1 & 13.0 & 9.03 & 9.29 & 9.18 & 9.49 & 11.4 \\
\hline $\mathrm{MnO}$ & $\mathrm{FB}$ & 0.12 & 0.12 & 0.14 & 0.14 & 0.15 & 0.12 & 0.12 & 0.13 & 0.14 & 0.17 \\
\hline $\mathrm{MgO}$ & FB & 12.1 & 10.9 & 9.86 & 12.0 & 17.4 & 7.97 & 8.92 & 11.4 & 9.42 & 9.83 \\
\hline $\mathrm{CaO}$ & INAA & 10.8 & 11.3 & 10.4 & 11.5 & 9.40 & I 1.5 & 11.2 & 11.8 & 12.2 & 10.1 \\
\hline $\mathrm{CaO}$ & FB & 10.9 & 10.9 & 11.1 & 10.9 & 8.56 & 11.2 & 11.9 & 10.8 & $\mathrm{I} 2.1$ & 10.5 \\
\hline $\mathrm{Na}_{2} \mathrm{O}$ & INAA & 0.76 & 0.89 & 0.80 & 0.66 & 0.56 & 1.00 & 0.55 & 0.69 & 0.50 & 0.84 \\
\hline $\mathrm{Na}_{2} \mathrm{O}$ & FB & 0.77 & 0.82 & 0.77 & 0.65 & 0.52 & 1.02 & 0.57 & 0.68 & 0.53 & 0.76 \\
\hline $\mathrm{K}_{2} \mathrm{O}$ & FB & 0.26 & 0.32 & 0.41 & 0.40 & 0.16 & 0.52 & 0.35 & 0.42 & 0.27 & 0.10 \\
\hline $\mathrm{P}_{2} \mathrm{O}_{5}$ & $\mathrm{FB}$ & 0.29 & 0.36 & 0.33 & 0.42 & 0.22 & 0.49 & 0.36 & 0.26 & 0.37 & 0.20 \\
\hline Total & (FB) & 98.7 & 99.2 & 100.1 & 100.5 & 99.9 & 99.6 & 99.2 & 99.3 & 99.8 & 99.1 \\
\hline $\mathrm{Mg}^{\prime}$ & & 0.70 & 0.66 & 0.66 & 0.68 & 0.70 & 0.61 & 0.63 & 0.69 & 0.64 & 0.61 \\
\hline \multicolumn{12}{|c|}{ Trace Elements $(\mu \mathrm{g} / \mathrm{g})$} \\
\hline $\mathrm{Se}$ & & 17.6 & 21.4 & 16.6 & 21.8 & 18.3 & $2 \mathrm{I} .2$ & 19.9 & 19.0 & 21.9 & 21.8 \\
\hline $\mathrm{Cr}$ & & 1261 & 1344 & 1191 & 1628 & 1279 & 1379 & 1449 & I33I & 1683 & 1090 \\
\hline $\mathrm{Co}$ & & 26.7 & 18.6 & 19.5 & 22.3 & 40.3 & 22.5 & 32.3 & 28.8 & 24.9 & 31.8 \\
\hline $\mathrm{Ni}$ & & 110 & 70 & 161 & 160 & 410 & 120 & 240 & 230 & 120 & 210 \\
\hline $\mathrm{Zn}$ & & 23 & 24 & 22 & 25 & 13 & 23 & 30 & 23 & 22 & 17 \\
\hline $\mathrm{Rb}$ & & 9.0 & 11.3 & 15.0 & 12.0 & 8.0 & 16.0 & 13.3 & 17 & 9.0 & $<12$ \\
\hline $\mathrm{Sr}$ & & 140 & 187 & 196 & 170 & 150 & 140 & 140 & 200 & 130 & 200 \\
\hline $\mathrm{Zr}$ & & 500 & 680 & 645 & 790 & 490 & 980 & 920 & 1010 & 590 & 800 \\
\hline Cs & & 0.30 & 0.47 & 0.58 & 0.37 & 0.14 & 0.90 & 0.51 & 0.66 & 0.29 & 0.24 \\
\hline $\mathrm{Ba}$ & & 380 & 527 & 591 & 426 & 403 & 933 & 601 & 579 & 432 & 440 \\
\hline La & & 36.4 & 50.3 & 46.6 & 55.7 & 41.8 & 71.0 & 65.8 & 53.8 & 45.0 & 41.1 \\
\hline $\mathrm{Ce}$ & & 93.8 & 130 & 120 & 146 & 108 & 182 & 167 & 139 & 115 & 108 \\
\hline $\mathrm{Nd}$ & & 55 & 76 & 69 & 86 & 65 & 102 & 97 & 76 & 67 & 64 \\
\hline $\mathrm{Sm}$ & & 16.5 & 22.5 & 20.6 & 26.3 & 19.4 & 31.4 & 28.6 & 24.1 & 20.1 & 20.5 \\
\hline Eu & & 1.78 & 2.14 & 2.13 & 2.10 & 1.81 & 2.03 & 1.88 & 2.02 & 1.59 & 243 \\
\hline $\mathrm{Tb}$ & & 3.24 & 4.51 & 4.20 & 5.18 & 3.99 & 6.39 & 5.64 & 4.86 & 4.00 & 4.12 \\
\hline $\mathrm{Yb}$ & & 11.5 & 15.9 & 15.4 & 16.7 & 14.0 & 22.8 & 19.3 & 17.6 & 13.8 & 14.6 \\
\hline $\mathrm{Lu}$ & & 1.59 & 2.14 & 2.09 & 2.25 & 1.94 & 3.10 & 2.56 & 239 & 1.86 & 1.97 \\
\hline IIf & & 12.2 & 17.6 & 16.4 & 18.5 & 13.3 & 24.4 & 22.0 & 24.8 & 14.7 & 18.9 \\
\hline $\mathrm{Ta}$ & & 1.5 & 2.2 & 2.2 & 2.0 & 2.2 & 2.9 & 2.1 & 2.8 & 1.7 & 1.6 \\
\hline \multicolumn{2}{|c|}{ Ir (ng/g) } & $<12$ & $<7$ & 3.7 & $<6$ & 8.1 & 2.7 & 9.7 & 8.3 & 2.1 & 7 \\
\hline \multicolumn{2}{|c|}{$\mathrm{Au}(\mathrm{ng} / \mathrm{g})$} & $<12$ & $<11$ & 2.3 & $<11$ & 6.0 & 3.0 & 5.0 & 6 & $<5$ & $<10$ \\
\hline \multicolumn{2}{|c|}{ Th } & 5.4 & 7.8 & 8.5 & 7.5 & 6.7 & 13.7 & 10.1 & $\mathrm{I} 1.2$ & 7.1 & 2.75 \\
\hline \multicolumn{2}{|l|}{$\mathrm{U}$} & 1.6 & 2.1 & 2.4 & 2.1 & 1.7 & 4.0 & 2.8 & 3.1 & 1.9 & 0.99 \\
\hline \multicolumn{2}{|c|}{ Sample mount } & ts7B & IsID & fbo & ts $7 \mathrm{C}$ & ts $8 \AA$ & $\mathrm{ts} 8 \mathrm{C}$ & ts $9 \mathrm{~A}$ & ts $17 F$ & ts $11 \mathrm{C}$ & $\operatorname{ts} 15 \mathrm{D}$ \\
\hline \multicolumn{2}{|c|}{ INAA \# } & 274.003 & 274.006 & 274.039 & 280.005 & 280.026 & 280.045 & 280.117 & 280.147 & 282.02 & 287.141 \\
\hline
\end{tabular}

ts = thin section (mount \#); fho = fused bead only; cl-r = clast-rich; $\mathrm{Ol}=$ olivine. 
TABLE A3c. Impact-melt breccias: aphanitic.

\begin{tabular}{|c|c|c|c|c|c|c|}
\hline \multicolumn{2}{|l|}{ Sample } & $\begin{array}{l}76503 \\
, 7152\end{array}$ & $\begin{array}{l}72503 \\
, 7042\end{array}$ & $\begin{array}{l}72503 \\
, 7104\end{array}$ & $\begin{array}{l}72503 \\
, 7106\end{array}$ & $\begin{array}{l}72443 \\
, 7059\end{array}$ \\
\hline \multicolumn{2}{|c|}{ Mass (mg) } & 14.34 & 37.67 & 57.91 & 36.81 & 24.08 \\
\hline \multicolumn{7}{|c|}{ Major-element Oxides } \\
\hline $\mathrm{SiO}_{2}$ & FB & 48.5 & 46.3 & 46.3 & 46.2 & 46.8 \\
\hline $\mathrm{TiO}_{2}$ & FB & 0.80 & 0.64 & 0.62 & 0.71 & 1.11 \\
\hline $\mathrm{Al}_{2} \mathrm{O}_{3}$ & $\mathrm{FB}$ & 18.1 & 22.9 & 21.6 & 22.6 & 19.1 \\
\hline $\mathrm{Cr}_{2} \mathrm{O}_{3}$ & INAA & 0.20 & 0.19 & 0.19 & 0.20 & 0.25 \\
\hline $\mathrm{Cr}_{2} \mathrm{O}_{3}$ & $\mathrm{FB}$ & 0.22 & 0.19 & 0.19 & 0.21 & 0.26 \\
\hline $\mathrm{FeO}$ & INAA & 8.49 & 7.08 & 6.78 & 7.49 & 9.27 \\
\hline $\mathrm{FeO}$ & $\mathrm{FB}$ & 8.50 & 6.59 & 6.73 & 7.05 & 8.86 \\
\hline $\mathrm{MnO}$ & $\mathrm{FB}$ & 0.11 & 0.09 & 0.09 & 0.10 & 0.14 \\
\hline MgO & $\mathrm{FB}$ & 10.2 & 9.36 & 11.0 & 9.15 & 11.0 \\
\hline $\mathrm{CaO}$ & IN $\Lambda A$ & 11.2 & 13.5 & 12.6 & 13.1 & 11.7 \\
\hline $\mathrm{CaO}$ & $\mathrm{FB}$ & 11.8 & 13.1 & $\mathrm{I} 2.3$ & 13.0 & 11.6 \\
\hline $\mathrm{Na}_{2} \mathrm{O}$ & INAA & 0.68 & 0.52 & 0.45 & 0.49 & 0.55 \\
\hline $\mathrm{Na}_{2} \mathrm{O}$ & FB & 0.64 & 0.51 & 0.44 & 0.50 & 0.51 \\
\hline $\mathrm{K}_{2} \mathrm{O}$ & $\mathrm{FB}$ & 0.10 & 0.19 & 0.18 & 0.22 & 0.21 \\
\hline $\mathrm{P}_{2} \mathrm{O}_{5}$ & $\mathrm{FB}$ & 0.23 & 0.16 & 0.15 & 0.22 & 0.23 \\
\hline Total & (FB) & 99.3 & 100.1 & 99.7 & 99.9 & 99.9 \\
\hline $\mathrm{Mg}^{\prime}$ & & 0.68 & 0.72 & 0.75 & 0.70 & 0.69 \\
\hline \multicolumn{7}{|c|}{ Trace Elements $(\mu \mathrm{g} / \mathrm{g})$} \\
\hline \multicolumn{2}{|l|}{$\mathrm{Sc}$} & 16.4 & 14.4 & 12.5 & 16.0 & 20.7 \\
\hline \multicolumn{2}{|l|}{$\mathrm{Cr}$} & 1355 & 1313 & 1331 & 1392 & 1709 \\
\hline \multicolumn{2}{|l|}{ Co } & 16.6 & 24.5 & 27.8 & 22.1 & 29.0 \\
\hline \multicolumn{2}{|l|}{$\mathrm{Ni}$} & 71 & 128 & 176 & 124 & 210 \\
\hline \multicolumn{2}{|l|}{$\mathrm{Zn}$} & $2 !$ & 9 & 10 & 18 & 19.9 \\
\hline \multicolumn{2}{|l|}{$\mathrm{Rb}$} & 5.9 & 8.7 & 6.8 & 7.3 & 8 \\
\hline \multicolumn{2}{|l|}{$\mathrm{Sr}$} & 152 & 146 & 144 & 166 & 160 \\
\hline \multicolumn{2}{|l|}{$\mathrm{Zr}$} & 535 & 420 & 299 & 488 & 460 \\
\hline \multicolumn{2}{|l|}{$\mathrm{Cs}$} & 0.25 & 0.26 & 0.22 & 0.28 & 0.23 \\
\hline \multicolumn{2}{|l|}{$\mathrm{Ba}$} & 368 & 298 & 283 & 354 & 298 \\
\hline \multicolumn{2}{|l|}{$\mathrm{La}$} & 36.8 & 30.2 & 24.7 & 38.0 & 36.2 \\
\hline \multicolumn{2}{|l|}{$\mathrm{Ce}$} & 95.3 & 78.0 & 62.9 & 97.0 & 93.2 \\
\hline \multicolumn{2}{|l|}{$\mathrm{Nd}$} & 50.2 & 46 & 37 & 58 & 54 \\
\hline \multicolumn{2}{|l|}{$\mathrm{Sm}$} & 16.5 & 13.8 & 10.8 & 16.8 & 16.9 \\
\hline \multicolumn{2}{|l|}{$\mathrm{Eu}$} & I. 39 & 1.44 & 1.35 & 1.53 & 1.65 \\
\hline \multicolumn{2}{|l|}{$T b$} & 3.38 & 2.77 & 2.15 & 3.33 & 3.33 \\
\hline \multicolumn{2}{|l|}{$\mathrm{Yb}$} & 12.1 & 9.56 & 7.84 & 11.7 & 11.3 \\
\hline \multicolumn{2}{|l|}{ Lu } & 1.68 & 1.31 & 1.07 & 1.60 & 1.53 \\
\hline Iff & & 13.3 & 10.4 & 8.1 & 12.4 & 11.2 \\
\hline Ta & & 1.6 & 1.2 & 0.9 & 1.5 & 1.4 \\
\hline $\operatorname{Ir}(\mathrm{ng} / \mathrm{g}$ & & $<1 \mathrm{I}$ & 3.6 & 5.1 & 3.4 & 4.0 \\
\hline Au (ng/ & & $<7$ & 3.0 & 2.9 & 1.6 & 2.5 \\
\hline Th & & 6.8 & 4.8 & 4.0 & 5.8 & 5.3 \\
\hline U & & 2.0 & 1.3 & I.I & 1.6 & 1.5 \\
\hline Sample & mount & fbo & ts8B & ts9D & $\operatorname{ts} 10 \mathrm{~A}$ & ts $15 \mathrm{C}$ \\
\hline$I N \wedge A$ & & 274.108 & 280.042 & 282.003 & 282.005 & 287.136 \\
\hline
\end{tabular}

ts $=$ thin section (mount $\#$ ); fbo = fused

bead only; --- = no value

$\mathrm{Mg}^{\prime}=$ molar $\mathrm{MgO} /(\mathrm{MgO}+\mathrm{FeO})$
TABLE A3d. Other impact-melt breccias.

\begin{tabular}{|c|c|c|c|c|c|c|c|c|}
\hline $\begin{array}{l}76503 \\
, 7003\end{array}$ & $\begin{array}{l}76503 \\
, 7058^{1}\end{array}$ & $\begin{array}{l}76503 \\
, 7139\end{array}$ & $\begin{array}{l}36503 \\
\quad, 7175\end{array}$ & $\begin{array}{r}76503 \\
, 7025^{2}\end{array}$ & $\begin{array}{l}76503 \\
, 7190\end{array}$ & $\begin{array}{l}72503 \\
, 7102\end{array}$ & $\begin{array}{l}72503 \\
, 7123^{3}\end{array}$ & $\begin{array}{l}72443 \\
, 7046^{4}\end{array}$ \\
\hline 28.56 & 24.94 & 14.82 & 9.00 & 10.94 & 13.06 & 70.99 & 30.95 & 28.71 \\
\hline \multicolumn{9}{|c|}{ Major-element Oxides } \\
\hline 45.8 & 45.5 & 46.6 & 46.6 & 52.3 & 45.3 & 46.9 & 43.8 & 46.9 \\
\hline 0.33 & 1.09 & 1.28 & 1.04 & 0.60 & 0.88 & 0.84 & 0.34 & 0.90 \\
\hline 23.9 & 24.3 & 17.4 & 19.3 & 21.1 & 16.1 & 18.1 & 23.1 & 14.0 \\
\hline 0.19 & 0.12 & 0.21 & 0.18 & 0.15 & 0.20 & 0.23 & 0.54 & 0.20 \\
\hline 0.18 & 0.10 & 0.22 & 0.18 & 0.12 & 0.19 & 0.26 & 0.20 & 0.20 \\
\hline 6.77 & 6.92 & 8.43 & 7.32 & 7.76 & 8.02 & 9.30 & 5.52 & 11.7 \\
\hline 6.47 & 6.60 & 7.59 & 7.13 & 6.15 & 7.68 & 9.11 & 5.21 & 11.3 \\
\hline 0.10 & 0.09 & 0.12 & 0.11 & 0.08 & 0.10 & 0.14 & 0.07 & 0.15 \\
\hline 8.63 & 7.90 & 15.1 & 13.8 & 3.87 & 19.0 & 11.7 & 14.0 & 16.0 \\
\hline 13.5 & 13.4 & 10.3 & 11.4 & 11.4 & 9.62 & 11.7 & 11.7 & 10.3 \\
\hline 13.7 & I4.1 & 10.8 & 11.0 & 12.4 & 9.79 & 11.7 & 12.6 & 9.83 \\
\hline 0.53 & 0.62 & 0.53 & 0.60 & 0.64 & 0.46 & 0.57 & 0.36 & 0.79 \\
\hline 0.50 & 0.61 & 0.51 & 0.57 & 0.56 & 0.42 & 0.58 & 0.36 & 0.75 \\
\hline 0.21 & 0.30 & 0.17 & 0.20 & 1.61 & 0.15 & 0.20 & 0.10 & 0.22 \\
\hline 0.05 & 0.19 & 0.11 & 0.15 & 0.14 & 0.15 & 0.08 & 0.10 & 0.07 \\
\hline 99.9 & 100.7 & 99.9 & 100.0 & 98.9 & 99.8 & 99.7 & 99.9 & 100.3 \\
\hline 0.70 & 0.68 & 0.78 & 0.77 & 0.53 & 0.81 & 0.70 & 0.83 & 0.72 \\
\hline \multicolumn{9}{|c|}{ Trace Elements $(\mu \mathrm{g} / \mathrm{g})$} \\
\hline 13.5 & 11.0 & 15.2 & 13.0 & 16.5 & 12.0 & 19.5 & 7.30 & 18.8 \\
\hline 1335 & 815 & 1428 & 1199 & 1000 & 1351 & 1551 & 3720 & 1352 \\
\hline 30.0 & 29.7 & 21.9 & 11.0 & 17.7 & 47.0 & 33.2 & 26.9 & 25.6 \\
\hline 259 & 369 & 173 & 72 & 34 & 487 & 290 & 97 & 52 \\
\hline$<19$ & 9 & 18 & 14 & 20 & 13 & - & 11 & 12 \\
\hline 8.4 & 8.0 & 6.7 & 6.7 & 78.1 & 5.3 & 7.6 & 4.5 & 9.5 \\
\hline 137 & 182 & 147 & 142 & 165 & 141 & 150 & 113 & 144 \\
\hline 107 & 427 & 347 & 331 & 635 & 264 & 260 & 159 & 106 \\
\hline 0.41 & 0.37 & 0.25 & 0.25 & 3.31 & 0.20 & 0.15 & 0.14 & 0.297 \\
\hline 130 & 314 & 270 & 243 & 699 & 203 & 220 & 199 & 98 \\
\hline 8.21 & 30.0 & 25.3 & 22.1 & 45.7 & 18.9 & 19.3 & 16.2 & 7.77 \\
\hline 20.9 & 76.9 & 65.2 & 57.5 & 117 & 48.9 & 49.6 & 40.6 & 20.6 \\
\hline 14 & 46.5 & 38.1 & 31.7 & 65.6 & 27.8 & 29 & 22 & 13.1 \\
\hline 3.51 & 13.7 & 11.7 & 10.1 & 19.2 & 8.64 & 8.80 & 6.83 & 4.11 \\
\hline 0.88 & 1.72 & 1.57 & 1.49 & 1.55 & 1.25 & 1.60 & 1.20 & 1.30 \\
\hline 0.79 & 2.71 & 2.39 & 2.05 & 4.17 & 1.75 & 1.72 & 1.27 & 0.89 \\
\hline 3.81 & 8.87 & 8.47 & 7.37 & 19.3 & 6.36 & 6.57 & 4.75 & 3.2 \\
\hline 0.52 & 1.19 & 1.16 & 1.03 & 2.68 & 0.88 & 0.90 & 0.66 & 0.46 \\
\hline 3.1 & 10.5 & 9.2 & 8.1 & 17.4 & 6.9 & 6.6 & 4.2 & 2.9 \\
\hline 0.5 & 1.3 & 1.2 & 1.1 & 2.5 & 0.9 & 0.8 & 0.5 & 0.36 \\
\hline 12.3 & 13 & 4.2 & $<10$ & $<5$ & 9.8 & 7.0 & 3.6 & $<1.6$ \\
\hline$<6$ & 4.2 & $<9$ & $<11$ & $<4$ & 6.1 & 4.6 & $<3$ & $<1.7$ \\
\hline 2.6 & 4.8 & 4.1 & 3.7 & 14.5 & 3.1 & 2.8 & 2.2 & 0.9 \\
\hline 0.8 & 1.2 & 1.2 & 1.1 & 4.3 & 0.9 & 0.8 & 0.7 & 0.24 \\
\hline ts $19 \mathrm{~A}$ & ts $1 \mathrm{C}$ & fbo & fbo & ts IB & fbo & ts $9 B$ & tsliB & ts $14 \mathrm{C}$ \\
\hline 273.003 & 273.114 & 274.045 & 274.131 & 273.025 & 274.146 & 282.001 & 282.022 & 287,123 \\
\hline
\end{tabular}


TABLE A4. Regolith breccias.

\begin{tabular}{|c|c|c|c|c|c|c|c|c|c|c|c|c|c|}
\hline \multicolumn{2}{|l|}{ Sample } & $\begin{array}{l}72503 \\
, 7044\end{array}$ & $\begin{array}{l}76503 \\
, 7047\end{array}$ & $\begin{array}{l}76503 \\
, 7129\end{array}$ & $\begin{array}{l}76503 \\
, 7219\end{array}$ & $\begin{array}{l}72503 \\
, 7016\end{array}$ & $\begin{array}{l}76503 \\
, 7020^{*}\end{array}$ & $\begin{array}{l}76503 \\
, 7027\end{array}$ & $\begin{array}{l}76503 \\
, 7033\end{array}$ & $\begin{array}{l}76503 \\
, 7107\end{array}$ & $\begin{array}{l}76503 \\
, 7114\end{array}$ & $\begin{array}{l}76503 \\
, 7173\end{array}$ & $\begin{array}{l}76503 \\
, 7176\end{array}$ \\
\hline \multicolumn{2}{|c|}{ Description } & $\begin{array}{l}\text { RBx- } \\
\text { Aggl }\end{array}$ & $\begin{array}{l}\text { clastic } \\
\text { matrix }\end{array}$ & $\begin{array}{l}\mathrm{Br} \text { Gls } \\
\text { matrix }\end{array}$ & $\begin{array}{l}\text { RBx- } \\
\text { Aggl }\end{array}$ & $\begin{array}{l}\mathrm{BrGls} \\
\text { matrix }\end{array}$ & AggI & $\begin{array}{c}\text { dark } \\
\text { matrix }\end{array}$ & $\begin{array}{l}\text { Br Gls } \\
\text { matrix }\end{array}$ & $\underset{\text { matrix }}{\text { gray }}$ & $\begin{array}{c}\text { dark } \\
\text { matrix }\end{array}$ & $\begin{array}{l}\text { RBx- } \\
\text { Aggl }\end{array}$ & $\begin{array}{c}\text { dark } \\
\text { matrix }\end{array}$ \\
\hline \multicolumn{2}{|c|}{ Mass (mg) } & 28.41 & 16.90 & 21.11 & 51.51 & 24.92 & 15.53 & 15.89 & 20.57 & 6.71 & 13.17 & 8.64 & 8.62 \\
\hline \multicolumn{14}{|c|}{ Major-element Oxides } \\
\hline $\mathrm{SiO}_{2}$ & $\mathrm{FB}$ & 46.0 & 44.5 & 45.0 & 45.1 & 45.2 & 43.4 & 42.0 & 43.9 & 43.8 & 45.2 & 45.1 & 44.3 \\
\hline $\mathrm{TiO}_{2}$ & FB & 0.57 & 0.49 & 0.56 & 0.50 & 1.62 & 1.40 & 6.40 & 4.09 & 3.47 & 2.59 & 1.56 & 3.17 \\
\hline $\mathrm{Al}_{2} \mathrm{O}_{3}$ & FB & 22.3 & 27.5 & 22.3 & 22.0 & 21.7 & 20.9 & 14.9 & 16.3 & 18.1 & 19.1 & 21.0 & 18.5 \\
\hline $\mathrm{Cr}_{2} \mathrm{O}_{3}$ & INAA & 0.20 & 0.08 & 0.14 & 0.15 & 0.22 & 0.20 & 0.37 & 0.30 & 0.27 & 0.28 & 0.21 & 0.28 \\
\hline $\mathrm{Cr}_{2} \mathrm{O}_{3}$ & FB & 0.20 & 0.10 & 0.17 & 0.14 & 0.20 & 0.19 & 0.37 & 0.31 & 0.29 & 0.27 & 0.19 & 0.27 \\
\hline $\mathrm{FeO}$ & INAA & 7.32 & 4.03 & 5.50 & 6.89 & 8.53 & 8.70 & 14.3 & 12.7 & 10.7 & 10.8 & 8.31 & 11.0 \\
\hline $\mathrm{FeO}$ & FB & 6.84 & 4.22 & 5.62 & 5.79 & 7.80 & 7.90 & 13.9 & 12.5 & 10.4 & 10.1 & 7.73 & 10.0 \\
\hline $\mathrm{MnO}$ & FB & 0.07 & 0.07 & 0.07 & 0.08 & 0.11 & 0.10 & 0.18 & 0.16 & 0.15 & 0.11 & 0.09 & 0.12 \\
\hline $\mathrm{MgO}$ & FB & 11.1 & 6.02 & 13.5 & 13.7 & 9.84 & 12.7 & 9.99 & 9.34 & 11.5 & 10.1 & 12.0 & 11.1 \\
\hline $\mathrm{CaO}$ & INAA & 12.6 & 15.9 & 12.4 & 11.8 & 12.6 & 12.7 & 11.5 & 12.0 & 11.4 & 12.4 & 12.6 & 12.4 \\
\hline $\mathrm{CaO}$ & FB & 12.8 & 15.8 & 12.7 & 12.5 & 12.9 & 12.6 & 11.4 & 11.8 & 12.0 & 12.0 & 12.2 & 11.7 \\
\hline $\mathrm{Na}_{2} \mathrm{O}$ & INAA & 0.39 & 0.46 & 0.45 & 0.41 & 0.46 & 0.35 & 0.40 & 0.77 & 0.39 & 0.52 & 0.37 & 0.39 \\
\hline $\mathrm{Na}_{2} \mathrm{O}$ & FB & 0.37 & 0.44 & 0.43 & 0.34 & 0.42 & 0.28 & 0.38 & 0.75 & 0.36 & 0.52 & 0.33 & 0.37 \\
\hline $\mathrm{K}_{2} \mathrm{O}$ & FB & 0.16 & 0.11 & 0.12 & 0.11 & 0.15 & 0.08 & 0.09 & 0.09 & 0.08 & 0.16 & 0.10 & 0.10 \\
\hline $\mathrm{P}_{2} \mathrm{O}_{5}$ & FB & 0.07 & 0.12 & 0.08 & 0.04 & 0.08 & 0.08 & 0.05 & 0.07 & 0.05 & 0.08 & 0.04 & 0.04 \\
\hline Total & (FB) & 100.4 & 99.4 & 100.1 & 100.4 & 100.0 & 99.5 & 99.7 & 99.2 & 100.1 & 100.3 & 100.4 & 99.7 \\
\hline $\mathrm{Mg}^{\prime}$ & & 0.74 & 0.72 & 0.81 & 0.81 & 0.69 & 0.74 & 0.56 & 0.57 & 0.66 & 0.64 & 0.73 & 0.66 \\
\hline \multicolumn{14}{|c|}{ Trace Elements $(\mu \mathrm{g} / \mathrm{g})$} \\
\hline & 12.5 & 6.58 & 8.39 & 10.0 & 18.4 & 15.2 & 45.8 & 30.0 & 29.4 & 22.8 & 17.8 & 28.2 \\
\hline \multicolumn{2}{|l|}{$\mathrm{Cr}$} & 1344 & 533 & 985 & 1055 & 1502 & 1348 & 2544 & 2069 & 1881 & 1922 & 1457 & 1908 \\
\hline \multicolumn{2}{|l|}{$\mathrm{Co}$} & 34.2 & 21.7 & 20.1 & 42.7 & 28.3 & 36.6 & 32.2 & 31.3 & 31.6 & 34.9 & 29.8 & 37.8 \\
\hline \multicolumn{2}{|l|}{$\mathrm{Ni}$} & 400 & 288 & 113 & 242 & 240 & 316 & 230 & 134 & 140 & 267 & 211 & 388 \\
\hline \multicolumn{2}{|l|}{$\mathrm{Zn}$} & 10 & 7 & 7 & 11 & 21 & 24 & 31 & 100 & 62 & 57 & 31 & 47 \\
\hline \multicolumn{2}{|l|}{$\mathrm{Rb}$} & 6.2 & 2.6 & 5.8 & 6.7 & 8.0 & 4.9 & $<30$ & $<12$ & $<13$ & 8.5 & $<10$ & 4.6 \\
\hline \multicolumn{2}{|l|}{$\mathrm{Sr}$} & 145 & 170 & 177 & 149 & 170 & 129 & 200 & 190 & 90 & 178 & 144 & 170 \\
\hline \multicolumn{2}{|l|}{$\mathrm{Zr}$} & 163 & 175 & 409 & 163 & 270 & 347 & 210 & 160 & $<200$ & 247 & 143 & 168 \\
\hline \multicolumn{2}{|l|}{ Cs } & 0.20 & 0.18 & 0.13 & 0.22 & 0.18 & 0.11 & $<0.8$ & $<0.4$ & $<0.5$ & 0.24 & 0.13 & 0.12 \\
\hline \multicolumn{2}{|l|}{$\underline{\mathrm{Ba}}$} & 142 & 123 & 126 & 145 & 197 & 122 & 140 & 112 & 94. & 194 & 115 & 123 \\
\hline \multicolumn{2}{|l|}{$\mathrm{La}$} & 11.4 & 12.0 & 11.1 & 11.7 & 17.2 & 14.3 & 8.57 & 8.44 & 7.33 & 15.9 & 8.99 & 9.66 \\
\hline \multicolumn{2}{|l|}{$\mathrm{Ce}$} & 30.1 & 31.6 & 28.3 & 30.3 & 45.2 & 48.2 & 23.3 & 23.6 & 20.5 & 42.0 & 23.8 & 26.2 \\
\hline \multicolumn{2}{|l|}{$\mathrm{Nd}$} & 16.6 & 18.7 & 16.0 & 18.3 & 26 & 31.4 & 19.0 & 13.3 & 15.0 & 29.0 & 13.7 & 16.6 \\
\hline $\mathrm{Sm}$ & & 5.19 & 5.53 & 5.04 & 5.24 & 8.38 & 11.63 & 6.95 & 5.63 & 5.20 & 8.04 & 4.58 & 5.86 \\
\hline $\mathrm{Eu}$ & & 1.04 & 1.08 & 1.19 & 1.11 & 1.35 & 1.11 & 1.45 & 1.62 & 1.23 & 1.55 & 1.10 & 1.26 \\
\hline $\mathrm{Tb}$ & & 1.08 & 1.11 & 1.06 & 1.10 & 1.75 & 3.37 & 1.62 & 1.27 & 1.24 & 1.69 & 1.04 & 1.33 \\
\hline $\mathrm{Yb}$ & & 4.14 & 3.92 & 4.25 & 4.36 & 6.14 & 19.9 & 5.87 & 4.23 & 4.27 & 5.95 & 3.67 & 4.89 \\
\hline Lu & & 0.58 & 0.52 & 0.60 & 0.60 & 0.85 & 2.37 & 0.85 & 0.60 & 0.59 & 0.82 & 0.50 & 0.69 \\
\hline $\mathrm{Hf}$ & & 4.0 & 4.2 & 10.0 & 4.2 & 6.8 & 10 & 6.3 & 4.6 & 4.4 & 6.6 & 3.8 & 4.8 \\
\hline $\mathrm{Ta}$ & & 0.6 & 0.5 & 0.5 & 0.6 & 0.9 & 5.8 & 0.9 & 0.7 & 0.7 & 0.9 & 0.5 & 0.8 \\
\hline $\mathrm{Ir}$ (ng/g & & 14 & 8.9 & 2.3 & 5.6 & 7.0 & 14 & $<19$ & 5.3 & $<11$ & 13 & 6.0 & 18 \\
\hline Au (ng & & 5.9 & 7.1 & $<6$ & 2.6 & 3.3 & 3.4 & $<10$ & $<12$ & $<7$ & 4.4 & 2.3 & 3.2 \\
\hline Th & & 2.2 & 2.0 & 2.0 & 2.3 & 3.0 & 37 & 1.1 & 1.1 & 1.2 & 2.6 & 1.4 & 1.6 \\
\hline $\mathrm{U}$ & & 0.6 & 0.6 & 0.6 & 0.6 & 0.9 & 10 & $<1.2$ & 0.27 & 0.33 & 0.8 & 0.4 & 0.41 \\
\hline Sample & lount & $\operatorname{ts} 17 \mathrm{~A}$ & ts $4 \mathrm{~A}$ & ts $5 \mathrm{D}$ & $\mathrm{ts} 21 \mathrm{D}$ & ts $7 \mathrm{D}$ & $\mathrm{ts} 1 \mathrm{~A}$ & fbo & ts $5 \Lambda$ & fbo & fbo & fbo & fbo \\
\hline INAA & & 280.044 & 273.103 & 274.035 & 277.025 & 280.016 & 273.020 & 273.027 & 273.033 & 274.013 & 274.020 & 274.129 & 274.132 \\
\hline
\end{tabular}

ts $=$ thin section (mount $H$ ); bo $=$ fused bead only

$\mathrm{Mg}^{\mathrm{t}}=$ molar $\mathrm{MgO} /(\mathrm{MgO}+\mathrm{FeO})$

* Major-element composition of 76503,7020 measured by EMP of agglutinate glass.

Samples in the first four columns are essentially free of mare components.

$\mathrm{Br}$ Gls = brown, glassy matrix, based on observation of thin section; $\mathrm{Aggl}=$ agglutinate; $\mathrm{RBx}-\mathrm{Aggl}=$ composite regolith $\mathrm{Bx} / \mathrm{Aggl}$. 
TABLE A5. Basaltic and orange-glass fragments.

\begin{tabular}{|c|c|c|c|c|c|c|c|c|c|c|c|}
\hline \multirow{2}{*}{ Sample } & & \multicolumn{6}{|c|}{ Basaltic Fragments } & \multicolumn{4}{|c|}{ Orange Glass } \\
\hline & & $\begin{array}{l}76503 \\
, 7101\end{array}$ & $\begin{array}{l}76503 \\
, 7134\end{array}$ & $\begin{array}{l}76503 \\
, 7137\end{array}$ & $\begin{array}{l}76503 \\
, 7014\end{array}$ & $\begin{array}{c}76503^{*} \\
, 7012\end{array}$ & $\begin{array}{l}76503 \\
, 7040\end{array}$ & $\begin{array}{l}76503 \\
, 7024\end{array}$ & $\begin{array}{l}76503 \\
, 7043\end{array}$ & $\begin{array}{l}76503 \\
, 7178\end{array}$ & $\begin{array}{r}76503 \\
, 7188\end{array}$ \\
\hline \multicolumn{2}{|c|}{ Description } & $\begin{array}{l}\text { Ilm Bas } \\
\text { coarse }\end{array}$ & $\begin{array}{l}\text { Ilm Bas } \\
\text { coarse }\end{array}$ & $\begin{array}{l}\text { Ilm Bas } \\
\text { fine }\end{array}$ & $\begin{array}{c}\text { Mbas } \\
\mathrm{Bx}\end{array}$ & $\begin{array}{l}\text { Mbas } B x / \\
\text { vitrophyre }\end{array}$ & $\begin{array}{l}\text { VLT } \\
\text { Bas }\end{array}$ & $\begin{array}{l}\text { Vitro- } \\
\text { phyre }\end{array}$ & $\begin{array}{l}\text { Reg } \\
\mathrm{Bx}\end{array}$ & $\underset{B x}{\operatorname{Reg}}$ & $\begin{array}{c}\text { Reg Bx- } \\
\text { Agglut }\end{array}$ \\
\hline \multicolumn{2}{|c|}{ Mass (mg) } & 30.15 & 9.89 & 7.91 & 13.40 & 23.50 & 18.28 & 24.59 & 21.07 & 9.95 & 11.53 \\
\hline \multicolumn{12}{|c|}{ Major-element Oxides } \\
\hline $\mathrm{SiO}_{2}$ & FB & 38.1 & 39.8 & 38.9 & 41.6 & 43.58 & 48.4 & 38.3 & 40.4 & 38.4 & 39.6 \\
\hline $\mathrm{TiO}_{2}$ & FB & 12.1 & 11.1 & 13.3 & 8.13 & 5.83 & 0.68 & 8.65 & 7.94 & 8.94 & 8.26 \\
\hline $\mathrm{Al}_{2} \mathrm{O}_{3}$ & FB & 10.0 & 12.3 & 10.1 & 13.1 & 12.0 & 15.5 & 5.69 & 9.16 & 6.12 & 7.86 \\
\hline $\mathrm{Cr}_{2} \mathrm{O}_{3}$ & INAA & 0.63 & 0.49 & 0.61 & 0.38 & 0.51 & 0.40 & 0.69 & 0.58 & 0.71 & 0.65 \\
\hline $\mathrm{Cr}_{2} \mathrm{O}_{3}$ & $\mathrm{FB}$ & 0.58 & 0.49 & 0.60 & 0.42 & 0.49 & 0.40 & 0.71 & 0.60 & 0.72 & 0.64 \\
\hline $\mathrm{FeO}$ & INAA & 17.8 & 16.3 & 19.7 & 15.6 & 17.9 & 12.1 & 23.2 & 19.8 & 23.3 & 21.6 \\
\hline $\mathrm{FeO}$ & $\mathrm{FB}$ & 17.1 & 15.8 & 19.3 & 15.2 & 17.8 & 10.5 & 22.5 & 19.5 & 22.4 & 21.0 \\
\hline $\mathrm{MnO}$ & FB & 0.23 & 0.21 & 0.26 & 0.22 & 0.25 & 0.18 & 0.29 & 0.24 & 0.27 & 0.24 \\
\hline $\mathrm{MgO}$ & $\mathrm{FB}$ & 10.7 & 9.62 & 5.74 & 8.37 & 8.65 & 8.43 & 15.0 & 12.6 & 15.0 & 13.7 \\
\hline $\mathrm{CaO}$ & INAA & 10.5 & 10.7 & 11.2 & 11.4 & 11.4 & 13.1 & 6.6 & 8.9 & 7.7 & 8.4 \\
\hline $\mathrm{CaO}$ & FB & 9.93 & 10.5 & 11.3 & [1.8 & 11.3 & 13.8 & 7.12 & 9.02 & 7.43 & 8.27 \\
\hline $\mathrm{Na}_{2} \mathrm{O}$ & INAA & 0.41 & 0.50 & 0.45 & 0.54 & 0.32 & 0.38 & 0.41 & 0.64 & 0.42 & 0.46 \\
\hline $\mathrm{Na}_{2} \mathrm{O}$ & $\mathrm{FB}$ & 0.40 & 0.49 & 0.45 & 0.51 & 0.31 & 0.40 & 0.38 & 0.63 & 0.38 & 0.45 \\
\hline $\mathrm{K}_{2} \mathrm{O}$ & $\mathrm{FB}$ & 0.02 & 0.02 & 0.06 & 0.10 & 0.05 & 0.79 & 0.07 & 0.11 & 0.07 & 0.08 \\
\hline $\mathrm{P}_{2} \mathrm{O}_{5}$ & $\mathrm{FB}$ & 0.02 & 0.02 & 0.11 & 0.06 & 0.04 & 0.05 & 0.03 & 0.05 & 0.04 & 0.03 \\
\hline Total & $(\mathrm{FB})$ & 99.3 & 100.4 & 100.1 & 99.5 & 100.3 & 99.0 & 98.8 & 100.3 & 99.7 & 100.1 \\
\hline $\mathrm{Mg}^{\prime}$ & & 0.53 & 0.52 & 0.35 & 0.50 & 0.46 & 0.59 & 0.54 & 0.54 & 0.54 & 0.54 \\
\hline \multicolumn{12}{|c|}{ Trace Elements $(\mu \mathrm{g} / \mathrm{g})$} \\
\hline \multicolumn{2}{|l|}{ Sc } & 72.9 & 68.2 & 88.8 & 62.8 & 68.2 & 61.8 & 44.8 & 48.5 & 47.2 & 45.7 \\
\hline \multicolumn{2}{|l|}{$\mathrm{Cr}$} & 4326 & 3321 & 4183 & 2570 & 3470 & 2764 & 4755 & 3967 & 4824 & 4453 \\
\hline \multicolumn{2}{|l|}{$\mathrm{Co}$} & 22.2 & 19.4 & 20.6 & 26.0 & 27.1 & 37.0 & 95 & 54 & 67 & 61 \\
\hline \multicolumn{2}{|l|}{$\mathrm{Ni}$} & $<70$ & $<130$ & $<190$ & $<300$ & $<180$ & 260 & 790 & 180 & 110 & $<260$ \\
\hline \multicolumn{2}{|l|}{$\mathrm{Zn}$} & -- & -- & -- & 196 & - & - & 59 & 322 & 297 & 319 \\
\hline \multicolumn{2}{|l|}{$\mathrm{Rb}$} & 5.3 & $<12$ & $<18$ & $<30$ & $<30$ & 31 & $<12$ & $<17$ & $<16$ & $<30$ \\
\hline \multicolumn{2}{|l|}{$\mathrm{Sr}$} & 118 & 160 & 190 & $<400$ & $<400$ & $<170$ & 179 & 230 & 180 & 260 \\
\hline \multicolumn{2}{|l|}{$\mathrm{Zr}$} & 78 & $<300$ & 230 & $<600$ & 150 & $<300$ & 156 & 230 & 180 & 190 \\
\hline \multicolumn{2}{|l|}{$\mathrm{Cs}$} & $<0.2$ & $<0.4$ & $<0.7$ & $<0.7$ & $<0.6$ & 1.48 & $<0.2$ & 0.16 & $<0.4$ & 0.30 \\
\hline \multicolumn{2}{|l|}{$\mathrm{Ba}$} & $<120$ & $<70$ & 76 & 88 & 77 & 264 & 60 & 114 & 93 & 84 \\
\hline \multicolumn{2}{|l|}{$\mathrm{La}$} & 1.14 & 0.97 & 7.17 & 8.58 & 4.87 & 2.18 & 5.53 & 8.16 & 6.00 & 6.37 \\
\hline \multicolumn{2}{|l|}{$\mathrm{Ce}$} & 4.1 & 4.2 & 22.0 & 23.9 & 15.3 & 6.4 & 16.8 & 23.2 & 19.0 & 20.0 \\
\hline $\mathrm{Nd}$ & & $<30$ & $<20$ & 22.0 & 16.0 & 10 & $<15$ & 15.0 & 26.0 & 14.6 & 19.0 \\
\hline $\mathrm{Sm}$ & & 2.19 & 2.11 & 8.87 & 9.01 & 5.79 & 1.36 & 6.26 & 7.64 & 6.69 & 6.60 \\
\hline $\mathrm{Eu}$ & & 1.11 & 1.33 & 1.70 & 1.71 & 1.15 & 0.57 & 1.74 & 1.79 & 1.85 & 1.78 \\
\hline $\mathrm{Tb}$ & & 0.71 & 0.66 & 2.27 & 2.19 & 1.50 & 0.37 & 1.35 & 1.67 & 1.53 & 1.50 \\
\hline $\mathrm{Yb}$ & & 3.40 & 3.23 & 8.88 & 7.95 & 5.47 & 2.09 & 3.88 & 5.51 & 4. 14 & 4.22 \\
\hline $\mathrm{Lu}$ & & 0.50 & 0.47 & 1.21 & 1.12 & 0.78 & 0.30 & 0.52 & 0.74 & 0.56 & 0.59 \\
\hline $\mathrm{Hf}$ & & 3.7 & 3.3 & 8.0 & 8.1 & 5.0 & 0.8 & 5.4 & 6.7 & 5.9 & 6.0 \\
\hline $\mathrm{Ta}$ & & 0.9 & 0.9 & 1.8 & 1.3 & 0.8 & $<0.3$ & 1.0 & 1.1 & 1.1 & 1.0 \\
\hline $\operatorname{Ir}(\mathrm{ng} / \mathrm{g})$ & & $<10$ & $<13$ & $<40$ & $<30$ & $<16$ & $<8$ & 33 & $<11$ & $<14$ & $<15$ \\
\hline $\mathrm{Au}$ (ng/ & & $<19$ & $<11$ & $<12$ & $<13$ & $<8$ & $<6$ & 7.3 & $<12$ & $<12$ & $<7$ \\
\hline Th & & $<0.1$ & $<0.3$ & 0.4 & 0.9 & 0.35 & 0.2 & 0.4 & 1.1 & 0.4 & 0.5 \\
\hline U & & $<0.9$ & $<0.7$ & $<1.7$ & 0.3 & $<0.4$ & $<0.7$ & $<0.6$ & $<1.5$ & $<1.5$ & $<1.5$ \\
\hline Sample & ount & ts6A & fbo & fbo & fbo & ts 19D & ts $6 \mathrm{~B}$ & $\mathrm{ts} 2 \mathrm{~A}$ & $\mathrm{ts} 2 \mathrm{~B}$ & fbo & fbo \\
\hline INAA \# & & 274.007 & 274.04 & 274.043 & 273.014 & 273.012 & 273.040 & 273.024 & 273.043 & 274.134 & 274.144 \\
\hline
\end{tabular}

ts = thin section (mount \#); fbo = fused bead only.

-.. = no value.

$\mathrm{Mg}^{\prime}=\mathrm{molar} \mathrm{MgO} /(\mathrm{MgO}+\mathrm{FeO})$.

* Major-element analysis of 76503,7012 by electron microprobe of glass.

$\mathrm{IIm}=$ ilmenite; Bas = basalt; $\mathrm{Bx}=$ breccia; Mbas = mare basalt; Reg = regolith; VLT = very-low-Ti;

Agglut = agglutinate; coarse $=0.1 \mathrm{~mm}-1.2 \mathrm{~mm}$ grain size; fine $=$ grain size $<0.2 \mathrm{~mm}$. 
